\title{
Distribution of adenosine deaminase complexing protein in normal and neoplastic cells
}

Citation for published version (APA):

Dinjens, W. N. M. (1988). Distribution of adenosine deaminase complexing protein in normal and neoplastic cells. [Doctoral Thesis, Maastricht University]. Rijksuniversiteit Limburg. https://doi.org/10.26481/dis.19881215wd

Document status and date:

Published: 01/01/1988

DOI:

10.26481/dis.19881215wd

Document Version:

Publisher's PDF, also known as Version of record

\section{Please check the document version of this publication:}

- A submitted manuscript is the version of the article upon submission and before peer-review. There can be important differences between the submitted version and the official published version of record. People interested in the research are advised to contact the author for the final version of the publication, or visit the DOI to the publisher's website.

- The final author version and the galley proof are versions of the publication after peer review.

- The final published version features the final layout of the paper including the volume, issue and page numbers.

Link to publication

\footnotetext{
General rights rights.

- You may freely distribute the URL identifying the publication in the public portal. please follow below link for the End User Agreement:

www.umlib.nl/taverne-license

Take down policy

If you believe that this document breaches copyright please contact us at:

repository@maastrichtuniversity.nl

providing details and we will investigate your claim.
}

Copyright and moral rights for the publications made accessible in the public portal are retained by the authors and/or other copyright owners and it is a condition of accessing publications that users recognise and abide by the legal requirements associated with these

- Users may download and print one copy of any publication from the public portal for the purpose of private study or research.

- You may not further distribute the material or use it for any profit-making activity or commercial gain

If the publication is distributed under the terms of Article $25 \mathrm{fa}$ of the Dutch Copyright Act, indicated by the "Taverne" license above, 
Het verschijnen vam dit proefschrift werd mede mogelljk gemaakt door financiële steun van de Jair Dekkerstichtirig \& Dr. Ludgardine Boumanstichting. 
Distribution of adenosine deaminase complexing protein in normal and neoplastic cells 



\section{Distribution of adenosine deaminase complexing protein in normal and neoplastic cells}

\section{Proefschrift}

ter verkrijging van de graad van doctor

aan de Rijksuniversiteit Limburg te Maastricht, op gezag van de Rector Magnificus, Prof.dr. F.I.M. Bonke, volgens het besluit van het College van Dekanen, in het openbaar te verdedigen op donderdag, 15 december 1988 om 16.00 uur

door

Winandus Nicolaas Maria Dinjens geboren te Maastricht in 1956 
Promotores:

Prof.dr. F.T. Bosman

Prof.dr. P. Meera Khan (Rijksuniversiteit Leiden)

Co-promotor: Dr. J.ten Kate

Beoordelingscommissie: Prof.dr. G.H. Blijham, voorzitter

Prof.dr. F. ten Hoor

Prof.dr. J. Drukker

Prof.dr. C.H.M.M. De Bruijn (Technische Universiteit

Eindhoven)

Prof.dr. D.J. Ruiter (Katholieke Universiteit Nijmegen)

The work described in this thesis was performed as a collaborative research project of the Department of Pathology, University of Limburg (Prof.dr. F.T. Bosman) and the Section Enzyme and Somatic Cell Genetics of the Department of Human Genetics, University of Leiden (Prof.dr. P. Meera Khan). This project was financially supported by the Netherlands Cancer Foundation "Het Koningin Wilhelmina Fonds", grant IKW 85-82.

De uitgave van dit proefschrift werd financieel ondersteund door de Stichting Bevordering Klinische Pathologie Limburg.

Zetwerk en druk: Groenevelt bv, Landgraaf

Cover: Juliëtte Dinjens 
Ter nagedachtenis aan mijn vader Aan mijn moeder

Aan Juliëtte en Bas 



\section{Contents}

List of abbreviations

$\begin{array}{lll}\text { Chapter } 1 & \text { General introduction } & 13\end{array}$

1.1 Introduction 13

1.2 Possible physiological role of ADCP 15

1.3 ADCP expression and in vitro cell transformation 16

1.4 Is there a regulatory mechanism involved in the expression $\begin{array}{ll}\text { of ADCP? } & 17\end{array}$

$\begin{array}{lll}1.5 & \text { ADCP in cancer studies } & 17\end{array}$

$\begin{array}{lll}1.6 & \text { Aims of the present study } & 18\end{array}$

1.7 References 19

Chapter 2 Solid phase adsorption of antigens for efficient production of antibodies reactive with native and fixed tissue antigens 25

2.1 Introduction 25

2.2 Materials and Methods $\quad 26$

2.2.1 Antigen purification and processing 26

2.2.2 Immunization protocols 26

2.2.3 Monoclonal antibodly production 27

2.3 Results 28

2.4 Discussion 31

2.5 References 34

Chapter 3 Distribution of adenosine deaminase complexing protein (ADCP) in murine tissues $\quad 37$

$\begin{array}{lll}3.1 & \text { Introduction } & 37\end{array}$

3.2 Materials and Methods 38

3.2.1 Immunohistochemistry 38

3.2.2 Starch gel electrophoresis 38

3.2.3 Sodium dodecyl sulphate polyacrylamide gel

3.3 Results 40

3.3.1 Immunohistochemistry $\quad 40$

3.3.2 Starch gel electrophoresis 40

3.3.3 SDS-PAGE 41 . 
Chapter 4 Distribution of adenosine deaminase complexing protein (ADCP) in human tissues

4.1 Introduction 45

4.2 Materials and Methods $\quad 46$

4.2.1 Tissue sources and antiserum 46

4.2 .2 Radioimmunoassay (RIA) $\quad 46$

4.2.3 Immunohistochemistry 46

4.3 Results $\quad 47$

$\begin{array}{lll}4.3 .1 & \text { RIA } & 47\end{array}$

4.3.2 Immunohistochemistry 48

4.4 Discussion $\quad 54$

4.5 References 56

Chapter 5 Immunocytochemical demonstration of adenosine deaminase (ADA) and adenosine deaminase complexing protein (ADCP) on human T-lymphoid cells

5.1 Introduction 59

$\begin{array}{ll}5.2 & \text { Materials and Methods }\end{array}$

$\begin{array}{lll}5.2 .1 & \text { Preparation of cell suspensions } & 60\end{array}$

$\begin{array}{ll}5.2 .2 & \text { Antisera and monoclonal antibodies }\end{array}$

5.2 .3 Flowcytometry $\quad 60$

5.2.4 Statistical evaluation 61

5.3 Results 63

5.4 Discussion 65

5.5 References 66

Chapter 6 Adenosine deaminase complexing protein (ADCP) immunoreactivity in adenocarcinomas 69

6.1 Introduction 69

6.2 Materials and Methods 69

6.2.1 Antibodies 69

$\begin{array}{lll}6.2 .2 & \text { Tissue panel } & 70\end{array}$

$\begin{array}{lll}6.2 .3 & \text { Immunohistochemistry } & 70\end{array}$

$\begin{array}{lll}6.3 & \text { Results } & 71\end{array}$

6.3.1 Reactivity in normal human tissues 71

6.3.2 Reactivity in neoplasms 71

$\begin{array}{lll}6.4 \text { Discussion } & 75\end{array}$

$\begin{array}{lll}6.5 & \text { References } & 79\end{array}$ 
Chapter 7 Adenosine deaminase complexing protein (ADCP) expression and metastatic potential in prostatic adenocarcinomas

7.1 Introduction 81

7.2 Materials and Methods 81

$\begin{array}{lll}7.3 \text { Results } & 82\end{array}$

7.4 Discussion $\quad 86$

$\begin{array}{lll}7.5 & \text { References } & 88\end{array}$

Chapter $8 \quad$ Expression of adenosine deaminase complexing protein (ADCP) in human colorectal carcinoma cell lines $\quad 89$

$\begin{array}{lll}8.1 & \text { Introduction } & 89\end{array}$

$\begin{array}{ll}8.2 \quad \text { Materials and Methods } & 90\end{array}$

8.2.1 Chemicals and antibodies 90

$\begin{array}{lll}\text { 8.2.2 Cell lines } & 90\end{array}$

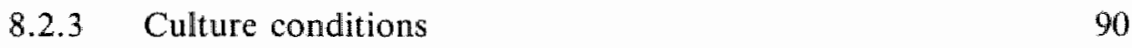

8.2.4 Tumors in nude rats 91

8.2.5 Immunocytochemistry 9l

8.2.6 Electronmicroscopy 91

8.3 Results 91

8.4 Discussion 95

8.5 References 100

$\begin{array}{lll}\text { Chapter } 9 & \text { General discussion } & 103\end{array}$

9.1 Introduction 103

9.2 Physiological function of ADCP 103

9.3 ADCP and neoplastic transformation 104

$\begin{array}{lll}9.4 & \text { Future prospectives } & 106\end{array}$

9.5 References 106

$\begin{array}{ll}\text { Summary } & 109\end{array}$

$\begin{array}{ll}\text { Samenvatting } & 113\end{array}$

$\begin{array}{ll}\text { Dankwoord } & 117\end{array}$

$\begin{array}{ll}\text { Curriculum vitae } & 119\end{array}$ 



\section{List of abbreviations}

ADA

ADA-L.

ADA-S

ADCP

BSA

$C D$

CEA

DAB

DMSO

ELISA

FCA

FIA

G/R FITC

HAT

Ig

i.p.

i.s.

i.v.

l.n.

MNC

$\mathrm{MoAb}$

$\mathrm{MW}$

$\mathrm{NaBT}$

NRS

PE

PEG

PBL-T

PBS

PBT

PLP.

PVDF

RA

RIA

RT

$\mathrm{SC}$

S.C.

SD

SDS-PAGE

SI
Adenosine deaminase

Large molecular weight form of $\mathrm{ADA}$

Small molecular weight form of ADA

Adenosine deaminase complexing protein

Bovine serum albumin

Cluster of differentiation

Carcinoembryonic antigen

Diaminobenzidine tetrahydrochloride

Dimethyl sulfoxide

Enzyme linked immunosorbent assay

Freund's complete adjuvant

Freund's incomplete adjuvant

Fluorescein isothiocyanate labeled goat anti-rabbit $\lg \mathrm{G}$

Hypoxanthine, aminopterin, thymidine

Immunoglobulins

Intraperitoneal

Intrasplenic

Intraveneous

Lymph node

Peripheral blood mononuclear cells

Monoclonal antibody

Molecular weight

Butyric acid sodium salt.

Normal rabbit serum

Phycoerythrin

Polyethylene glycol

Peripheral blood $\mathrm{T}$ lymphocytes

Phosphate buffered salline

PBS + 0.05\% (v/v) Tween 20

Periodate-L-lysine-paratormaldehyde

Polyvinylidene difluoride

Retinoic acid

Radioimmunoassay

Room temperature

Secretory component

Subcutaneous

Standard deviation

Sodium dodecyl sulphate polyacrylamide gel electrophoresis

Sucrase-isomaltase 



\section{Chapter 1}

\section{General introduction*}

\subsection{Introduction}

The adenosine deaminase complexing protein (ADCP) $(1,2)$ was first described by Nishihara et al. (3) as a conversion factor with the capacity to convert the small molecular form of the enzyme adenosine deaminase (ADA-S) into a large form (ADA-L).

ADCP is a dimeric glycoprotein consisting of two identical subunits of about 110 $\mathrm{kD}$ each (4-9). In some studies a subunit of about $70 \mathrm{kD}$ in addition to the $110 \mathrm{kD}$ subunit has been described. This subunit has been regarded as a degradation product (10), as a non-glycosylated form (11) and recently as a substantive mature subunit (12). One molecule of ADCP has the capacity to bind two molecules of ADA-S, both of $43 \mathrm{kD}$, forming one ADA-L molecule of about $280 \mathrm{kD}$ (Fig. 1)
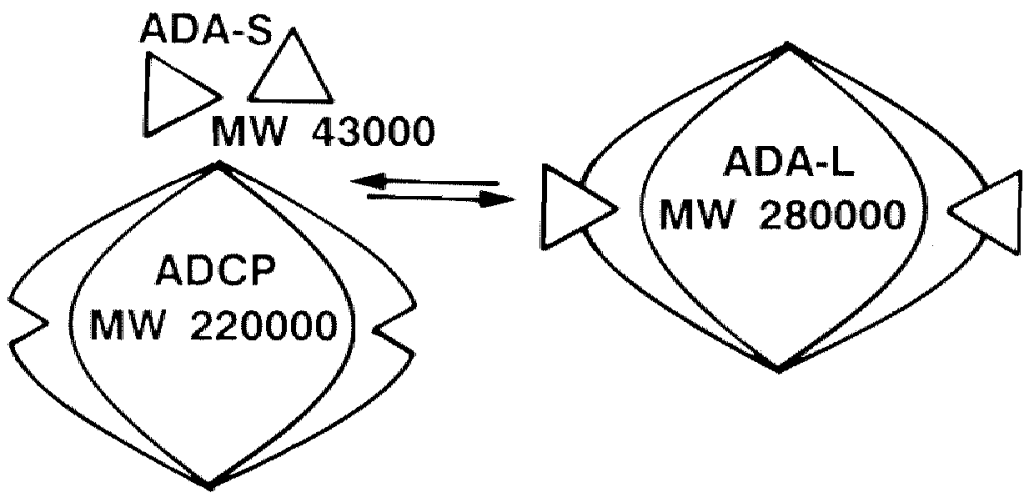

Fig. 1. Relationship between the ADA isozymes; $M W=$ molecular weight.

* Based on: Adenosine deaminase complexing protein in cancer studies, Ten Kate J, Dinjens WNM, Meera Khan P., Bosman FT.

Anticancer Res. 6: 983-988, 1986. 


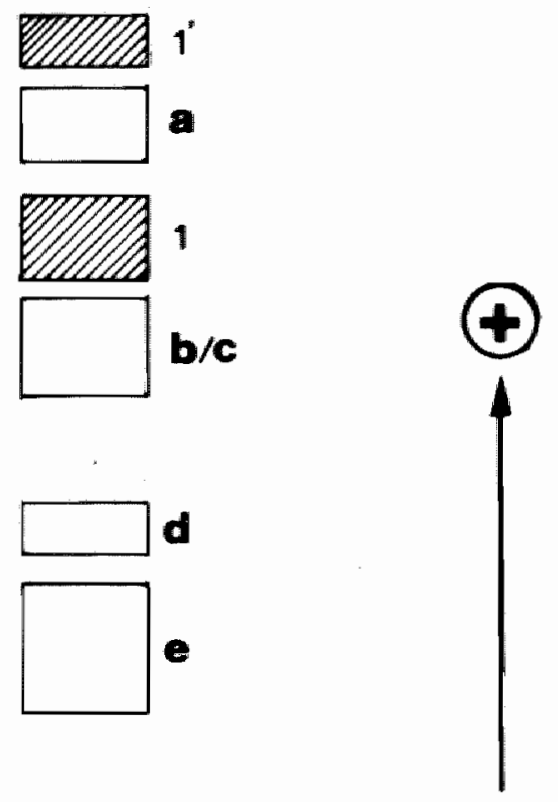

\section{Origin}

Fig. 2. Schematic representation of ADA isozymes observed in various human tissues seen in starch gel after electrophoresis at $\mathrm{pH}$ 6.5.1, I" and 1" are bands of ADA-S, phenotype 1; ADA-L, a, b, c, d indicate different isozymes of ADA-L. ADA-e: an approximately 440,000 D molecular weight form (from ref. 14).

(see ref. 4 for a review). The ADA-L occurs in four different isozymes which are separable by electrophoresis in starch gels. They have been designated as ADA a, $b, c$, and $d$, in decreasing order of electrophoretic mobility $(11,13,14)$. The isozymes $a, b$, and $c$ are glycosylation derivatives of $d(5,14)$. ADA $e$, another isozyme of about $440 \mathrm{kD}$ occurs exclusively in the intestine (5) and contains ADA-S as well as ADCP antigenic sites (14). In an electric field ADA e migrates cathodal in contrast to ADA d (Fig. 2) (5, 13, 14).

ADCP was initially detected as a soluble protein $(1,3,15)$ but subsequently shown to occur in high quantities in plasma membranes $(6,7,14,16-18)$. It occurs in membrane bound and cytoplasmic form in most human tissues. Andy and Kornfeld (19) proposed that soluble ADCP results from proteolysis of the membrane bound form. Highest concentrations of ADCP are found in the human prostate and kidney (14). ADCP expression has been found to be markedly decreased or completely absent in virus transformed skin fibroblasts and in certain human cancer derived cell lines $(15,20-22)$. Early studies indicated a striking decrease up to total deficiency of ADCP in primary carcinomas of lung, colorectum, liver and kidney $(3,23)$. 
However, our work on colorectal adenocarcinomas failed to confirm a consistent ADCP deficiency in cancer tissues $(15,24,25)$. Subsequent studies have demonstrated considerable intercellular heterogeneity in the expression of ADCP (17) and suggested this might be related to direction and level of cellular differentiation. This chapter briefly reviews the current knowledge on certain relevant aspects. The physicochemical characteristics of human ADCP were extensively reviewed elsewhere $(4,14)$.

\subsection{Possible physiological role of ADCP}

ADCP has been found in frog (26), chicken (27) and all investigated mammalian species $(8,9,12,28-37)$ except rodents $(38,39)$. The physiological function of ADCP is still obscure. It has been suggested that its capacity to bind ADA-S might represent its biological function. The enzyme ADA, which converts adenosine and deoxyadenosine into inosine and deoxyinosine respectively, plays an important role in the development of the immune system. Since deficiency of the enzyme is consistently associated with severe combined immunodeficiency disease $(1,14,40)$ it has been assumed that ADA activity is necessary for T-lymphocytic differentiation in man. It was suggested that complexed ADA-L is more thermostable than free ADA$S$ (41). Trotta and Balis (42) proposed that ADA-L could be a storage form of the enzyme and suggested that its presence might reflect a differentiated cell state.

Andy and Kornfeld (16) demonstrated in fibroblasts that membrane bound ADCP can bind ADA-S. More recently, Houghton et al. (43) described specific binding of ADA-S to cultured melanocytes, which contain membrane associated ADCP. In vivo studies in the rabbit by Schrader et al. (44) showed that intraveneously injected ADA-S is cleared from the blood by binding to the proximal convoluted tubules in the kidney. These studies provide indirect circumstantial evidence in favor of binding of $A D A-S$ to membrane associated $A D C P$. It was suggested by some investigators that membrane bound ADA protects cells from the toxic effects of extracellular adenosine and deoxyadenosine by extracellular metabolization $(6,44,45)$. Others have proposed that membrane bound $\mathrm{ADCP}$ might serve as a receptor for the recovery or removal of free ADA-S $(7,44)$. The need for removal of ADA-S from the circulation is not self-evident since normal human plasma contains relatively abundant quantities of ADCP and the traces circulating ADA always occur in the complexed form ADA-L $(10,14,46)$.

Alternatively, the association between $\mathrm{ADCP}$ and $\mathrm{ADA}-\mathrm{S}$ has been regarded as artificial after it was demonstrated that in plasma and various tissues the quantities of ADA-S and ADCP were not positively correlated $(16,46,47)$. Moreover, in neurons in the rabbit brain it was demonstrated by immunohistochemistry that ADA-S and ADCP do not co-localize (48). The occurrence of ADCP in human plasma, saliva, tears, urine $(10,46,49)$, semen (own unpublished observation) and in exocrine glands of the rabbit led to the suggestion that ADCP is a secretory protein (18). 


\subsection{ADCP expression and in vitro cell transformation}

Inwood et al. (20) investigated by starch gel electrophoresis the isozyme patterns of ADA in the soluble fraction of primary human fibroblasts. Cells harvested at confluency were shown to contain the ADA-L isozyme, whereas SV 40 transformed human fibroblasts were completely devold of ADA-L and only contained ADA-S. These results indicate that the expression of ADCP is impaired in virus transformed fibroblasts.

Herbschleb-Voogt et al. (15) quantified ADCP by electrophoretic analysis and radioimmunoassay in primary skin fibroblasts, in vitro transformed cell lines and tumor derived cell lines. They observed that ADCP is present in large quantities in fibroblasts but absent or nearly absent in transformed fibroblasts or tumor derived cell lines. More recently, ten Kate (14) found decreased membrane bound ADCP in these cells.

The consistent impairment of ADCP expression in all the in vitro virus transformed human cell lines led to speculations about the underlying mechanisms. Table I (from ref. 14) lists seweral possible mechanisms proposed to explain the decrease of ADCP. Cell hybridization experiments (2) suggest that B (Table I) could be the most plausible explanation, but this result was obtained from only one hybrid cell clone. Defective incorporation of ADCP in the plasma membrane (Table I, C.3) can be ruled out, since the expression of soluble as well as membrane bound ADCP was decreased. Alterations in cellular glycoproteins after transformation are extensively discussed by Hynes (50), and may be caused by one or more of the following mechanisms: reduced synthesis, reduced binding and increased rates of degradation. Decreased glycosylation may influence the quantity of a given protein as was demonstrated by Olden et al. (51) who reported that glycosylation may protect against proteolytic degradation. Finally, it is conceivable that ADCP is shed into tissue culture medium by cultured cells.

Table I Possible mechanisms for an apparent decrease of ADCP in cellular transformation

A. Somatic mutation in the structural gene of $\mathrm{ADCP}$, leading to

1. the production of an unstable protein

2. the formation of a protein which is not recognized by the ani-ADCP antiserum and can not bind ADA-S

B. Somatic mutation in a hypothetical regulatory gene

C. Alteration in glycosylation or other mechanisms of epigenetic origin

1. rendering the protein in $\mathrm{A} .2$

2. giving rise to proteolytic degradation

3. affecting the incorporation of ADCP in the plasma membrane

4. leading to hyper-secretion or a leak of ADCP into the medium 


\subsection{Is there a regulatory mechanism involved in the expression of ADCP ?}

The ADCP encoding gene was assigned to human chromosome 2 in rodent-human somatic cell hybrids $(2,52,53)$. The claim that chromosome 6 is also involved in the symthesis of ADCP, as reported by Koch and Shows (54) did not get further support $(2,52)$. Somatic cell hybrids derived from fusions between normal human ribroblasts and rodent cells (E36, a3 or RAG) express human ADCP, only when the human chromosome 2 material carrying the $A D C P$ gene is retained. If the rodent parent happens to be a mouse $\mathbf{L}$-cell derivative A9 or B82 the ADCP is not expressed (52). It is well documented that the human HeLa cell line and its derivatives do not express ADCP $(2,23)$. One of the hybrids between HeLa and mouse C1DA, L cells was found to express human ADCP (2). These observations, however scanty, indicate that a reversible regulatory phenomenon might be responsible for the apparent decrease in the level of expression of ADCP. Knowledge on the regulation of ADCP expression might shed some light on the mechanisms behind heterogeneous ADCP expression in cancer tissues reported by ten Kate et al. (17).

\subsection{ADCP in cancer studies}

Nishihara et al. (3) found no ADCP in extracts of carcinoma tissue of human lung and liver, organs which normally contain considerable amounts of ADCP. In 1978 Trotta and Balis (23) detected a profoundly decreased ADCP expression in carcinomas of kidney and colon as compared to the expression in normal kidney and colon. These authors suggested that decreased ADCP expression might be associated with cancer. Their findings could not be confirmed by more recent studies $(17,24,25$, $55,56)$. Although quantitative differences in ADCP expression were obserwed between tumor tissues and their respective adjacent normal mucosae a uniform decrease or deficiency of ADCP in colorectal adenocarcinomas was not found. The investigated carcinomas showed decreased, unaltered or increased levels of ADCP. Because the presence of ADCP in the human kidney is restricted to the epithelial cells lining the proximal convoluted tubules, it was suggested that the expression of ADCP in renal tumors might be a parameter for the classification of these neoplasms $(57,58,59)$. Recently it was claimed that cell surface expression of ADCP is associated with melanocyte transformation (43). Membrane associated ADCP reactivity was observed in epidermal melanocytes and benign junctional nevi and no reactivity was observed in premalignant dysplastic nevi and primary and metastatic melanoma lesions.

In order to investigate ADCP expression at the cellular level, normal and cancer tissues were analyzed immunohistochemically using a specific anti-human ADCP antiserum. ADCP was localized mainly in the apical regions of the luminal epithetium in the small and large intestine and in the proximal convoluted tubules of the kidney 
(17). These findings were in agreement with results of earlier studies, in which ADCP was found to be predominantly associated with apical membranes $(6,7,16$, 55). Striking intercellular heterogeneity in the intracellular distribution of ADCP in colorectal carcinomas was observed $(2,17)$. In these tumors membrane associated, granular cytoplasmic, diffuse cytoplasmic or negative staining of ADCP was observed. These staining patterns were found to occur within single tumors either alone or in combinations (17). The membrane associated and diffuse cytoplasmic staining patterns showed a high positive correlation with staining for carcinoembryonic antigen (CEA) and secretory component (SC), two tumor associated antigens (60-63). Immunoreactivity for SC was reported to be of prognostic significance (61-63). These findings led us to hypothesize that ADCP might have similar potentials as a tumor associated antigen. Furthermore, since ADCP is an apical membrane associated protein, its expression as a marker of differentiation may be used in tumor classification.

Whether or not ADCP is released from plasma membranes of epithelial cells into body fluids is not known at present. Studies on ADCP levels in sera from patients with cancer originating from tissues with high amounts of ADCP are of particular interest in this respect. High serum ADCP lavels are claimed to be found in patients with renal adenocarcinomas containing high $\mathrm{ADCP}$ levels (N.H. Bander, personal communication). Recently it was reported that the level of ADCP in urine can be used as a diagnostic marker for renal proximal tubular injury in renal transplant and cancer patients under chemotherapy $(49,64-68)$.

\subsection{Aims of the present study}

From the studies discussed in the previous paragraphs it is clear that several characteristics of ADCP suggest that it might be used as a marker in studies on cellular differentiation and tumor classification. Studies to this effect require the availability of specific antibodies, which would allow the localization of ADCP in tissue secthons by immunohistochemistry and the quantitative determination of $A D C P$ in tissue homogenates by immunoassay. With this goal the experiments described in chapter 2 were performed. They resulted in a method to generate specific polyclonal and monoclonal antibodies against minute amounts of ADCP, suitable for immunohistochemistry. In chapter 3 immunohistochemical and biochemical experiments on the ADCP expression in murine tissues are described. The suggested absence of $A D C P$ in rodents as concluded from the demonstrated lack of ADA. $L$ in these species is questioned by our results, which again led to speculations on the physiological significance of ADCP. Subsequently we established the distribution of ADCP in human tissues. These studied led to speculations on the physiological function of $A D C P$, as discussed in chapter 4. Studies concerning the possible physiological significance of the ADA binding capacity of ADCP are described in chapter 5. In these studies the presence of ADA and ADCP on human T-lymphoid cells 
was determined. Human T-lymphoid cells were used because it is generally accepted that ADA plays a crucial role in $\mathrm{T}$-lymphoid differentiation since a deficiency of ADA has been causally associated with a severe impairment in T-lymphoid differentiation. As described in chapter 6, ADCP expression is investigated in a number of normal and neoplastic epithelia including gastrointestinal, renal, endometrial, mammary and ovarian neoplasms and metastases. These neoplasms were selected in view of the high levels of ADCP expression in the corresponding normal tissues. Because high concentrations of ADCP were found in the prostate we investigated the ADCP expression patterns in 30 prostatic adenocarcinoma biopsies and compared these patterns with the presence of metastases as outlined in chapter 7. Studies on the exw pression pattern of ADCP in normal and neoplastic intestinal epithelia led to the suggestion that the presence of ADCP might be a marker for the columnar (absorptive) enterocytic cell lineage and that the pattern of expression of ADCP might be indicative for the degree of differentiation of these cells. In order to further investigate the value of ADCP expression for assessment of the level of differentiation, these patterns were studied in 4 human colorectal carcinoma derived cell lines, as described in chapter 8 . The cells were cultured using various differentiation modulating conditions and they were also grown as xenografts in athymic nude rats. The expression patterns of ADCP were compared with those of villin and sucraseisomaltase, two markers of columnar (absorptive) enterocytic differentiation. Finally, in chapter 9, the results of the preceding chapters are discussed. Especially the physiological function of ADCP and the possible value of ADCP as a parameter for classification and assessment of the biological behavior of neoplasms is reviewed.

\subsection{References}

1. Herbschleb-Voogt E, Pearson PL, Vossen JM, Meera Khan P (1981) Basic defect in the expression of adenosine deaminase in ADA SCID disease investigated through the cells of an obligate heterozygote. Hum. Genet. 56:379-3866.

2. Van Cong $N$, Weil D, Gross MS, Foubert G, Jami J, Frezal J (198I) Contrôte genétique el épigeném tique de l'expression de l'adenosine deaminase. Analyse des cellu les humaines et hybrides hommerongeur. Ann. Genel. (Paris) 24:141-147.

3. Nishihara $H$, Ishikawa $S$, Shinkai $K$, Akedo $H$ (1973) Multiple forms of human adenosine deaminase. 11 . Isolation and propertics of a conversion factor from human lung. Biochim. Biophys. Acla 302: 429-442.

4. Daddona PE, Kelley WN (1980) Anallysis of normal and mutant forms of human adenosine deaminase. A review. Mol. Cell Biol. 29: 91-101.

5. Swallow DM, Evans L, Hopkinson DA (1977) Several of the adenosine deaminase isozymes are glycoproteins. Nature 269:261-262.

6. Trotta PP (1982) \dentification of a membrane adenosine deaminase binding protein from human placenta. Biochemistry 21: 4014-4023. 
7. Schrader WP, Bryer PJ (1982) Characterization of an insoluble adenosine deaminase complexing protein from human kidney. Arch. Biochem. Biophys. 215: 107-115.

8. Trota PP, Peterfretnd RA, schonberg R, Balis E (1979) Rabbit adenosine dearninase conversion proteins. Purfication and characterization. Biochemistry 18: 2953-2959.

9. Schrader WP, Harder CM, Schrader DK (1983) Adenosine deaminase complexing proteins from the rabbit. Comp. Biochem. Physiol. 75B: 119-126.

10. Schrader WP, Stacy AR (1979) Immunoassay of the adenosine deaminase complexing proteins of human wissues and body fluids. J. Biol. Chem. 254: 11958-11963.

11. Daddona PE, Kelley WN (1978) Humath adenosine deaminase binding protein. Assay, purification and properties. J. Biol. Chem. 253: 4617-4623.

12. Weisman MI, Caiolfa VR, Parola A.H (1988) Adenosine deaminase complexing protein from bovine kidney. Isolation of two distinet subunits. J. Biol. Chem. 263: 5266-5270.

13. Edwards YH, Hopkinson DA, Harris H (1971) Adenosine deaminase isozymes in human tissues. Ann. Hum. Genet. 35: 207-219.

14. Ten Kate J. Adenosine deaminase complexing protein as a marker in cancer studies. Academic thesis, University of Leiden, 1985.

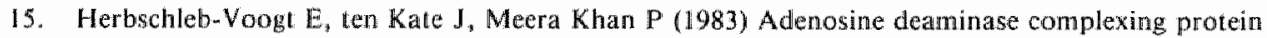
(ADCP): A transformation sensitive protein with potentials of a cancer marker. Anticancer Res. 3: $95-100$.

16. Andy R.J, Kornfeld R (1982) The adlenosine deaminase binding protein of human skin fibroblasts is located on the cell surface. J. Biol. Chem. 257: 7922-7925.

17. Ten Kate J, Wijnen JT, Boldewijn J, Meera Khan P, Bosman FT (1985) Ifmmunohistochemical localization of adenosine deaminase complexing protein (ADCP) in intestinal mueosa and in colorectall adenocarcinoma as a marker for tumour cell heterogeneity. Histochem. J. 17: 23-31.

18. Scllyader WP, West CA (1985) Adenosine deaminase complexing proteins are localized in exocrine glands of the rabbit. $J$. Histochem. Cytochem. 33: 508-514.

19. Andy RJ, Kornfeld R (1984) Biosynthesis of the adenosine deaminase-binding protein in human fibroblasts and hepatoma cells. J. Biol. Chem. 259: 9823-9839.

20. Inwood M, Povey S, Delhanty JDA (1980) Comparison of isozymes in fetal, adult and transformed fibroblasts. Cell Biol. Int. Rep. 4: 327-335.

21. Rutzky LP, Siciliano MJ (1982) Various isozyme gene expression patterns among human collorectal carcinoma cell lines and tisstes. J. Natl. Cancer Inst. 68: 81-90.

22. Wright WC, Danicls WP. Fogh J (1981) Distinction of seventy-one cultured human tumor cell lines by polymorphic enzyme analysis. J. Natl. Cane. Inst 66: 239-247.

23. Trota $\mathrm{PP}$, Balis ME (1978) Characterization of adenosine deaminase from normal colon and colon. tumors. Evidence for tumor specific variants. Biochemistry 17: 270-278.

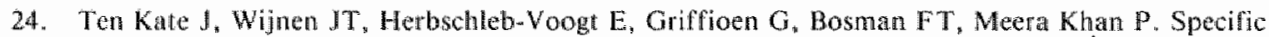
isozyme profilles of adenosine deanninase in colorectal adenocarcinoma. In: Selected topics in clinical enzymology (Goldberg D and Werner M, Eds.), Walter de Gruyter, New York, 1983, pp. 11-27.

25. Ten Kate J, Wijnen JT, van der Goes RGM, Quadt R, Griffioen $G$, Bosman FT, Meera Khan P (1984) Quantitative changes in adenosine deaminase isazymes in human colorectal adenocarcinomas. Cancer Res. 44: 4688-4692.

26. Ma PF, Fisher JR (1968) Multiple adenosine deaminases in the frog. Conp. Biochem. Physiol. 27: 105-112.

27. Mat PF. Fisher IR (1968) Two different hepatic adenosine deaminases in chicken. Biochim. Biophys. Acla 159: 153-1.59. 
28. Lee PC, Fisher JR, Ma PF (1971) Comparative and immunochemical studies of bovine adenosine deaminases. Comp. Biochem. Physiol. 40B: 1071-1077.

29. Cory JG, Weinbaum $\mathrm{G}$, Suhadolnik $\mathbb{R H}$ (1967) Multiple forms of calf serum adenosine denminase. Arch. Biochem. Bioplyys. 118: $428-433$.

30. Brady $\mathrm{TG}, \mathrm{O}^{\prime}$ Donovan $\mathrm{CI}$ (1965) A study of the tissue distribution of adenosine deaminase in six mammal species. Comp. Biochem.Physiol. 14: 101-120.

31. Ma PF, Fisher JR (1969) Comparative studies of mammalian adenosine deaminases -- some distinctive properties in higher mammals. Comp. Biochem. Physiol. 31: 771-781.

32. Ressler $N$ (1969) Tissue characteristic forms of adenosine deaminase. Clin. Chim. Acta 24:247-250.

33. Akedo J, Nishihara H, Shinkai K, Komatsu K (1970) Adenosine deaminase of two different molecular sizes in human tissues. Biochim. Biophys. Acta 212: 189-191.

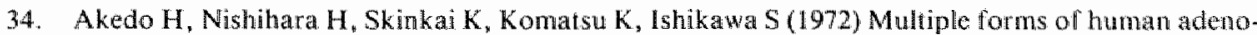
sine deaminase. 1. Purification and characterization of two molecular species. Biochim. Biophys. Acta 276: 257-271.

35. Ma PF, Magers. TA (1975) Comparative studies of human adenosine deaminase. Ini. J. Biochem. 6: $281-286$.

36. Van der Weyden MB, Kelley WN (1976) Human adenosine deaminase: Distribution and properties. J. Biol. Chem. 251: 5448-5456.

37. Hirschhorn R, Ratech $H$ (1980) Isozymes of adenosine deaminase. In: Isozymes: Current topics in biological and medical research 4: 131-157.

38. Trotta PP, Balis ME (1977) Structural and kinetic alteration in adenosine deaminase associated with the differentiation of rat intestinal cells. Cancer Res. 37: 2297-2305.

39. Trotta PP, Ahland MP, Brown GF, Balis ME (1978) Studies on the effects of infusion of enzyme inhibitors on mouse adenosine deaminase. Mol. Pharmacol. 14: 199-209.

40. Giblet ER, Anderson JE, Cohen F, Pollara B, Meuwissen HJ (1972) Adenosine deaminase deficiency in two patients with severely impaired cellular immunity. Lancet ii: 1067-1069.

41. Hirschhorn R, Beratis N, Rosen FS (1976) Characterization of residual enzyme activity in ribroblasts from patients with adenosine deaminase deficiency and combined immunodeficiency: Evidence for a mutant enzyme. Proc. Natl. Acad. Sci. USA 73: 213-217.

42. Trotta PP, Balis ME (1977) Enzyme wariants in normal and neoplastic intestinal mucosa. Cancer 40: 2592-2599.

43. Houghton AN, Albino AP, Cordon-Cardo C, Davis LJ, Eisinger M (1988) Cell surface antigens of human melanocytes and melanoma. II. Exp. Med. 167: 197-212.

44. Schrader WP, Harder CM, Schrader DK, West CA (1984) Metabolism of several molecular forms of adenosine deaminase intraveneously infused into the rabbit. Arch. Biochem. Biophys. 230: $158-167$.

45. Chechik BE, Baumal $\mathbb{R}$, Sengupta $S$ (1983) Localization and identily of adenosine deaminase postive cells in tissues of young rat and calf. Histochem. $\mathbb{1}$. 15: 373.387.

46. Schrader WP, Woodward FJ, Pollara B (1979) Purification of an adenosine deaminase complexing protein from human plasma. J. Biol. Chern. 254: 11964-11968.

47. Schrader WP, Pollara B (1978) Localization of an adenosine deaminase binding protein in luman kidney, J. Lab. Clin. Med. 92: 656-662.

48. Schrader WP, West CA, Strominger NL (1987) Localization of adenosine deaminase and addenosine deaminase complexing protein in rabbit brain. J. Histochem. Cytochem. 35: 443-451. 
49. Thompson RE, Hewitt CR, Piper DJ, Hansen WP, Rubin RH, Tolkofl-Rubir WE, Barret MC, Nelles MJ (1985) Competitive idtotype-anti-idioype inmunoassay for adenosine deaminase binding protein in urine. Clin. Chem. 31: 1833-1837.

50. Hynes RO (1976) Cell surface proteins and maligmant transformation. Biochim. Biophys. Acta 458: $73-107$.

51. Ohden $K$, Bernard BA, White SL, Parent JB (1982) Function of the carbohvdrate moieties in glycoptoteins. J. Cell Biochem. 18: $313-335$.

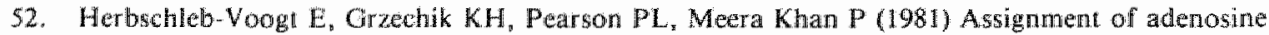
deaminase complexing protein $(A D C P)$ gene(s) to human chromosome 2 in roden - human somatic cell hybrids. Hum. Genet. 59: $317-323$.

53. Koch $\mathrm{O}$, Shows $\mathrm{TB}$ (1980) Somatic cell genetics of adenosine deaminase expression and severe combined imminodeficiency discase in humans. Proc. Nat. Acad. Sci. USA 77: 4211-4215.

54. Konth G, Shows. TB (1978) A gene on human chromosone 6 functions in assembly of tissue specific adenosine deaminase isozymes. Proc. Natl. Acad. Sci. USA 75: 3876-3880.

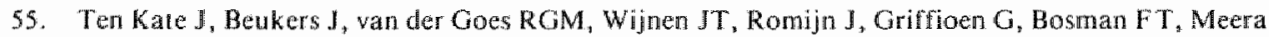
Khan P. Adenosine deaminase complexing protein (ADCP): A transformatilon sensitive marker and a possible tool in inmumodiagnostics of solid tumors. In: Proc. 1 colloquium Protides Biol. Fiuids (Peelers H, Ed.), Pergamon Press, Oxford, 1984, pp. 355-358.

56. Ten Kate 3 , van den Ingh HFGM, Meera Khan P, Bosman F T (1986) Adenosine deaminase complexing protein (ADCP) immunoreactivity in colorectal carcinoma. Inc. J. Cancer 37: 479-485.

57. Ueda R, Ogata SI, Morrissey DM, Finstad CL, Szkudlarek J, Whitmore WF, Oettgen HF, Lloyd $\mathrm{KO}$, Old L. $\mathrm{J}$ (1981) Cell surface anigens of human renal cancer defined by nouse monoctlonal anti. bodies: Identification of tissue-specific kidney glycoprotens. Proc. Natl. Acad. Sci. USA 78: $5122-5126$.

58. Andy RJ, Finstad CL, Old LJ, Lloyd KO, Kornfeld R (1984) The amigen identified by a mouse monoclonal antbody raised against human renal cancer cells is the adenosine deaminase binding protein. J. Biol. Chem. 259: $12844 \times 12849$.

59. Finstad CL, Cordon-Cardo C, Bander NH, Whitmote WF, Melamed MR, Old LJ (1985) Specificity analysis of mouse monoclonal antibodies defining cell surface antigens of human renal cancer. Proc. Natl. Acad. Sci. USA 82: 2955-2959.

60. Rogers GT (1983) Carcinoembryonic antigens and related glycoproteins, molecular aspects and specifictty. Biochen. Biophys. Acta 695: 227-249.

61. Arends JW, Wiggers T, Thijs CT, Versijnen C, Swaen GIV, Bosman FT (1984) The walue of secretory component (SC) ummunoratetivity in diagnosis and prognosis of colorectal carcinomas. Ann. J. Clin. Pathol, 82:267-274.

62. Rognum TO, Brandizaeg P, Orjasaeter H, Eigjo K. Hognestad J (1980) Immunohistochemical study of sectetory component, secretory $\lg$ A and carcinoembryonic antigen in large bowel carcinow mias. Pathol. Res. Pract. 170; 126-145.

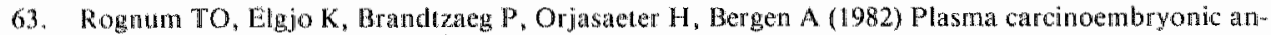
ligen concentrations and imminohistochemical patterns of epilhelial marker antigens in patients with large bowel carcinoma. 1. Clin. Pathol. 5: 922-933.

64. Thompson RE, Piper DJ, Gaberg C, Chan TH, Tolkoff Rubin NE, Rubin RH (1985) Adenosine deaminase binding protein, a new diagnostic marker for kidney disease. Clin. Chem. 31: 679-683.

65. Tolkofr-Rubin NE, Cosimi AB, Demonico FL, Russell PS, Thompson RE, Piper DJ, Hansen WP. Bander N/, Finstad CL, Cordon-Cardo C, Klow LH, Old LI, Rubia RH (1986) Monitorimg of renal proximal ubular injury in transplantation with a monoclonal antibody based assay for the add nosine deaminase binding protein. Transpl. Proc. XVIII: 716-718. 
66. Tolkoff-Rubin NE, Cosimi AB, Delmonico FL, Russell PS, Thompson RE, Piper DJ, Hansen WP. Bander NH, Finstad CL, Cordon-Cardo C, Klotz LH, Old LJ, Rubin RH (1986) Diagnosis of ubular injury in renal transplant patients by a urinary assay for pirokimal tubular antigen, the adenosine-deaminase-binding protein. Transplantation 41: $593-597$,

67. Goren MP, Wright RK, Horowitz ME (1986) Increased levels of urinary adenosine deaninase binding protein in children treated with cisplatin or methotrexate. Clin. Chim. Acta 160: 157-161.

68. Goren MP, Wright RK, Horowitz ME, Prat CB (1986) Cancer chemotherapy-induced vibular nephrotoxicity evaluated by immunochemical determination of urinary adenosine deaminase binding protein. Am. J. Clin. Pathol. 86: 780-783. 



\section{Chapter 2}

\section{Solid phase adsorption of antigens for efficient production of antibodies reactive with native and fixed tissue antigens*}

\subsection{Introduction}

The production of antibodies for use in routine immunocytochemistry is often complicated by limited availability of the antigen of interest, poor immunogenicity of the antigen, or lack of reactivity of the antibodies with the target antigens after routine tissue fixation and embedding. The limited availability and poor immunogenicity of the antigen can be alleviated by the use of immunostimulating adjuvants (1, 2 ), chemical coupling of the antigen with a potent immunogenic carrier (3-8), intrasplenic immunization $(6,8,9)$ or adsorption of the antigen to a solid phase $(8)$. Lack of immunoreactivity of an antibody with the antigen in a tissue bound form can be alleviated by immunization with appropriately processed antigen in combination with selection of antibodies for reactivity with the antigen as it is present in processed tissues. An important disadvantage of the usual hybridoma supernatant screening by enzyme linked immunosorbent assay (ELISA) is that antibodies detected with this technique do not necessarily react with the antigen in different physical or chemical conditions (e.g. in solution (10) or in fixed and processed tissue (11)). To circumvent this problem hybridoma supernatant screening should be performed with the technique in which the obtained antibody will be eventually used.

We have attempted to generate polyclonal and monoclonal antibodies against adenosine deaminase complexing protein (ADCP), a homodimeric glycoprotein of $220 \mathrm{kD}(12)$, which would allow detection of this protein in routinely processed normal and neoplastic human tissues by immunohistochemistry. In the present paper we describe a procedure for the generation of monoclonal and polyclonal antibodies against nanogram quantities of purified native or denatured ADCP, which detect the antigen in sections of formalin fixed and paraffin embedded human kidney, prostate and small intestine.

\footnotetext{
* Dinjens WNM, van der Linden EPM, Signet CM, Wijnen JT, Meera khan P, wen Kate J, Bosman FT. Submitted for publication.
} 


\subsection{Materials and Methods}

\subsubsection{Antigen purification and processing}

ADCP was purified from human renal cortex as described previously by ten Kate et al. (13). For immunization 20 ng of ADCP dissolved in $20 \mu$ phosphate buffered saline (PBS) were applied onto nitrocellulose membrane (Schleicher and Schuell, Dassel, FRG). Alternatively, polyvinylidene difluoride (PVDF, Immobilon, Millipore, Bedford MA, USA) membranes were used as solid phase. Prior to application of the antigen, triangular membrane pieces were prewetted in methanol and washed in PBS. ADCP was applied to the wet membrane $(2 \mu \mathrm{g}$ in $10 \mu \mathrm{l}$ PBS). This was subsequently fixed in formalin, embedded in paraffin by routine methods, dewaxed and rebydrated, exposed to methanol with $0.5 \%(\mathrm{v} / \mathrm{v})$ hydrogen peroxide (as is customary prior to immunostaining of tissue sections) and washed in PBS. After this processing ADCP was still present on the membrane as determined with a protein specific dye (Aurodye forte, Janssen, Olen, Belgium). The processed antigen bearing membrane fragments (app. $5 \mathrm{~mm}^{2}$ ) were implanted either subcutaneously (s.c.) or intrasplenically (i.s.) in female Balb/c mice. Intrasplenic implantations were performed as described by Nilsson et al. (8). Briefly, the spleen is carefully exposed and with the edge of a needle a small slit is made in the splenic capsule through which the membrane is inserted into the spleen. Hemostasis is accelerated by covering the spleen with a small piece of thrombin impregnated paper (Spongostan, Ferrosan, Denmark).

\subsubsection{Immunization protocols}

The various immunization protocols are outlined in Table I. Nine mice were immunized each 5 times at monthly intervals by 20 ng of native ADCP in PBS per immunization. The antigen was administered intraveneously (i.v.) (A), intraperitoneally (i.p.) (B) or s.c. (C) without adjuvant (A) or with $50 \%$ (v/v) Freund's complete adjuvant (FCA, Difco, Detroit MI, USA) in the first immunization and with $50 \%(\mathrm{v} / \mathrm{v})$ Freund"s incomplete adjuvsnt (FIA) in the 4 subsequent immunizations (B and C). Seven mice were immunized s.c. 5 times with $20 \mathrm{ng}$ of native ADCP bound to a nitrocellulose membrane ( $D$ and $E$ ). Six of these mice were boosted 4 days prior to fusion s.c. ( 2 mice), i.p. ( 2 mice) or s.c. and i.p. (1 mouse) with 20 ng native ADCP bound to a nitrocellulose membrane or i.v. (1 mouse) with $20 \mathrm{ng}$ ADCP in PBS (D). One mouse was boosted $i$.p. with a lysate of human kidney cortex $(200 \mu \mathrm{g}$ protein per boost), 7, 4, 3, 2 and 1 day before fusion (E).

In protocol F 3 mice were immunized with $2 \mu \mathrm{g}$ Immobilon adsorbed and processed ADCP, twice s.c. and twice i.s. ( 2 mice) or twice i.s. (1 mouse). Of these 3, one mouse was boosted i.p. with a lysate of paraffin embedded and subsequently rehydrated human renal cortex $(200 \mu \mathrm{g}$ protein per boost), $7,4,3,2$ and 1 day prior to fusion. 


\begin{tabular}{|c|c|c|c|c|c|c|}
\hline \multirow{2}{*}{ Protocol } & \multirow{2}{*}{$\begin{array}{l}\text { No. of } \\
\text { mice }\end{array}$} & \multicolumn{4}{|c|}{ Immunizations } & \multirow{2}{*}{$\begin{array}{l}\text { Prefusion } \\
\text { boosting }^{3}\end{array}$} \\
\hline & & $\mathrm{No}^{2}$ & Site & $\begin{array}{l}\text { Antigen } \\
\text { amount }\end{array}$ & $\begin{array}{l}\text { Antigen } \\
\text { condition }\end{array}$ & \\
\hline A & 4 & 5 & i.v. & $20 \mathrm{ng}$ & native/liquid & - \\
\hline B & 3 & 5 & i.p. & $20 \mathrm{ng}$ & $\begin{array}{l}\text { native/liquid } \\
500 \% \text { FCA/FIA }\end{array}$ & - \\
\hline C & 2 & 5 & s.c. & $20 \mathrm{ng}$ & $\begin{array}{l}\text { native/liquid } \\
50 \% \text { FCA/FIA }\end{array}$ & - \\
\hline $\mathrm{D}$ & 6 & 5 & s.c & $20 \mathrm{ng}$ & $\begin{array}{l}\text { native/nitro- } \\
\text { cellulose bound }\end{array}$ & $\begin{array}{l}1 \times 20 \mathrm{ng} \text {; } \\
\text { liquid i.v.; nitro- } \\
\text { cellulose bound } \\
\text { s.c. or i.p. }\end{array}$ \\
\hline $\mathrm{E}$ & 1 & 5 & s.c. & $20 \mathrm{ng}$ & $\begin{array}{l}\text { native/nitro- } \\
\text { cellulose bound }\end{array}$ & $\begin{array}{l}5 \times 200 \mu \mathrm{g} \\
\text { native kidney } \\
\text { cortex lysate i.p. }\end{array}$ \\
\hline$F$ & 3 & $4(2)^{4}$ & $\begin{array}{l}\text { s.c. } \\
\text { and/ } \\
\text { on i.s. }\end{array}$ & $2 \mu \mathrm{g}$ & $\begin{array}{l}\text { processed/ } \\
\text { lmmobilon } \\
\text { bound }\end{array}$ & $\begin{array}{l}5 \times 200 \mu \mathrm{g} \\
\text { processed kidney } \\
\text { cortex lysate i.p. }\end{array}$ \\
\hline
\end{tabular}

1 Female Balb/c mice, 6-8 weeks of age at first immunization

2 Intervals monthly

3 Boosting performed one month after the last immunization

4 2 mice were immunized twice s.c. and twice i.s.

1 mouse was immunized twice i.s.

Of all mice serum was collected 7 days after the second and the last immunization and at fusion.

\subsubsection{Monoclonal antibody production}

Splenic leucocytes were fused with SP $2 / 0$ myeloma cells in a ratio of $2: 1$ with polyethylene glycol (PEG 1500) and the fusate was seeded in 360 wells of microtiter plates in hypoxanthine, aminopterin, thymidine (HAT) supplemented medium. $\mathrm{Balb} / \mathrm{c}$ mouse peritoneal macrophages were added as feeder cells.

Prefusion sera and the hybridoma culture supernatants were tested for anti-ADCP antibodies by indirect immunoperoxidase methods on $4 \mu \mathrm{m}$ cryostat sections, which had been fixed in periodate-lysine-paraformaldehyde (PLP) fixative (14), and on 4 $\mu \mathrm{m}$ sections of formalin or PLP fixed and routine paraffin embedded human kidney 
cortex, prostate and small intestine. The sera and supernatants were also applied on sections of processed tissues, which were preincubated with $0.1 \%(\mathrm{w} / \mathrm{v})$ trypsin (Difco, Detroit MI, USA), $0.1 \%(\mathrm{w} / \mathrm{v}) \mathrm{CaCl}_{2}$ in water, $\mathrm{pH} 7.8$ for 30 min at RT. An indirect immunoperoxidase technique was used as described by ten Kate et al. (15). As conjugate we used rabbit anti-mouse $\lg (\mathrm{H}+\mathrm{L})$ immunoglobulins labeled with horse-radish peroxidase (Dakopatts, Glostrup, Denmark). The specificity for ADCP of the immunoreactivity was determined by comparison of the reactivity pattern with that obtained with a well documented specific rabbit anti-human ADCP antiserum (13) applied on sections of PLP fixed and paraffin embedded human kidney cortex, prostate and small intestine. The large scale screening of the hybridoma supernatants was performed by immunohistochemistry on sections of human kidney cortex, prostate and small intestine. The three different tissues were embedded close to each other two times in one paraffin block. Five sections were mounted on one microscope slide in such a way that consecutive sets of tissue were at multichannel micropipet outlet distance. Before applying 10 supernatants, the slide was divided in 10 segments, each containing one set of tissues, by circling with a solid piece of paraffin to prevent admixture of the supernatants.

Antibody specificity was further evaluated by starch gel (16) and sodium dodecyl sulphate polyacrylamide gel electrophoresis (SDS-PAGE) after immunoprecipitation (17). For starch gel evaluation the antibodies were added to purified human ADCP and to a lysate of human kidney cortex. After incubation the antibodies were precipitated with Protein A coated Sepharose CL-4B (Pharmacia, Uppsala, Sweden). Bovine ADA-S (Sigma, St. Louis MO, USA) was added to the supernatants and these mixtures were subjected to starch gel electrophoresis with subsequent in situ staining for ADA activity as described previously (18).

For SDS-PAGE evaluation normal human skin fibroblasts in cell culture were metabolically labeled with ${ }^{35} \mathrm{~S}$-methionine (Amersham, UK), after which the cells were lysed. This lysate was used for the immunoprecipitation with Protein A coated Sepharose. The precipitated labeled proteins were separated by SDS-PAGE (19) blotted to a nitrocellulose membrane (20) and visualized by autoradiography.

\subsection{Results}

The results of the various immunization protocols are summarized in Table II Immunization procedures $\mathrm{A}, \mathrm{B}$ and $\mathrm{C}$ did not result in specific antibody titers in the serum. In contrast, procedures $\mathrm{D}$ and $\mathrm{E}$ resulted in specific antibody titers as determined by immunohistochemistry on cryostat and PLP fixed and paraffin embedded human tissue sections. Sufficient titers (1:500) were already obtained after the second immunization which increased only slightly after 3 subsequent immunizations. The 6 mice immunized according to protocol D were used in fusion experiments and although we obtained good fusion efficiencies (hybridomas were growing in more than $80 \%$ of the wells) no specific antibody producing clones were found. After im- 


\begin{tabular}{|c|c|c|c|c|c|c|}
\hline \multirow{3}{*}{ Protocol } & \multicolumn{3}{|c|}{ Anti-ADCP specific antiserum titer } & \multirow{3}{*}{$\begin{array}{l}\text { Serum } \\
\text { reactivity on } \\
\text { processed } \\
\text { tissues }\end{array}$} & \multirow{3}{*}{$\begin{array}{l}\text { No. of } \\
\text { MoAb }\end{array}$} & \multirow{3}{*}{$\begin{array}{l}\text { MoAb } \\
\text { reactivity on } \\
\text { processed } \\
\text { tissues }\end{array}$} \\
\hline & \multicolumn{2}{|c|}{ Immunization } & \multirow{2}{*}{$\begin{array}{l}\text { Prefusion } \\
\text { serum }\end{array}$} & & & \\
\hline & Second & Last & & & & \\
\hline A & 0 & 0 & - & no & - & - \\
\hline $\mathrm{B}$ & 0 & 0 & somer & no & - & - \\
\hline $\mathrm{C}$ & 0 & 0 & - & no & - & - \\
\hline $\mathrm{D}$ & $1: 500$ & $\mathbb{1}: 1000$ & $1: 1000$ & no & 0 & - \\
\hline $\mathrm{E}$ & $1: 500$ & $1: 1000$ & $1: 3000$ & no & 4 & no \\
\hline $\mathrm{F}$ & $\begin{array}{l}1: 200 \\
(1: 500)^{2}\end{array}$ & $1: 500$ & $1: 1500$ & $y_{e s}{ }^{3}$ & 1 & yes $^{3}$ \\
\hline
\end{tabular}

MoAb = monoclonal antibody

2 Mouse immunized twice î.s.

${ }^{3}$ Reactivity after trypsin pretreatment of tissue sections

munization according to protocol $\mathrm{E}$ increased prefusion serum antibody titers were found $(1: 3000)$ but with considerable non-ADCP related immunoreactivity (Fig. 1A). When immunostaining by rabbit anti-mouse IgM (Fig. 1B) peroxidase and rabbit anti-mouse IgG peroxidase conjugates (Fig. 1C) were compared, ADCP specific staining was clearly detectable by anti-IgG conjugates only. Fusion after protocol $E$ resulted in 4 different ADCP reactive monoclonal antibodies (1071, 1072, 1079 and 1080). Specificity was proven by demonstrating the disappearance of $A D C P$ in a purified ADCP containing solution and in a human kidney lysate after immunoprecipitation. This was performed by starch gel electrophoresis of the supernatants followed by specific in situ staining for ADA activity (Fig. 2).

Specificity was also determined by immunoprecipitation in a membrane extract of ${ }^{35} \mathrm{~S}$-methionine labeled human fibroblasts and SDS-PAGE of the precipitated proteins. Representative results are shown in Fig. 3. Two proteins of molecular weight $109 \mathrm{kD}$ and $43 \mathrm{kD}$ are specifically precipitated by the monoclonal antibody. None of the (polyclonal or monoclonal) antibodies generated against native ADCP reacted with this antigen in formalin fixed paraffin embedded tissues, not even after a wide variety of proteolytic, glycolytic or lipolytic treatments. After immunization with ADCP adsorbed to Immobilon membrane and processed according to rout ine tissue processing protocols, however, immune sera were obtained which reacted with $A D C P$ in routinely formalin fixed and paraffin embedded tissues but only after trypsin treatment. After processing, ADCP no longer reacted with anti-native ADCP 


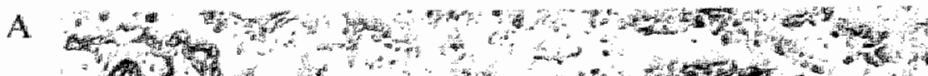
of 1
1 ro

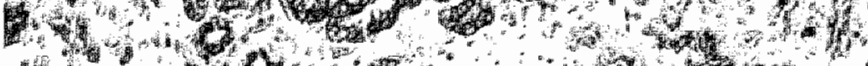

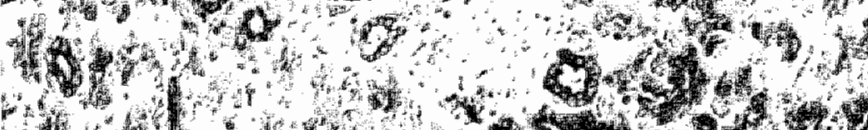

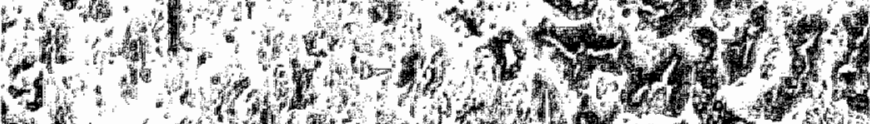
H. T.4.

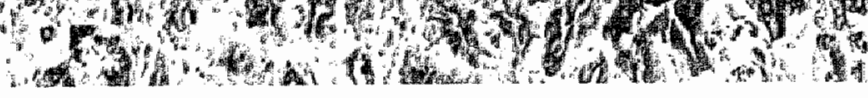

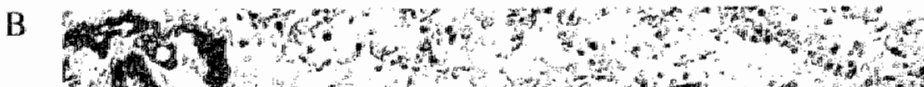

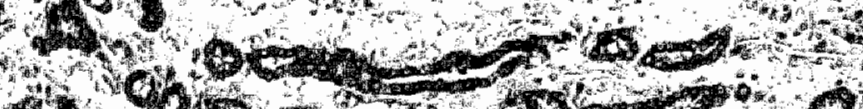

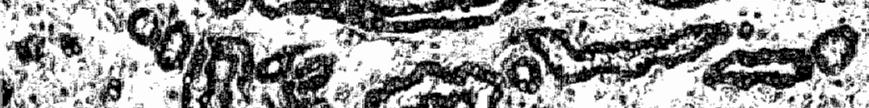

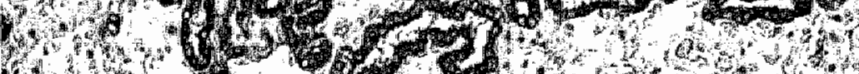

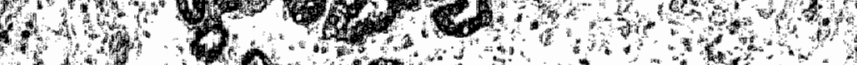

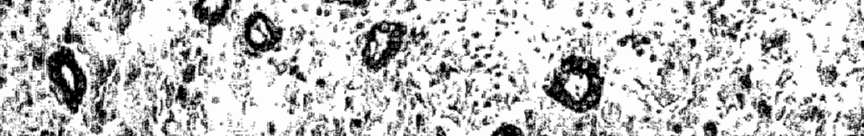
HW

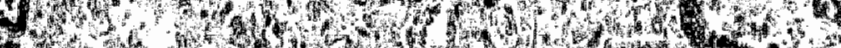

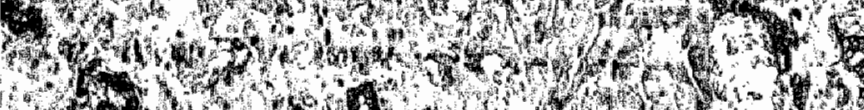

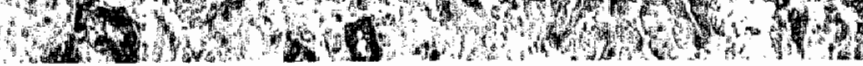

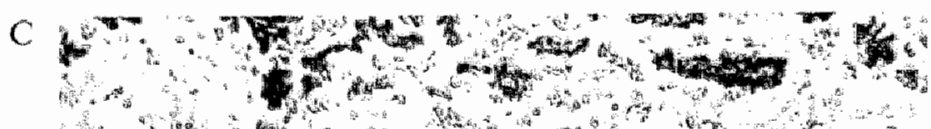

Fig. 1.

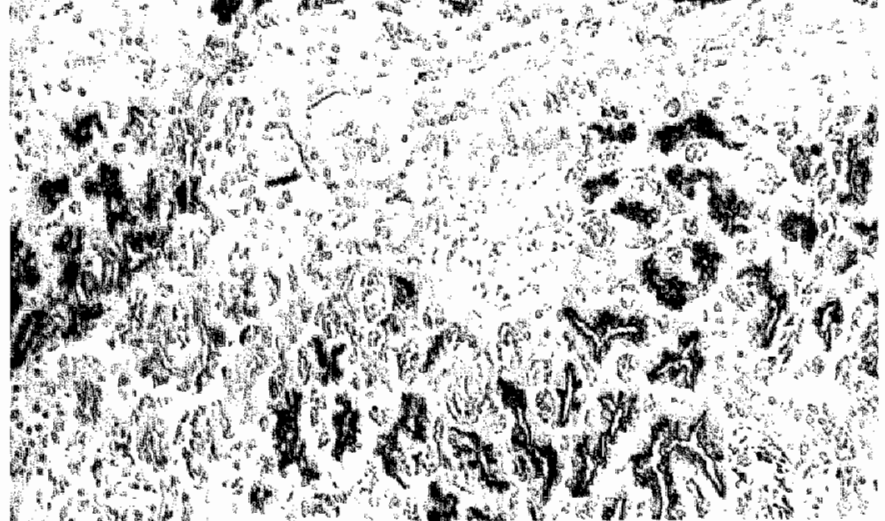


Fig. 1. Prefusion reactivity of mouse anti-ADCP antiserum (immunized according to protocol E) on 3 serial sections of a PLP fixed human kidney cortex.

A. Reactivity detected with rabbit anti-mouse total $\mathrm{lg}$. Immunoreactivity is observed in the cytoplasm of the proximal and distal tubular epithelial cells. The proximal tubular epithelial cells also show weak apical membrane associated reactivity (immunoperoxidase, $120 \times)$.

B. Reactivity of the same serum detected with rabbit anti-mouse IgM. Immunoreactivity is observed in the cytoplasm of the distal and proximal tubular epithelial cells. The proximal tubular epithelial cells do not show apical membrane associated reactivity (immunoperoxidase, $120 \times$ ).

C. Reactivity of the same serum detected with rabbit anti-mouse $1 \mathrm{gG}$. Strong apical membrane associated immunoreactivity is observed in the proximal tubular epithelial cells. The distal tubules are negative (immunoperoxidase, $120 \times$ ).

antibody but reactivity was obtained with antibodies generated against processed ADCP (not shown). Fusion of spleen cells of an immune mouse resulted in a monoclonal anti-ADCP antibody after boosting with a lysate of processed human renal cortex. Using this procedure (Table I, F) one monoclonal antibody was obtained which reacted with paraffin embedded kidney, prostate and small intestine but only after trypsin treatment. However, reactivity appeared to be restricted to those, high ADCP containing, tissues.

\subsection{Discussion}

The described procedures allow the generation of polyclonal and monoclonal antibodies against ng amounts of purified antigen (ADCP) reactive with native and fixed tissue antigens. Our results demonstrate that administration of ng quantities of ADCP adsorbed to a solid phase is highly effective for the generation of polyclonal antisera, whereas administration of the same amount of ADCP in solution is not sufficient to obtain specific antibodies in the serum. This can be due to an immunostimulating effect of the nitrocellulose membrane. Other possibilitios are that imnobilized ADCP has undergone conformational changes, increasing its immunogenicity, or that immobilized ADCP is less susceptible to proteolysis leading to a persistent local high concentration of ADCP as was suggested by others (7). Combinations of these possibilites can not be ruled out. This procedure theoretically has the advantage that small quantities of antigens are more likely to induce anti. bodies with high affinity for the antigen.

Our failure to generate monoclonal antibodies after immunizing mice according to procedure $\mathrm{D}$ is in line with the findings of Stähli et al. (21). These investigators demonstrated that repeated immunization with $\mu \mathrm{g}$ quantities of antigen is adequate to obtain high serum antibody titers but is insufficient to generate monoclonal antibodies. They as well as others (6) suggested that this is due to a lack of sufficient numbers of antigen specific blast cells in the spleen. In our experiments this pro- 


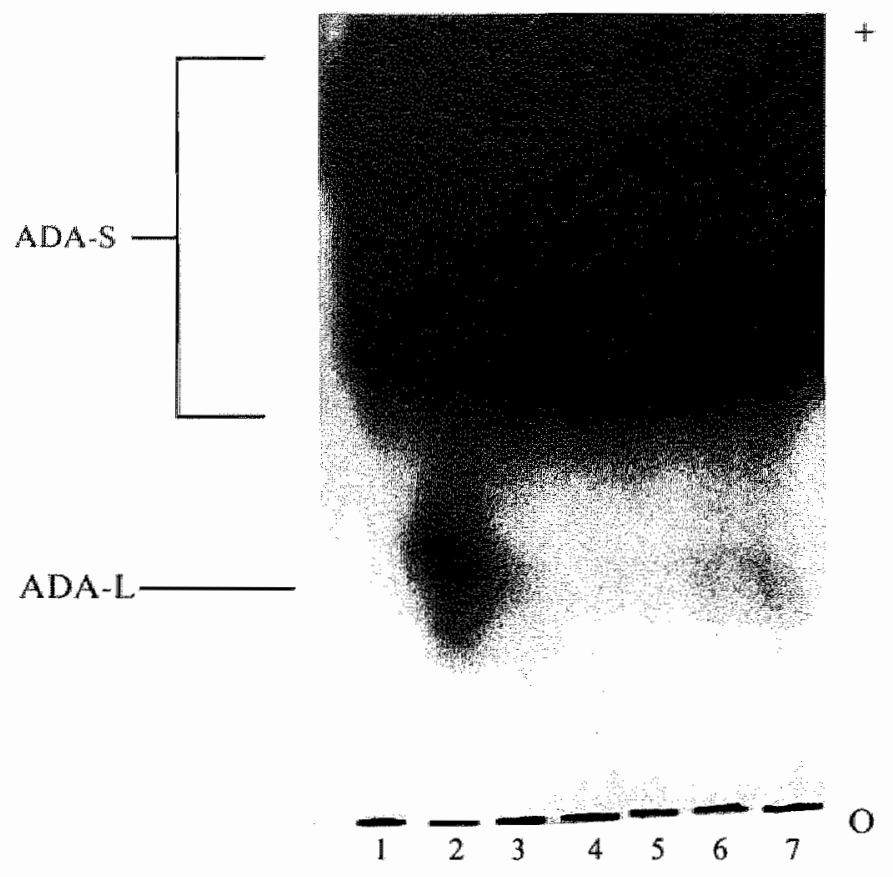

Fig. 2. Starch gel patterns of ADA isozymes in the supernatant, after immunoprecipitation with monoclonal antibody 1071 , of a lysate of human kidney cortex. $O=$ origin.

Lane 1 calf ADA-S.

Lane 2 human kidney lysate + calf ADA-S.

Lane 3 immunoprecipitation with monoclonal antibody (ascites) 1:100. Before electrophoresis of the supernatant calf ADA-S is added.

Lane 4 as 3 but antibody dilution 1:200

Lane 5 as 3 but antibody dilution 1:500

Lane 6 as 3 but antibody dilution 1:1000

Lane 7 as 3 but antibody dilution 1:2000

Note the gradual appearance of ADA-L (ADCP) in the supernatant with increasing antibody dilution.

posed small number of antigen specific blast cells in the spleen can be explained by the subcutaneous administration of solid phase adsorbed antigen because the spleen is known to respond primarily to blood-borne antigens. Successful production of monoclonal antibodies was achieved after repeated boosting of the mice (5 times in 7 days prior to fusion) with high amounts $(200-400 \mu \mathrm{g})$ of purified antigen. Our results demonstrate that $i . v$. boosting prior to fusion can be effectively performed with impure antigen preparations. By boosting with an ADCP containing lysate the specific antibody titer in the serum increases together with generation of a nonADCP specific antibody titer. With the rabbit anti-mouse $\operatorname{IgG}$ and $\operatorname{IgM}$ peroxidase conjugates it is possible to discriminate between ADCP specific and non specific reactivity. 'This result is in agreement with the generally accepted concept that with the applied boosting procedure (procedure $\mathrm{E}$ ) the presence of $\mathrm{ADCP}$ in the lysate 


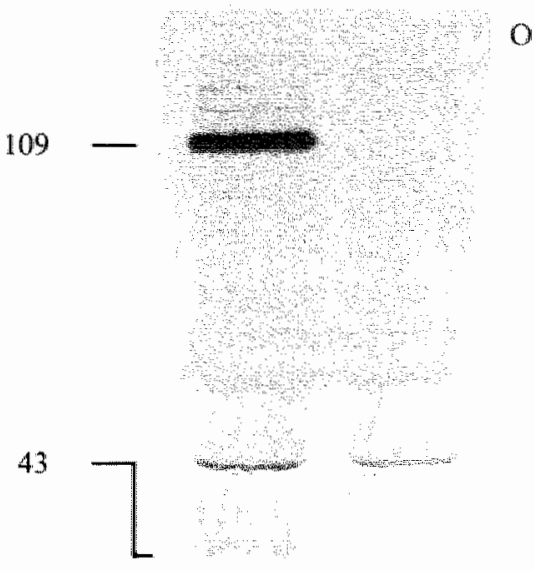

12

Fig. 3. Autoradiogram of immunoprecipitates after SDS-PAGE. Lysate of metabolically labeled human fibroblasts was immunoprecipitated with monoclonal antibody 1071 (ascites) (lane 1) and control ascites (lane 2). Two specific proteins of 109 and $43 \mathrm{kD}$ respectively are precipitated. $\mathrm{O}=$ origin.

generates a secondary antibody response of the IgG type, whereas the other immunogenic components in the lysate are responsible for a primary humoral response of the IgM type. The finding that with procedure $\mathbb{E}$ the antibody titer in the serum is increased and the observation that only this procedure results in the generation of specific monoclonal antibodies suggests that by boosting with impure antigen preparations it is possible to increase the proportion of antigen specific blast cells in the spleen to a level at which a successful fusion can be performed.

For the generation of polycional and monoclonal antibodies which detect ADCP in sections of routinely processed tissues we also used immobilized antigen. The method is based on the tight binding of the antigen to a solid phase (Immobilon membrane) and the subsequent processing of the coated membrane. The Immobilon membrane is very suited for this procedure because of its high binding capacity for proteins $(22,23)$ and its resistance against organic solvents. The validity of this procedure is indicated by the finding that the sera of all 3 mice immunized with processed ADCP (procedure F) reacted with sections of processed human kidney cortex, prostate and small intestine, whereas none of the rabbit and mouse polyclonal and monoclonal antibodies against native ADCP reacted with these sections, 
even after extensive attempts to restore the immunoreactivity (11, 24-26).

We also found that rabbit antiserum against native human $A D C P$ does not react: with immobilized processed $\mathrm{ADCP}$ and the polyclonal and monoclonal antibodies against processed ADCP show no reactivity on cryostat sections. Obviously, formaIin fixation and paraffin embedding of native $A D C P$ results in the modification of native antigen epitopes. It has been reported that formalin fixation causes irreversible alteration of proteins mainly due to inter- and intra protein methylene bridge formation (27). These formalin induced alterations are thought to be responsible for the inability to detect antigens in processed tissues with antibodies directed against the native antigen. With regard to $A D C P$, however, the combination of formalin fixation and paraffin embedding appears to affect the immunoreactivity. On cryostat sections post-fixed in formalin or embedded in paraffin ADCP specific immunoreactivity was observed with the rabbit antiserum against native human ADCP. However, on cryostat sections passed through both procedures the immunoreactivity was destroyed. We suggest that the necessity of trypsin digestion for restoration of immunoreactivity is due to masking of the epitopes on the ADCP molecule in the sections of processed tissues. This masking is probably caused by fixation and embedding incluced interaction of ADCP with other tissue components because the antibodies did react with immobilized and processed purified ADCP. The reactivity of the monoclonal antibody, generated against processed ADCP, was found to be restricted to kidney, prostate and small intestine. This probably points to a concentration dependent reactivity because these tissues are known to contain high amounts of $\mathrm{ADCP}$.

In summary, solid phase adsorption can be a versatile and efficient approach for immunization with ng quantities of antigen. Processing of the adsorbed antigen according to the routine tissue fixation and embedding protocol can result in antibodies which detect the antigen in sections of routinely processed lissues. The combination of primary immunization with solid phase adsorbed pure antigen and boosting with impure antigen is a useful approach for the generation of monoclonal antibodies against minute amounts of pure antigen.

\subsection{References}

1. Galfre G. Milstein C (1981) Preparation of monoclonal antibodies: Strategies and procedures. Methods Enzymol. 73: 3-46.

2. Atassi MZ (1986) Preparation of monoclonal antibodies to preselected protein regions. Methods Enzymol. 121: 69-95.

3. Mäkcli O. Seppälä IJT. Haptens and carriers. In: Handbook of experimental immunology, vol. 1: Immunochemistry, 4th ed., (DM Weir, Ed.), Blackwell Scientific Publ., Oxford, 1986, pp. 3.1-3.13. 
4. Kearney JF, Radbruch A, Liesegang B, Rajewsky K (1979) A new monse myeloma cell line that has lost immunoglobulin expression but permits the construction of antibodysecreting hybrid cell lines. J. Immunol. 1.23: 1548-1550.

5. Eager KB, Kennet. RH. (1986) The use of conventional antisera in the production of spectic monoclonal antibodies. Methods Enzymol. 121: 59-69.

6. Spitz M (1986) "Single-shot" intrasplenic immunization for the production of monoclonal antibodies. Methods Enzymol. 121: 33-41.

7. Bellstedt DU, Human PA, Rowland GF, van der Merwe KJ (1987) Acidtreated, naked bacteria as immune carriers for protein antigens. J. Immunol. Methods 98: 249-255.

8. Nilsson BO, Svalander PC, Larsson A (1987) Immunization of mice and rabbits by intrasplenic deposition of nanogram quantities of protein attached to Sepharose beads or nitrocellulose paper strips. J. Immunol. Methods 99: 67-75.

9. Spitz M, Spitz L, Thorpe R, Eugui E (1984) Intrasplenic primary immunization for the production of monoclonal antibodies. J. limmunol. Methods $70 ; 3943$.

10. Vaidya HC, Dietzler DN, Ladenson JH (1985) Inadequacy of traditional ELISA for screening hybridoma supernatants for murine monoclonal antibodies. Hybridoma 4: 271-276.

11. Havenith MG, Cleutjens JPM, Beek C, van der Linden E, De Goeij AFPM, Bosman FT (1987) Human specific anti-type IV collagen monoclonal antibodies, characterization and immunohistochemical application. Histochemistry 87: 123-128.

12. Daddona PE, Kelley WN (1980) Analysis of normal and mutant forms of human adenosine deaminase. A review. Mol. Cell Biol. 29:91.101.

13. Ten Kate J, Wijnen JT, van der Goes RGM. Quadt R, Griffioen G, Bosman $\mathbb{I}^{2} T$, Meera Khan P (1984) Quantitative changes in adenosine deaminase isozymes in human colorectal adenocarcinomas. Cancer Res. 44: 4688-4692.

14. McLean IW, Nakane PK (1974) Periodate-lysine-paraformaldehyde fixative. A new fixative for immunoelectronmicroscopy. J. Histochem. Cytochem. 22: 1077.

15. Ten Kate J, Wijnen JT, Boldewijn J, Meera Khan P, Bosman FT (1985) Immunohistochemical localization of adenosine deaminase complexing protein (ADCP) in intestinal mucosa and in colorectal adenocarcinoma as a marker for tumour cell heterogeneity. Histochem. J. 17: 23-31.

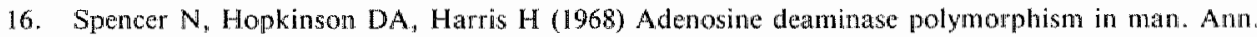
Human Genet. 32: 9-14.

17. Andy RJ, Kornfeld R (1984) Biosynthesis of the adenosine deaminase-binding protein in hunatr fibroblasts and hepatoma cells. J. Biol. Chem, 259: 9823-9839.

18. Herbschleb-Voogt E, Grzechik KH, Pearson PL, Meera Khan P (1981) Assignment of adenosine deaminase complexing protein (ADCP) gene(s) to human chromosome 2 in rodent-human somatic cell hybrids. Hum. Genet. 59: 317-323.

19. Laemmli UK (1970) Cleavage of structural proteins during the assembly of the head of the bacteriophage T4. Nature 227: 680-685.

20. Towbin H, Staehelin T, Gordon J (1979) Electrophoretic transfer of proteins from polyacrylamide gels to nitrocellulose sheets: Procedure and some applications. Proc. Natl. Acad. Sci. USA 76: $4350-4354$.

21. Stähli C, Stachelin T, Miggiano $V$, Schmidt J, Häring P (1980) High frequencies of antigen-specific hybridomas: Dependence on immunization parameters and prediction by spleen cell analysis. If. Im. munol. Methods 32: 297-304.

22. Blankenstein LA, Dohrman L. An advanced affinity membrane for immunodiagnostic tests. Am. Clin. Prod. Rev. november 1985. 
wskal MG, Przekop MB, Kavonian MR, Vecoli C. Hicks DA (1986) Immobilon TM PWDF trans$r$ membrane: A new membrane substrate for western bloting of proteins. Biotechnigues $4:$ 2283 .

wran RC, Gregory I (1978) Demonstration of immunoglobulin in cryostat and paraffin secions human consil by immunofluorescene and immunoperoxidase techniques. Ef ects of processing 1 immunohistochemical performance of tissues and on the use of proteolytic enzymes to unmask itigens in sections. J. Clin. Pathol. 31: 974-983.

atutzer NW, Witkulhn JF, McCaughey WTE (1980) Trypsin digestion in immunoperoxidase staing. J. Histochem. Cytochem. 28:52.53.

arsky SH, Rao NC, Restrepo C, Liotta LA (1984) Immunocytochemical enhancenent of baseent membrane antigens by pepsin: Applications in diagnostic pathology. Am. J. Clin. Pathol. 82: 11.194.

whtler H, Meloan SN (1985) On the chemistry of formaldehyde fixation and its effects on imunohistochemical reactions. Histochemistry 82: 201-204. 


\section{Chapter 3}

\section{Distribution of adenosine deaminase complexing protein (ADCP) in murine tissues*}

\subsection{Introduction}

Adenosine deaminase $(\mathrm{ADA}, \mathrm{EC}$ no. 3.5.4.4), the enzyme which catalyses the ir. reversible hydrolysis of adenosine and deoxyadenosine to inosine and deoxyinosine, occurs in 2 major molecular weight forms in a number of vertebrate species including frog, chicken, cattle, rabbit and man (1-4). These 2 ADA forms are designated as ADA-S and ADA-L. ADA-S is a monomer with a molecular weight of $43 \mathrm{kD}$. ADA-L, with a molecular weight of about $280 \mathrm{kD}$, is composed of 2 molecules of ADA-S bound to a homodimeric complexing protein (ADA-complexing protein, ADCP) (5). By complexing with ADCP ADA-S can be converted to ADA-L (5). Initially described as a soluble protein, ADCP was subsequently shown by immunohistochemistry and by quantitative biochenical studies to belocalized predominantly in plasma membranes (4,6-12). The physiological need for ADCP is still obscure. As yet, its capacity to bind $\mathrm{ADA}-\mathrm{S}$ has been the only recognized property of $\mathrm{ADCP}$. The importance of the ADCP binding, however, is not fully established because ADA-S and ADA-L have identical catalytic and regulatory properties (13), although it was claimed that ADA-L is more thermostable than free ADA-S (14). Trotta and Balis (15) postulated that ADA-L could be a storage form of the enzyme and its presence was thought to be characteristic for a differentiated cell state. In a number of studies evidence has been obtained that membrane bound $\mathrm{ADCP}$ can bind $\mathrm{ADA}$ $S(10,16,17)$ and it was suggested that membrane bound ADA might protect cells from the toxic effects of adenosine and deoxyadenosine by extracellular metabolization $(8,18)$. Schrader and Bryer (9) and Schrader et al. (19) proposed that membrane associated ADA-free ADCP might serve as a receptor for the recovery or removal of the free ADA-S from the circulation. Other studies have suggested that there are no functional relationships between ADA and ADCP and that their association in tissue homogenates is an artifact because in some tissues the quantities of ADA-S and ADCP did not show any correlation $(10,19,20)$. Furthermore, Schrader et al. (21) clearly demonstrated immunohistochemically that ADA-S and ADCP are not co-localized in the rabbit brain. In biochemical experiments rat and mouse tissues

* Dinjens WNM, ten Kate J, Wijnen JT, Signet CM, Beek C, wan der Linden EPM, Mecra Khan P. Bosman FT. Submitted for publication. 
did not exhibit any ADA-L, which led to the suggestion that rodents lack ADCP $(22,23)$. In the present paper we report the presence of ADCP immunoreactivity in the mouse and rat, using an anti-human $A D C P$ antiserum which detects $A D C P$ in man, rabbit and cattle (24). The investigated characteristics, in particular the tissue and subcellular distribution, and the electrophoretic mobility in starch and polyacrylamide gels of the protein in the mouse and rat, correspond with those of ADCP with the exception that the protein does not bind ADA-S. Also this finding might argue against the significance of $\mathrm{ADCP}$ for the ADA function.

\subsection{Materials and Methods}

\subsubsection{Immunohistochemistry}

Human, mouse (Balb/c) and rat (Wistar) tissues were obtained at autopsy and immediately frozen in isopentane at $-80^{\circ} \mathrm{C}$ or fixed in periodate-lysine-paraformaldehyde (PLP) (25). Subsequently the PLP fixed tissues were routinely paraffin embedded. For the immunohistochemical detection of ADCP we used $4 \mu \mathrm{m}$ paraffin or cryostat sections. The cryostat sections were fixed in PLP for $10 \mathrm{~min}$ at room temperature (RT). After deparaffinization and rehydration of the paraffin sections or fixation of cryostat sections, they were washed in phosphate buffered saline (PBS). Endogenous peroxidase activity was inhibited by treating the sections with a $0.5 \%(\mathrm{v} / \mathrm{v})$ solution of hydrogen peroxide in methanol $(30 \mathrm{~min}, \mathrm{RT})$. To prevent non-specific binding the sections were incubated with $20 \%(\mathrm{v} / \mathrm{v})$ normal goat serum (10 min, RT). Thereafter the anti-ADCP antiserum and goat anti-rabbit Ig peroxiclase conjugate (Nordic, Tilburg, The Netherlands) were applied 2 and 1 hour respectively at $\mathrm{RT}$. Between each incubation, sections were rinsed $(3 \times 5 \mathrm{~min})$ with PBS. All antiserum dilutions were prepared with PBS containing 1\% $(\mathrm{w} / \mathrm{v})$ bovine serum albumin (BSA, RIA grade, Sigma, St. Louis MO, USA). Peroxidase activity was visualized with $0.01 \%(\mathrm{v} / \mathrm{v})$ hydrogen peroxide and $0.05 \%(\mathrm{w} / \mathrm{v})$ diaminobenzidine tetrahydrochloride (DAB, Serva, Heidelberg, $\mathrm{FRG}$ ) in Tris- $\mathrm{HCl}$ buffer $(\mathrm{pH}$ 7.6) and the sections were counterstained with hematoxylin.

\subsubsection{Starch gel electrophoresis}

Mouse kidney cortex samples were cut into small pieces and washed with cold $0.9 \%$ $\mathrm{NaCl}$ solution. Homogenization was performed as a $50 \%$ suspension in $250 \mathrm{mM}$ sucrose, $20 \mathrm{mM}$ imidazole hydrochloride $\mathrm{pH} 7.0$, with an Ystral dispenser X 10/20 (Salm and Kipp, Breukelen, The Netherlands). The $2,000 \mathrm{~g}$ ( $20 \mathrm{~min}$ ) supernatant of the homogenate was collected and centrifuged at $4^{\circ} \mathrm{C}$ for $45 \mathrm{~min}$ at $18,000 \mathrm{~g}$. The pellet was treated with a buffer consisting of $5 \mathrm{mM}$ sodium phosphate $\mathrm{pH} 6.4$ containing $1 \mathrm{mM}$ disodium EDTA and $1 \mathrm{mM}$ B-mercaptoethanol with $0.125 \%$ deoxycholic acid sodium salt and $0.25 \%$ Triton X-100, sonicated (with a Sonocone sonica- 
tor with energy level adjusted to 7 ) on ice for 10 seconds and left for 30 min at $37^{\circ} \mathrm{C}$. After centrifugation $\left(45 \mathrm{~min}, 18,000 \mathrm{~g}, 4^{\circ} \mathrm{C}\right)$ the supernatant was regarded as the membrane fraction.

Human ADCP was purified from kidney cortex as described previously (24). Starch gel electrophoresis was performed according to Spencer et al. (26) with modifications (27). After electrophoresis the whole gel was sliced horizontally into 2 parts. The upper part was stained for ADA activity. The lower part of the gel was used for electrotransfer of the separated proteins to a nitrocellulose membrane (Schleicher and Schuell, Dassel, FRG). Immunodetection of the blotted proteins was performed as follows. After electrotransfer the membrane was washed ( 3 times $10 \mathrm{~min}$ ) in PBS $+0.05 \%$ Tween 20 (PBT). Subsequently the membrane was incubated overnight (RT) with anti-ADCP antiserum (1:2000 in PBS + 1\% (w/v) BSA), washed in PBT and incubated (1h, RT) with goat anti-rabbit Ig alkaline phosphatase conjugate (Nordic, Tilburg, The Netherlands). After washing in PBT alkaline phosphatase activity was visualized with nitro blue tetrazolium chloride monohydrate (Janssen, Beerse, Belgium) and 5-bromo-4-chloro-3-indolylphosphate (Boehringer, Mannheim, FRG). The reaction was terminated by washing the membrane in $\mathrm{H}_{2} \mathrm{O}$. As a specificity control normal rabbit serum was applied on a parallel blot.

\subsubsection{Sodium dodecyl sulphate polyacrylamide gel electrophoresis (SDS-PAGE)}

Metabolic labeling, preparation of membrane extracts, immunoprecipitation and SDS-PAGE were performed according to Andy and Kornfeld (28). In short: cultures of primary mouse and human skin fibroblasts at confluency were labeled for 18 hours with $100 \mu \mathrm{Ci}{ }^{35} \mathrm{~S}$-methionine $(1213 \mathrm{Ci} / \mathrm{mmol}$; Amersham, UK). Membrane extracts were prepared and precipitated with Protein A Sepharose CL-4B ( $1 \mathrm{~h}$; Pharmacia, Uppsala, Sweden) and with normal rabbit serum (overnight) and Protein A Sepharose CL-4B (1 h). The supernatants were incubated overnight with rabbit anti-ADCP or normal rabbit serum, and precipitated for 1 hour with Protein A Sepharose. The immunoprecipitates were solubilized and subjected to SDSPAGE performed according to Laemmli (29) using $7.5 \%$ polyacrylamide slab gels. After electrophoresis the separated proteins were blotted onto a nitrocellulose membrane (30). The lane containing the molecular weight standards was cut from the membrane and the standards were visualized by specific protein staining (Aurodye forte, Janssen, Olen, Belgium). The other part of the membrane was dried and exposed to X-ray film (Kodak X-OMAT) at $-70^{\circ} \mathrm{C}$. 


\subsection{Results}

\subsubsection{Immunohistochemistry}

In mouse and rat tissues very strong immunoreactivity was found in the brush border of the epithelial cells of the proximal convoluted tubules in the renal cortex. Glomeruli, distal tubules, endothelium and erythrocytes were all negative (Fig. 1). In the prostate immunoreactivity was found in the apical membrane and apical cytoplasm of the glandular epithelial cells. Immunohistochemistry was also applied on sections of mouse and rat small and large intestine and liver (not shown). The immunoreactivity patterns in kidney, prostate, small and large intestine and liver (not shown) exactly resemble those observed in human tissues.

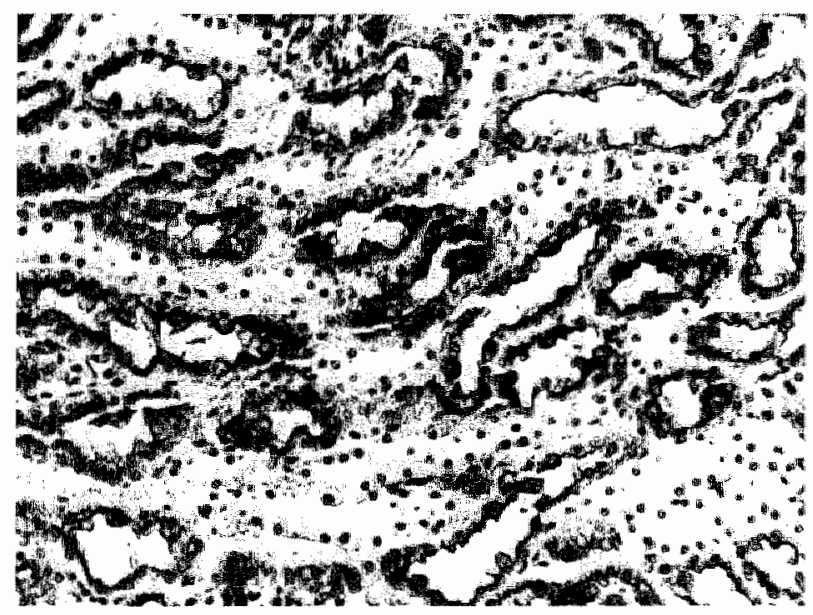

Fig. 1. Immunoreactivity of the anti-ADCP antiserum on a cryostat section of mouse kidney cortex (immunoperoxidase, $250 \times$ ). Note the strong apical mem. brane associated reactivity of the proximal tubular epithelial cells.

\subsubsection{Starch gel electrophoresis}

In Fig. 2A the result of starch gel electrophoresis and in situ staining for ADA activity of lysates of mouse kidney cortex and mouse and human erythrocytes are shown. The human hemolysate did not contain ADA-L. Mouse kidney cortex lysate did not. exhibit an ADA-L band. Addition of mouse or human hemolysate (as sources of ADA-S) or bovine ADA-S (not shown) to this lysate, did not result in the appearance of an ADA-L band. Also no ADA-L band could be visualized after addition of mouse hemolysate to purified human ADCP. Immunoblotting after starch gel electrophoresis (Fig. 2B) revealed that the mouse kidney cortex lysate contained an ADCP immunoreactive protein with electrophoretic mobility somewhat lower than human ADCP. This band was not found in the mouse hemolysate. Addition of hemolysate resulted in an additional anodal band on immunoblotting. 
A

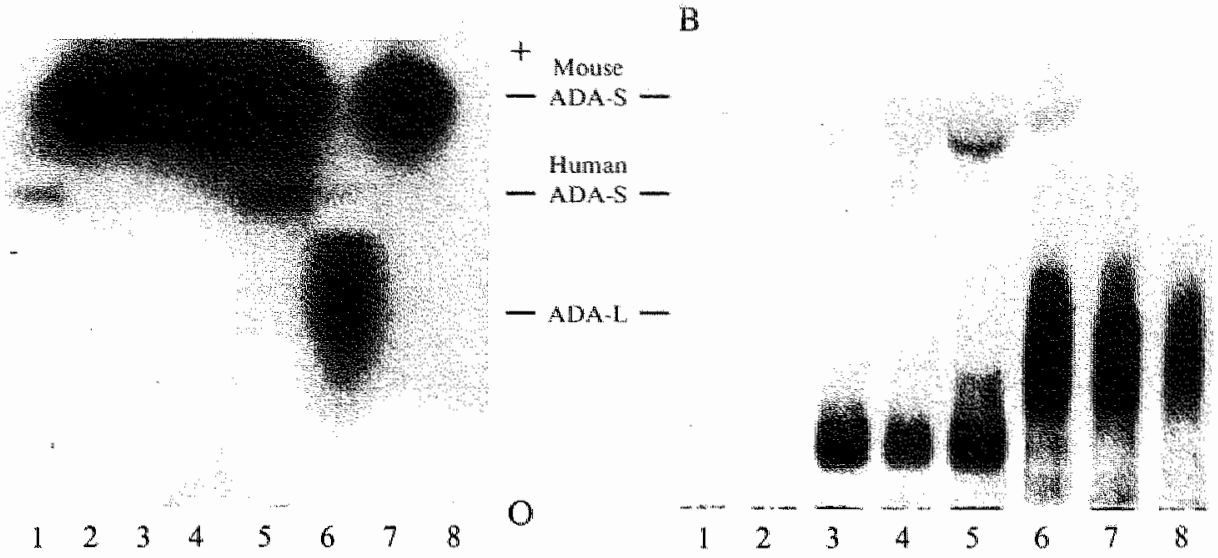

Fig. 2. Starch gel electrophoresis of purified human ADCP and of lysates of mouse kidney cortex and mouse and human erythrocytes. One gel is sliced horizontally in two parts. The upper part is stained in situ for ADA activity (A). The lower part is used for immunobloting with anti-ADCP antiserum $(B) . O=$ origin.

Lane 1 lysate of human erythrocytes

Lane 2 lysate of mouse erythrocytes

Lane 3 lysate of mouse kidney

Lane 4 mixed lysates of mouse erythrocytes and mouse kidney

Lane 5 mixed lysate of mouse kidney and human erythrocytes

Lane 6 lysate of human erythrocytes and purified human ADCP

Lane 7 lysate of mouse erythrocytes and purified human ADCP

Lane 8 purified human ADCP

Note that the lysate of mouse kidney cortex contains ADCP-reactive protein (B, lane 3,4 and 5) that does not bind mouse and human ADA-S (A, lane 3,4 and 5). Mouse ADA-S does also not bind to human ADCP (lane 7).

\subsubsection{SDS-PAGE}

To determine the molecular weight of the mouse ADCP immunoreactive protein immunoprecipitates of membrane fractions of metabolically labeled confluent mouse skin fibroblasts were analyzed by autoradiography after SDS-PACE and electroblotting. As shown in Fig. 3, the anti-ADCP antiserum specifically precipitates from mouse fibroblasts 2 proteins of about 109 and $95 \mathrm{kD}$, comparable to ADCP precipitated from confluent human fibroblasts.

\subsection{Discussion}

Trotta and Balis (22) and Trotta et al. (23) were the first to demonstrate that in mouse and rat tissues ADA-L does not occur. Considering the binding of ADA-S to ADCP as an important functional characteristic, several investigators concluded 


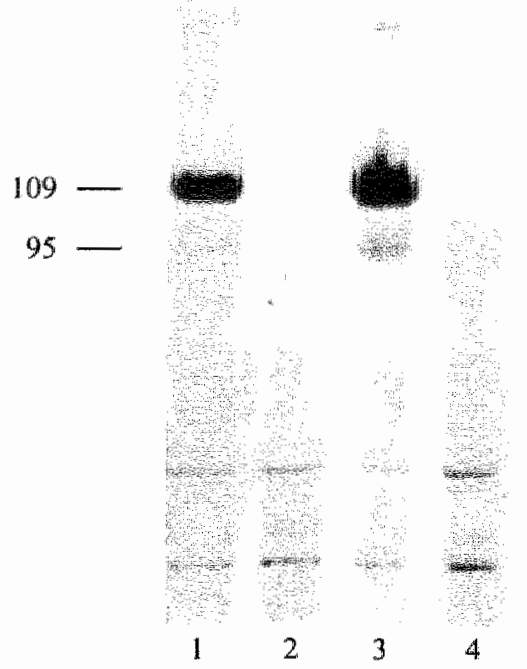

Fig. 3. Autoradiogram of immunoprecipitates after SDS-PAGE. Lysates of metabolically labeled human (lane 1 and 2) and mouse fibroblast (lane 3 and 4), were immunoprecipitated with rabbit anti-human ADCP antiserum (lane 1 and 3 ) and normal rabbit serum (lane 2 and 4). Two specific proteins of 109 and $95 \mathrm{kD}$ respectively are precipitated, $\mathrm{O}=$ origin.

that rodents do not have ADCP $(21,22,31)$. By starch gel electrophoresis and in situ staining for ADA activity we confirmed the results of Trotta and Balis $(22,23)$. However, we could detect ADCP immunoreactive material in an electroblot after starch gel electrophoresis of a mouse kidney cortex lysate with an electrophoretic mobility close to that of human ADA-L (ADCP). The applied antiserum recognizes human as well as rabbit and bovine ADCP, indicating the presence of species crossreactive epitopes in the $A D C P$ molecule. Addition of mouse or human hemolysate (as source of ADA-S) or calf ADA-S to the mouse kidney cortex lysate did not result in an ADA-L band after starch gel electrophoresis and in situ staining for ADA activity. These results suggest the presence in rodents of an ADCP like molecule which, however, does not bind ADA-S. In order to further characterize this rodlent ADCP analog membrane fractions of metabolically ( ${ }^{35} \mathrm{~S}-$-methionine) labeled mouse and human fibroblasts were immunoprecipitated with our anti-ADCP antiserum. The immunoprecipitates were analyzed by autoradiography after SDS-PAGE and electroblotting. The results unequivocally show that in the mouse 2 proteins occur which are precipitated by anti-human ADCP antiserum and have similar electrophoretic mobility (apparent molecular weights of 109 and $95 \mathrm{kD}$ ) to the human proteins. The precipitated $95 \mathrm{kD}$ protein has also been reported in the literature (24, 28 ) and has been regarded as a degradation product of the mature $110 \mathrm{kD}$ protein. These results support the existence of significant homology between human ADCP and the mouse protein that has no ADA-S binding capacity.

Further evidence to support the similarity between human $\mathrm{ADCP}$ and mouse 
ADCP-like protein is derived from immunohistochemical studies in the mouse and the rat using the anti-human $A D C P$ antiserum. These studies show that the tissue localization of the mouse and rat protein closely corresponds with that of the human ADCP.

In summary, our findings show that in rodents an ADCP immunoreactive protein occurs which corresponds with human ADCP in apparent molecular weight, electrophoretic mobility and cell and tissue localization but which lacks the capacity to bind ADA-S. These findings cast serious doubt on the importance of ADCP binding for the function of ADA. The physiological function of ADCP remains to be established.

\subsection{References}

1. Ma PF, Fisher JR (1968) Multiple adenosine deaminases in the frog. Comp. Biochem. Physiol. 27: $105-112$.

2. Ma PF, Fisher JR (1968) Two different hepatic adenosine deaminases in chicken. Biochim. Biophys. Acta 159: 153-159.

3. Cory JG, Weinbaum G, Suhadolnik RJ (1967) Multiple forms of calf serum adenosine deaminase. Arch. Biochem. Biophys. 118: 428-433.

4. Nishihara H, Ishikawa $S$, Shinkai K, Akedo $H$ (1973) Multiple forms of human adenosine deaminase. II. Isolation and properties of a conversion factor from human lung. Biochim. Biophys. Acta 302: $429-442$.

5. Daddona PE, Kelley WN (1980) Analysis of normal and mutant forms of human adenosine deaminase. A review. Mol. Cell Biol. 29: 91-101.

6. Herbschleb-Voogt E, Pearson PL, Vossen JM, Meera Khan P (1981) Basic defect in the expression of adenosine deaminase in $\mathrm{ADA}^{-}$SCID disease investigated through the cells of an obligate heterozygote. Hum. Genet. 56: 379-386.

7. Herbschleb-Voogt E, ten Kate J, Meera Khan P (1983) Adenosine deaminase complexing protein (ADCP): A transformation sensitive protein with potentials of a cancer marker. Antisancer Res. 3: $95 \cdot 100$.

8. Trotta PP, Peterfreund RA, Schonberg R, Balis ME (1979) Rabbit adenosine deaminase conversion proteins. Purification and characterization. Biochemistry 18: 2953-2959.

9. Schrader WP, Bryer PJ (1982) Characterization of an insoluble adenosine deaminase complcxing protein from human kidney. Arch. Biochem. Biophys. 215: 107.115.

10. Andy RJ, Kornfeld R (1982) The adenosine deaminase binding protein of human skin fibroblasts is located on the cell surface. J. Biol. Chem. 257: 7922-7925.

11. Ten Kate J, Wijnen JT, Boldewijn J, Meera Khan P, Bosman FT (1985) Immunohisiochumical localization of adenosine deaminase complexing protein (ADCP) in intestinal mucosa and in colorectal adenocarcinoma as a marker for tumour cell heterogeneity. Histochem. $J .17: 23-31$.

12. Sehrader WP, West CA (1985) Adenosine deaminase complexing proteins are localized in exocrine glands of the rabbit. J. Histochem. Cytochem. 33: 508-514.

13. Hirschhorn R, Ratech H (1980) Isozymes of adenosine deaminase. In: Isozymes: current topics in biological and medical research 4: 1.31-157. 
14. Howchmorn $R$, Geratis N, Rosen FS (1976) Chatacterization of residual enzyme activily in fibro. blasts from patients wh adenosine deaminase deficiency and combined immunodeficiency: evidence for a mulant enzyme. Proc. Nat. Acad. Sci. USA 73:213-217.

15. Trofta PP, Balis ME (1977) Enxyme variants in nomal and neoplastic intestinal mucosa. Cancer $40: 2592-2599$

16. Houghion AN, Abino AP, Cordor-Cardo C, Davis Ll, Eisinger M (1988) Cell surface antigens of human melanocytes and melanoma. J. Exp. Med. 167: 197-212.

17. Dinjers WNM, van der Boon J, ten Kate J, Zeillemaker WP, De Bruijn CHMM, Bosman FT, Weera Khan $P$ (1986) Cell surface adenosine deaminase (ADA) and its complexing protein (ADCP) in human "Iympthoid cells. Adv. Exp. Med. Biol. 195B: 407-414. (This thesis Chapter 5).

18. Chechik BE, Balmal R, Sengupca $S$ (1983) Localization and identity of ademosine deaminase posirive cells in tissues of young tat and call. Histocheri, J. 15:373-387.

19. Schrader WP, Woodward FJ, Pollara B (1979) Purification of an adenosine deaminase complexing protein from thuman plasma. J. Bial. Chem. 254: $11964-11968$.

20. Schrader WP, Pollara B (1978) Localization of an adenosine deaminase binding protein in thuman kidney. I. Lab. Clin. Med. 92: 656 662.

21. Schrader WP, West CA, Strominger NL (1987) Localization of adenosine deaminase and adenosine deaminase complexing protein in rabbit brain. J. Histochem. Cytochem. 35: 443-451.

22. Trotta PP. Balis ME (1977) Stuctural and kinetic alteration in adenosine deaminase associated with the differentiation of rat intestimal cells. Cancer Res. 37: 2297-2305.

23. Trotla PP, Ahland MP, Brown GF, Balis ME (1978) Studies on the effects of infusion of enzyme inhibilots on mouse adenosine deaminase. Molec. Pharmacoil. 14: 199-209.

24. Ten Kate J, Wijnen JT, van der Goes RGM, Quadt R, Grifloen G, Bosman FT, Meera Khan P (1984) Quantitative changes in adenosine deaminase isozymes in human colorectal adenocarcinomas. Cancer Res. 44: 4688-4692.

25. Mclean IW, Nakane P (1974) Periodate-1ysine-paraformaldehyde fixative, A new fixative for immunoelectronmicroscopy. J. Histochem. Cytochem. 22; 1077.

26. Spencer N, Hopkinson DA. Harris H (1968) Adenosine deaminase polymorphüm in man. Ann. Hum. Genet. 32: 9-14.

27. Herbsclnleb.Voogt E, Grzechik KH, Pearson PL, Meera Khan P (1981) Assignment of adenosine deaminase complexing protein (ADCP) gene(s) to human chromosome 2 in rodent human somaic cell hybrids. Hum. Genet. 59: 317-323.

28. Andy R.I, Konnleld R (1984) Biosynthesis of the adenosine deaminase binding protein in humarn ribroblasts and hepaloma cells. J. Biol. Chem. 259: 9823-9839.

29. Lacmmli UK (1970) Cleavage of structural proteins during the assembly of the head of the bacteriophage T4. Nature $227: 680-685$.

30. Towbin $H$, Stathelin T, Gordon J (1979) Electrophoretic transfer of proteins from polyacrylanide gels 10 nitrocellulose sheets: procedure and some applications. Proc. Natl. Acad. Sci. USA 76: $4350-4354$.

31. Kellems RE, Yeung CY, Ingolia DE (1985) Adenosine deaminase deficiency and sewere conbined intumodeficiencies. Trends Genetics 1: $278-283$. 


\section{Chapter 4}

\section{Distribution of adenosine deaminase complexing protein $(\mathrm{ADCP})$ in human tissues*}

\subsection{Introduction}

The adenosine deaminase complexing protein (ADCP) was found to occur mainly in plasma membranes (1-5). In man, $\mathrm{ADCP}$ has been demonstrated by immunohistochemistry to be predominantly localized in the brushborders of the epithelial cells of the proximal convoluted tubules in the kidney $(1,4,6)$ and of the small and large intestine (4). In addition, Finstad et al. (6) reported the immunohistochemical detection of ADCP in epithelial cells of human placenta, prostate, breast and lung without details on subcellular localization. Quantitative biochemical studies in man showed that ADCP occurs predominantly in the membrane fraction of the homogenates of kidney, lung, liver, spleen, thymus, small intestine (1), placenta (2), and skin fibroblasts (3). The occurrence of ADCP in human plasma, saliva, tears, urine (4-9), semen (Dinjens et al, unpublished observations) and in exocrine glands of the rabbit (5) led to the suggestion that $\mathrm{ADCP}$ is a secretory protein.

$A D C P$ attracted some attention in cancer research when it was reported that the protein was decreased or completely absent in cancers of human lung, liver, kidney and colorectum (10,11). However, our group failed to confirm a consistent decrease of ADCP in colorectal adenocarcinomas $(4,12-14)$. On the other hand, a profound and uniform decrease of ADCP expression was observed in a number of in vitro virus transformed human skin fibroblasts as well as in certain cancer derived cell lines $(12,15-17)$.

The aforementioned findings prompted us to investigate the normal distribution of ADCP in the human body, both quantitatively and immunohistochemically. The obtained information might shed some light on the physiological function of ADCP and provide a baseline for studies regarding ADCP expression in relation to neoplasia.

* Dinjens WNM, ten Kate, J, van der Linden EPM, Wijnen JT, Meera Khan P, Bosman FT, Subminted for publication. 


\subsection{Materials and Methods}

\subsubsection{Tissue sources and antiserum}

Normal human tissues were obtained from surgically removed specimens or from autopsies performed within 5 hours after death. Specific anti-human ADCP antiserum was raised in a Chinchilla rabbit (14). The animal was immunized with ADCP purified from normal human kidney. Specificity of the antiserum was proven by immunoprecipitation. The anti-ADCP antiserum detects free ADCP as well as ADCP complexed with ADA-S, but does not recognize ADA-S (14).

\subsubsection{Radioimmunoassay (RIA)}

The fresh tissues were cooled on ice and washed with cold $0.90 \%(\mathrm{w} / \mathrm{v}) \mathrm{NaCl}$ solution. Each tissue was cut into smaller pieces and homogenized as a $50 \%$ suspension in $250 \mathrm{mM}$ sucrose, $20 \mathrm{mM}$ imidazole hydrochloride $\mathrm{pH} 7.0$, with an Ystral Dispenser $\mathrm{X} \rrbracket 0 / 20$ (Salm and Kipp, Breukelen, The Netherlands). The $20 \mathrm{~min} 2,000 \mathrm{~g}$ supernatant of the homogenate was collected and centrifuged at $4^{\circ} \mathrm{C}$ for $45 \mathrm{~min}$ at 18,000 g. The supernatant was regarded as the soluble fraction and stored at $-80^{\circ} \mathrm{C}$. The pellet was treated with a buffer consisting of $5 \mathrm{mM}$ sodium phosphate $\mathrm{pH} 6.4$ containing $1 \mathrm{mM}$ disodium EDTA and $1 \mathrm{mM} \beta$-mercaptoethanol with $0.125 \%$ deoxycholic acid sodium salt and $0.25 \%$ Triton $X-100$, sonicated (with a Sonocone sonicator with energy level adjusted to 7) on ice for 10 seconds and left for $30 \mathrm{~min}$ at $37^{\circ} \mathrm{C}$. After centrifugation $\left(45 \mathrm{~min}, 18,000 \mathrm{~g}, 4^{\circ} \mathrm{C}\right.$ ) the supernatant was regarded as the membrane fraction, and stored at $-80^{\circ} \mathrm{C}$. The ADCP specific radioimmunoassay was essentially carried out as described by Daddona $e t$ al. (18) with modifications (14). In short, ${ }^{125} \mathrm{I}$ labeling of purified human ADCP was performed with the lactoperoxidase technique described by Chechick et al. (19) resulting in a specific activity of $\mathrm{ADCP}$ of about $11 \mathrm{Ci} / \mathrm{g}$. The sample antiserum mixture was incubated for one night at $4^{\circ} \mathrm{C}$. To each sample, $1.00 \mu \mathrm{l}$ of iodinated ADCP with $10,000 \mathrm{cpm}$ were added, incubated for 3 days at $4^{\circ} \mathrm{C}$ and immunoprecipitated with a $1 \%$ Staphylococcus aureus suspension. The standard curve was made with serial dilutions of a human kidney extract. The detection limit was found to be $11 \pm 2$ (mean \pm SD) $\mathrm{ng} / \mathrm{ml}$ with a $95 \%$ confidence limit. Samples were measured in duplicate, in 3 different dilutions, such that at least 2 dilutions fell within the range of the standard curve. Protein content was estimated by the method of Lowry et al. (20).

\subsubsection{Immunohistochemistry}

Our anti-ADCP antiserum did not detect ADCP in sections from routinely formalin fixed and paraffin embedded tissues. Therefore we used $4 \mu \mathrm{m}$ sections from periodate-lysine-paraformaldehyde (PLP) (21) fixed and routinely paraffin embedded tissues or $4 \mu \mathrm{m}$ cryostat sections which were fixed in PLP for $10 \mathrm{~min}$ at room 
temperature (RT). This PLP fixation of cryostat sections was found to be superior with respect to tissue morphology as compared with aceton fixation. From each tissue type, samples of at least 3 different individuals were examined. The procedure for the indirect immunoperoxidase technique was followed as described by ten Kate et al. (4). In short, after deparaffinization and rehydration of paraffin sections or fixation of cryostat sections they were whed in phosphate buffered saline (PBS). Endogenous peroxidase activity was inhibited by treating the sections with a $0.5 \%$ $(v / v)$ solution of hydrogen peroxide in methanol (30 min, RT). To prevent nonspecific binding the sections were incubated (10 min, RT) with $200 \%(\mathrm{v} / \mathrm{v})$ normal goat serum. Thereafter the ant-ADCP antiserum and goat anti-rabbit Ig peroxidase conjugate (Nordic, Tilburg, The Netherlands) were applied 2 and 1 hour respectively at RT. Between each incubation, sections were rinsed ( $3 \times 5 \mathrm{~min})$ with PBS. All antiserum dilutions were prepared with PBS containing $1 \%(\mathrm{w} / \mathrm{v})$ bovine serum albumin (RIA grade, Sigma, St.Louis MO, USA). Peroxidase activity was visualized with $0.01 \%(\mathrm{v} / \mathrm{v})$ hydrogen peroxide and $0.05 \%(\mathrm{w} / \mathrm{v})$ diaminobenzidine tetrat hydrochloride (DAB, Serva, Heidelberg, FRG) in Tris-HCl buffer (pH 7.6) and the sections were counterstained with hematoxylin. Specificity of the immunolocalization was assessed by applying preimmune serum on parallel sections as negative control and by using human kidney cortex sections, with a well documented ADCP immunoreactivity pattern, as positive control. In order to enhance the intensity of the DAB stain $0.01 \mathrm{M}$ imidazole was added to the DAB substrate solution (22).

\subsection{Results}

\subsubsection{RIA}

The soluble ADCP content was quantified in 18 different tissues derived from up to 9 individuals (Table I). We observed a considerable donor to donor variation in the ADCP content of several tissues. For instance, in the duodenum the values ranged from 42 to 462 and in ileum even from 14 to $1,017 \mathrm{ng} / \mathrm{mg}$ protein. The prostate showed the highest specific content of ADCP in its cytosol $(4,177 \mathrm{ng} / \mathrm{mg}$ protein). The next highest was the renal cortex $(1,882 \mathrm{ng} / \mathrm{mg}$ protein). Rather high quantities of soluble ADCP were observed also in the renal medulla, the skin and the mucosa of the intestinal tract. Very low amounts, around the detection limit, were seen in breast tissue and erythrocytes.

A comparison of the quantities of ADCP in the soluble and membrane fractions in various tissues is shown in Table $I I$. The ADCP quantity in the membrane fraction was always considerably higher than that observed in the cytoplasm. This ranged from a factor of 2 in the stomach to a factor of about 15 in colon and spleen. Very high quantities of ADCP were found in the membrane fractions of renal cortex and prostate. The amount of ADCP in the membrane fraction of erythrocytes was below 
Table I Soluble ADCP in human tissues

\begin{tabular}{|c|c|c|c|c|}
\hline \multirow[t]{2}{*}{ Tissue } & \multicolumn{3}{|c|}{ ADCP $n g / m g$ protein } & \multirow[t]{2}{*}{ Range } \\
\hline & Mean & SD & $N$ & \\
\hline Skin & 128 & 123 & (5) & $25-$ \\
\hline \multicolumn{5}{|l|}{ Kidney } \\
\hline cortex & 1,882 & 327 & (7) & $1,596-2,393$ \\
\hline medulla & 362 & & (2) & 97. 627 \\
\hline Liver & 66 & & (3) & $51-$ \\
\hline Stomach & 23 & 22 & (4) & 8 \\
\hline Duodenum & 180 & 132 & (9) & 42. $\quad 462$ \\
\hline Jejunum & 236 & 201 & (8) & $78-680$ \\
\hline Ileum & 295 & 294 & (8) & $\mathbb{1 4}-\mathbb{1 , 0 1 7}$ \\
\hline Cecum & 237 & 297 & (8) & $38-920$ \\
\hline Colon & 69 & 14 & (8) & 11 - \\
\hline Rectum & 109 & 165 & (9) & 16 \\
\hline Lung & 54 & 60 & (5) & 156 \\
\hline Pancreas & 51 & 20 & (5) & $22-$ \\
\hline Prostate & 4,177 & 5,532 & (9) & $184-17,989$ \\
\hline \multicolumn{5}{|l|}{ Endometrium } \\
\hline proliferative & 59 & 51 & (5) & 19 \\
\hline secretory & 381 & 182 & (4) & $204-$ \\
\hline Urinary bladder & 18 & & (3) & 6 \\
\hline Mammary gland & 7 & & (2) & $5-$ \\
\hline Spleen & 34 & 7 & (5) & 27 \\
\hline Thymus & 47 & 20 & (4) & $23-$ \\
\hline Erythrocyles & nd & & (2) & \\
\hline
\end{tabular}

$\mathrm{SD}=$ Standard deviation

$\mathrm{N}=$ Number of samples from different individuals

1 Total (soluble + membrane) ADCP ng/mg protein nd $=$ Not detectable

the detection limit. The influence of post mortem autolysis was investigated by immunohistochemistry applied on human kidney cortex samples. After storage for up to $30 \mathrm{~h}$ at RT the ADCP specific immunoreactivity pattern was still observed (not shown).

\subsubsection{Immunohistochemistry}

\section{Skin}

Immunoperoxidase staining revealed ADCP reactivity in the luminal membranes of acinar cells of serous sweat glands. Dermal fibroblasts were also positive. Melanocytes, sebaceous glands and hair follicles were negative.

\section{Kidney}

Very strong immunoreactivity was found in the brushborders of the epithelial cells 
Table II ADCP quantities in the solubie (S) and membrane (M) fractions of direan hissues collected post horten from one autopsy

\begin{tabular}{|c|c|c|}
\hline \multirow[t]{2}{*}{ Tissue } & \multicolumn{2}{|c|}{ ADCP (ng/mg protein) } \\
\hline & $s$ & $\mathrm{M}$ \\
\hline Skin & 303 & 3,119 \\
\hline \multicolumn{3}{|l|}{ Kidney } \\
\hline cortex & $1.882 \pm 327(7)^{4}$ & $10,498 \pm 5,360(7)^{8}$ \\
\hline medulla & 97 & 723 \\
\hline Liver & 51 & 280 \\
\hline Stomach & 30 & 66 \\
\hline Drodenum & 158 & 2,014 \\
\hline Jejunums & 321 & 2,146 \\
\hline Heum & 397 & 2,802 \\
\hline Cecum & 134 & 787 \\
\hline Colon & 143 & 2,141 \\
\hline Rectum & 63 & 405 \\
\hline Lung & 156 & 323 \\
\hline Pancreas & 64 & 310 \\
\hline Prostate & $4,177 \pm 5,532(9)^{3}$ & $14,573 \pm 15,696(9)^{1}$ \\
\hline Urinary bladder & 20 & 63 \\
\hline Spleen & 37 & 508 \\
\hline Erythrocytes & nd & nd \\
\hline
\end{tabular}

- Mean $\pm \mathrm{SD}$ of $(\mathrm{n})$ samples. All the other tixsues were obtaned from a single atupsy nd $=$ Not detectable

of the proximal convoluted tubules in the cortex. Glomeruli, distal tubules, endothelium and erythrocytes were negative (Fig. I).

\section{Liver}

In the hepatocytes the immunoreactivity showed a diffuse cytoplasmic as well as a membrane associated pattern. Bile canaliculi in the central lobular areas were positive. Bile ducts and blood vessels were not stained (Fig. 2).

\section{Small intestine}

In duodenum, jejunum and ileum the striated border of columnar cells on the villi stained intensely for ADCP. The staining was apparent from the top to the base of the villi. Immunoreactivity was also observed in large cytoplasmic granules in the mucosal columnar cells. Goblet cells were negative. Immunoreactivity was also observed in mononuclear cells in the lamina propria (Fig. 3). 

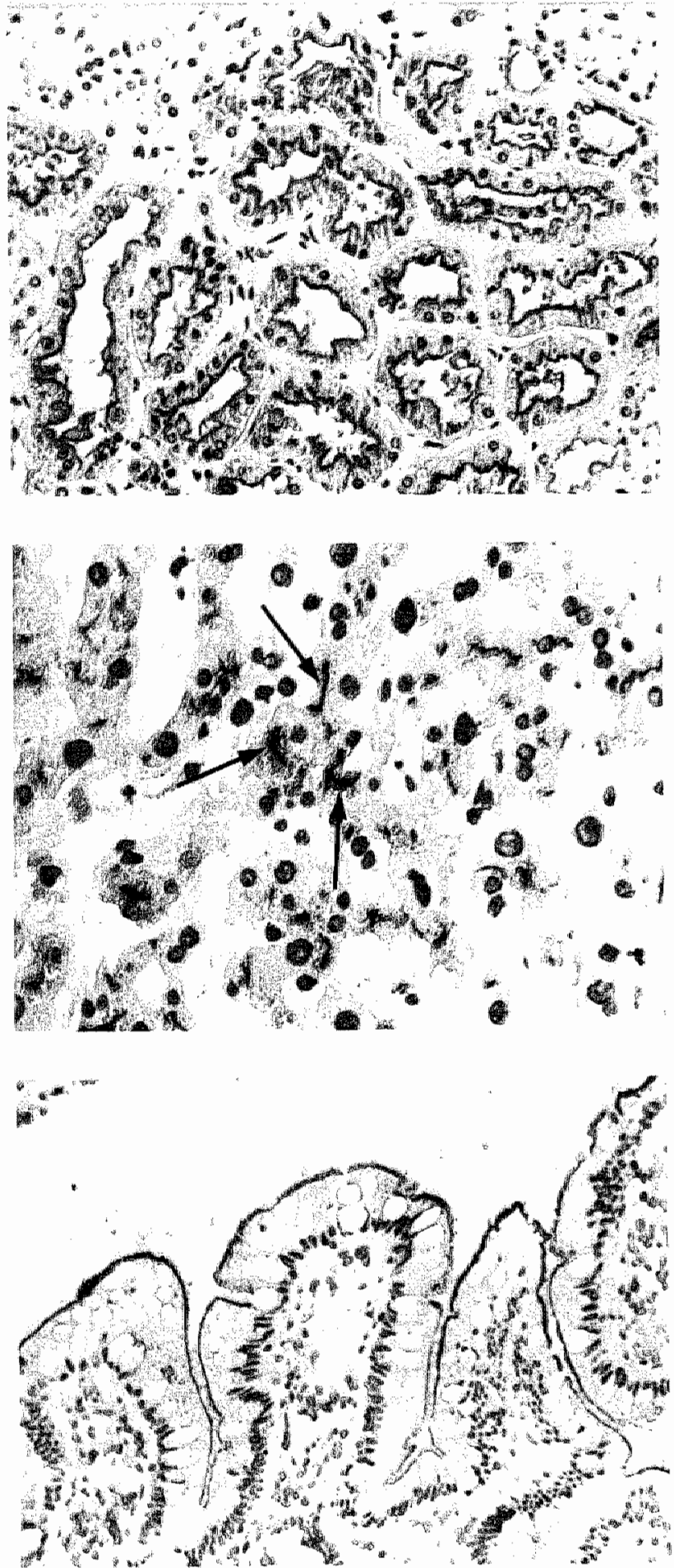

Fig. 1. Brushborder associated ADCP immunoreactivity in renal proximal tubular epithelium (paraffin section, immunoperoxidase, $180 \times$ ).
Fig. 2. Bile canalicular ADCP immunoreactivity (arrow) in liver (frozen section, immunoperoxidase, $400 \times)$.
Fig 3. Brushborder associated $\mathrm{ADCP}$ immunoreactivity in ileal mucosa (paraffin section, immunoperoxidase, $160 \times)$. 
Fig. 4. Columnar cell apical membrane associated ADCP immunoreactivity in colonic mucosa (frozen section, immunoperoxidase, $300 \times$ ).

Fig. 5. Luminal membrane associated ADCP im-

munoreactivity of the serous glands in the trachea (frozen section, immunoperoxidase, $250 \times$ ).

Fig. 6. Diffuse cytoplasmic and membrane associated $A D C P$ immunoreactivity in type I (arrow) and type II (arrowhead) pneumocyles in the lung (paraffin section, immunoperoxidase, $550 \times$ ).
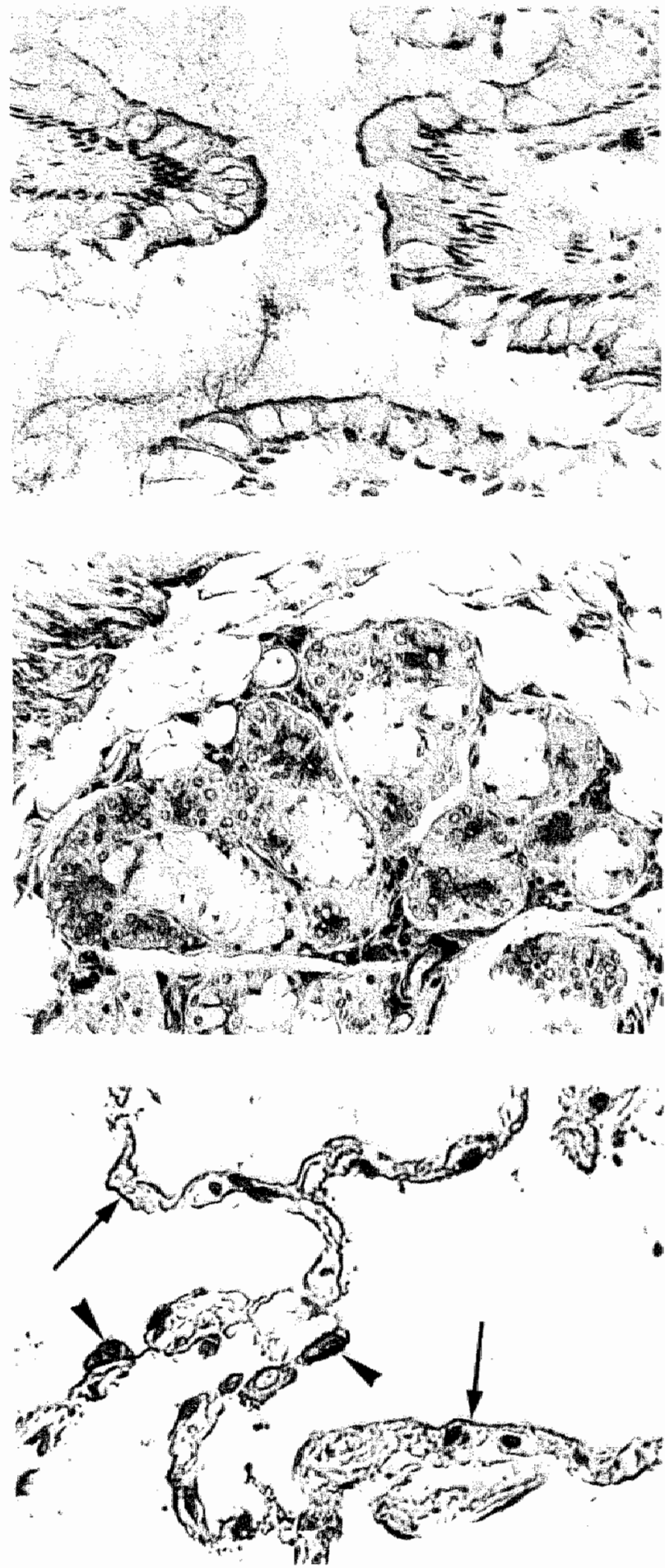

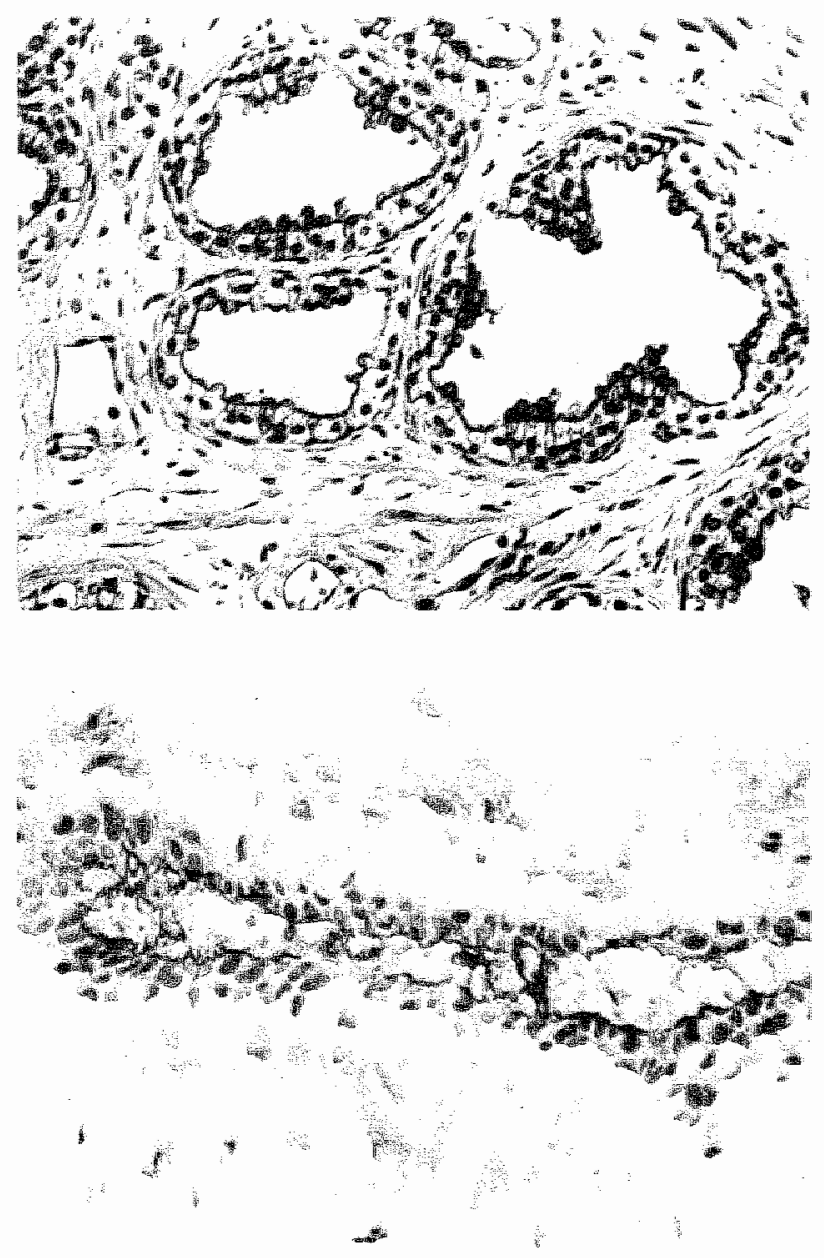

Fig. 7. Apical membrane, apical cytoplasm and secretory vesicle associated ADCP immunoreactivity in prostatic glandular epithelial cells (paraffin section, immunoperoxidase, $200 \times$ ).

Fig. 8. Luminal membrane associated $\mathrm{ADCP}$ immunoreactivity in the breast (frozen section, ümmunoperoxidase, $400 \times$ ).

Fig. 9. Luminal membrane associated ADCP immunoreactivity in secretory endometrium (frozen section, immunoperoxidase, $450 \times)$. 


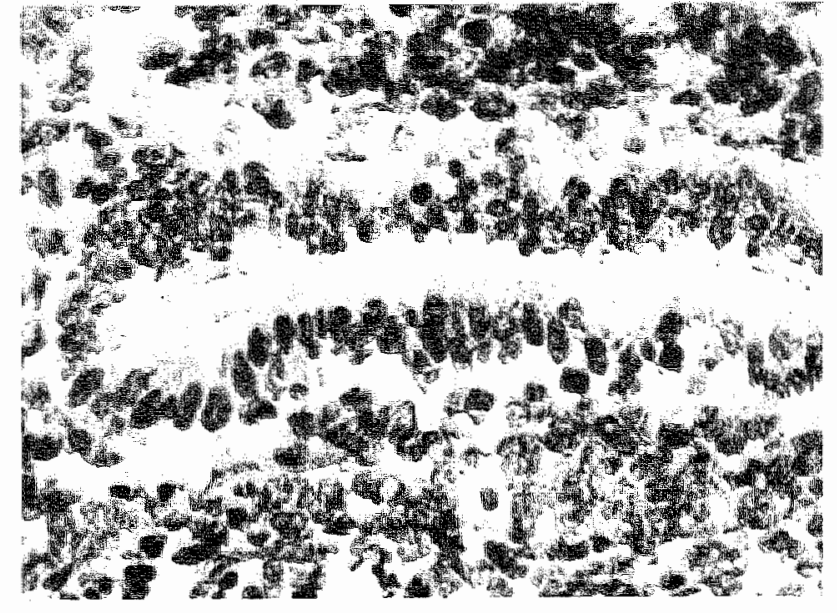

Fig. 10. Absence of ADCP immunoreactivity in prolile. rative endometrium frozen section, immunoperoxidase, $450 \times)$.

\section{Large intestine}

In the mucosa of different parts of the large intestine (cecum, colon, rectum) ADCP was detected mainly in the brushborder region of the luminal columnar epithelial cells. In the crypt epithelium and in goblet cells no immunoreactivity was found. Again, mononuclear cells in the lamina propria were positive (Fig. 4).

\section{Trachea}

ADCP immunoreactivity was found in the serous tracheal glands confined to the luminal plasma membranes of the epithelial cells. The epithelium of mucinous glands and ciliated epithelium were negative (Fig. 5).

\section{Lung}

In the lung type I pneumocytes showed diffuse cytoplasmic staining in combination with membrane associated immunoreactivity, whereas the surfactant producing pneumocytes type 11, identified by the periodic acid Schiff (PAS) reaction, showed strong cytoplasmic and weak membrane associated immunoreactivity (Fig. 6).

\section{Pancreas}

$\mathrm{ADCP}$ immunoreactivity in the pancreas was confined to the luminal membranes of the epithelial cells of the intra- and interlobular ducts. Islets of Langerhans and pancreatic acini were negative.

\section{Prostate gland}

Very strong ADCP immunoreactivity was found in the apical membrane and apical cytoplasm of the glandular epithelial cells and in the secretory vesicles and secretory fluid. Flattened glandular epithelial cells, obviously inactive, showed no or only weak ADCP immunoreactivity. The fibromuscular stroma was negative (Fig. 7). 


\section{Sallivary gland}

In the salivary gland the luminal membranes of the serous glans showed ADCP immunoreactivity whereas the mucinous glands were negative.

\section{Gall bladder}

Staining in the wall of the gall bladder was confined to the luminal plasma membrane of the diverticular epithelial cells. No immunoreactive material was found in the fibromuscular layer.

\section{Mammary gland}

ADCP immunoreactivity was found in the luminal membranes of the epithelial cells of the lobular acini and ducts (Fig. 8).

\section{Uterus}

In secretory endometrium ADCP immunoreactivity was found in most endometrial glands. The staining was confined to the luminal membranes of secretory epithelial cells and to the secretory fluid (Fig. 9). No staining was observed in proliferative endometrium (10.10). The endometrial stroma and the myometrium were negative. In the cervix the endocervical glandular epithelial cells showed strong immunoreactivity at the luminal membranes.

\section{Placenta}

Weak apical membrane associated immunoreactivity was observed in the syncytial trophoblasts.

\section{Other tissues}

No ADCP specific immunoreactive staining was found in stomach, testis, seminal vesicles, thyroid gland, urinary bladder or ovary.

\subsection{Discussion}

The physiological function of ADCP is still obscure. It has been suggested that its capacily to bind ADA-S may be its major rolle $(23)$. We $(4,24)$ and others $(1-3$, 5,23 ) have demonstrated that membrane associated ADCP is not completely saturated with $\mathrm{ADA}-\mathrm{S}(1,25,26)$. It has been shown that this membrane bound $\mathrm{ADCP}$ still has the capacity to bind ADA-S $(3,24,25)$. Membrane bound ADCP therefore, by binding ADA to the plasma membrane, may function in the metabolism of adenosine and deoxyadenosine (1-3). Membrane ADCP might also serve as a receptor for the recovery or removal of free $\mathrm{ADA}-\mathrm{S}$ released into the circulation by events such as cell turnover $(1,7,25)$. It has been shown that in various tissues $(1,25,26)$, including human T-lymphoid cells (24), a correlation between the quantities of ADA-S and ADCP does not exist. By immunohistochemistry ADA-S and 
ADCP were not co-localized in rabbit brain neurons (27).

Against this background we decided to analyze quantitatively as well as qualitativaly the presence of ADCP in various human tissues. In some tissues considerable interindividual variation in the soluble ADCP content was demonstrated as determined by RIA. This may be an artefact, due to differences in autolysis between various tissue samples, as is exemplified by the wide range of values found in the different parts of the small intestime, an organ with very rapid autolysis. Alternatively, it is conceivable that between different individuals differences in ADCP levels exist. Finally, the detected variation might be a reflection of tissue heterogeneity. Our histochemical results did show tissue heterogeneity e.g. in the mammary gland and in the pattern of bile canalicular staining in the liver. On this basis different samples of the same tissue may show different amounts of ADCP.

Table II shows that ADCP is mainly associated with membranes. The amounts observed in the membrane fractions invariably appeared to be much higher than in the soluble fractions. The immunohistochemical observations supported the predominant membrane associated localization of the protein. These results are in good agreement with other immunohistochemical and biochemical findings in human kidney $(1,4,6)$, lung $(1,6)$, liver (1), spleen (1), thymus (1), prostate (6), small and large intestine $(4,6)$, breast (6), placenta $(2,6)$ and skin fibroblasts (3). However, in contrast to the literature, ADCP was not detected in skin melanocytes (28). This can be due to the presence of a different molecular form of ADCP in these cells which is not recognized by our antiserum.

Our immunohistochemical and biochemical data demonstrate that ADCP is predominantly present in absorptive epithelia and in exocrine glands, especially at the absorptive or secretory apex of the cell. The fact that ADCP has been found in human secretions such as saliva, tears, urine, plasma (7-9) and semen (Dinjens et al., unpublished results); our immunohistochemical and biochemical findings that in the endometrial glands ADCP is present in secretory epithelium exclusively during the secretory phase; and our immunohistochemical demonstration of extensive ADCP expression in the prostatic secretory vesicles and secretory fluid, supports the suggestion that ADCP is a secretory protein $(5,7)$. The expression of ADCP in the cytoplasm was not only demonstrated biochemically (Table I and $\rrbracket$ ) but also im. munohistochemically e.g. in lung, liver and prostate. These results contest the suggestion by Andy and Kornfeld (17) that soluble ADCP results from proteolysis of the membrane form, during preparation of the tissue extracts.

These findings are largely in agreement with ours in mouse and rat (29) and with those of Schrader and West (15), in the rabbit. Some differences were apparent, which point to species differences in ADCP expression. In favor of this suggestion evidence was presented by Schrader and Bryer (1) and Schrader et al. (23). They demonstrated that using the same goat anti-rabbit ADCP antiserum the human glomeruli did not show immunoreactivity whereas the rabbit glomeruli were posi. tive. An alternative possibility might be the existence of molecular differences between human and rabbit ADCP. This explanation is supported by our inability to 
get completely identical immunoreactivity patterns with our anti-human ADCP antiserum on rabbit tissues to those described by Schrader and West (5) with their antirabbit $\mathrm{ADCP}$ antiserum (results not shown).

In summary, we found membranous localization of ADCP in high quantities in the human kidney, prostate and intestinal tract by biochemical as well as by immuno. histochemical methods. The immunoreactivity patterns largely correspond with those in the rabbit, mouse and rat. Our findings indicate that the presence of ADCP might be related to the secretory and/or absorptive process. Its physiological funclion, however, remains obscure.

\subsection{References}

1. Sithrader WP. Bryer PJ (1982) Characterization of an insoluble adlenosine deaminase complexing protein from human kidney. Arch. Biochem. Biophys. 215: 107-115.

2. Trotua $\mathrm{PP}(1982)$ Identification of a membrane associated adenosine deaminase binding protein from human placenta. Biochemistry 21: 4014-4023.

3. Andy RJ, Kornfeld R (1982) The adenosine deaminase binding protein of human skin fibroblasts is lowated on the cell surface. J. Biol. Chem. 257: 7922-7925.

4. Ten Kate J, Wijnen JT, Boldewijn J, Meera Khan P, Bosman FT (1985) Immunohistochemical localization of adenosine deaminase complexing protein in intestinal mucosa and in colorectal adenocarcinomas as a marker for tumour cell theterogeneity. Histochem, $J, 17: 23 m 31$.

5. Schradler WP, West CA (1985) Adenosine deaminase complexing proteins are localized in exocrine glands of the rabbit. J. Histochem. Cytochem. 33: 508-514.

6. Finsud CL, Cordon Cardo C, Bander NH, Whitmore WF, Melamed MR, Old LJ (1985) Sprecificity analysis of mouse monoclonal antibodies defining cell surface antigens of human renal cancer. Proc. Natl. Acad. Sci. USA 82: 2955-2959.

7. Schrader WP, Woodward FJ, Pollara $B(1979)$ Purification of an adenosine deaminase complexing protein from human plasma. J. Biol. Chem. 254: 11964-11968.

8. Schrader WP. Stacy AR (1979) Immunoassay of the adenosine deaminase complexing protens of fuman dissues and body fluids. J. Binol. Chem. 254: 11958-11963.

9. Thompson RE, Piper D., Galberg C, Chan TH, Tolkofr-Rubin NF, Rubin RH (1985) Adenosine deaminase binding protein, a new diagnostic marker for kidney disease. Clin. Chem. 31: 679-683.

10. Nishiltara $H$, Ishikawa $S$, Shinkai K. Akedo $H$ (1973) Multiple forms of human adenosine deaminase. 11. Isolation and properties of a conversion factor from human lung. Biochim. Biophys. Acta 302: $429-442$.

11. Trotia PP, Balis ME (1978) Characterization of adenosine deaminase from normal colon and colon tumors. Evidence for tumor specific variants. Biochemistry 17: 270-268.

12. Herbschleb-Voog E, ten Kate J, Meera Khan P (1983) Adenosine deamimase complexing protein: A tranformation sensilive protein with potentials of a cancer marker. Anticancer Res. 3: 95-100.

13. Ten Kate J, Wijnen JT, Herbschleb-Vooge E, Griffioen G, Bosman FT, Meera Khan P. Specific isozyme profiles of adenosine deaminase in colorectal adenocarcinoma. In: Selected topies in clinical enxymology, (Goldberg D and Werner M, eds.) Walter de Griyter, New York, 1983, pp. $11-27$. 


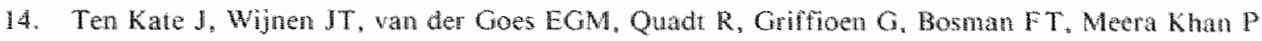
(1984) Quartitum changes in adenosine deaminase isozymes th human colorectal adenoctrenomas. Cancer Res. 44: $4688-4692$.

15. Inwood M, Povey S, Delharty JDA (1980) Comparison of isozymes in fetal adult and iranstorned Thbroblasts. Cell Bol. Int. Rep. $4: 327-335$.

16. Ruzky LP, Siciliano MJ (1982) Various isozyme gene expression patems ariong human colorochal adenocarcinoma coll hines and tissues. I. Natl. Cancen Inst. 68:81-90.

17. Wright WC, Daniels WP, Fogh J (1981) Distinction of seventy-one cultured human tumor cell tines by polymorphic enzyme analysis. I. Natl. Cancer Inst. $66: 239-247$.

18. Daddona PE, Frohman MA, Kelley WN (1979) Radioinnumochemical quantification of human adenosine daminase. J. Chin. Invest. 64: 798-803.

19. Chechit BE, Madapallimatiam A, Gelfand EW (1979) Radiommunoassay for human thymus leukemia associated antigen. J. Natl. Cancer Inst. 62:465-470.

20. Lowry OH, Rosebrough NJ, Fart AL, Randall RJ (1951) Protein measurements with Folin phenol reagent. J. Biol. Chem. 193: 265-275.

21. Mollean IW, Nakane PK (1974) Periodate-lysinemaraformaldehye fixative. A new fixative for im munoelectronmicroscopy. J. Histochem. Cytochem. 22: 1077.

22. Sirauss $W(1982)$ Imidazole hncreases the sensitivity of the cylochemical reaction for peroxidase with diaminobenzidine at a neutral $\mathrm{HH}_{\mathrm{H}}$ J. Histochem. Cytoghern, 30: 49l-493.

23. Schrader WP, Harder CM, Schrader DK (1983) Adenosine deminase complexing profeñs of uhe rabbit. Comp. Biochem. Physiol. 75B: 119-126.

24. Dinjens. WNM, Van der Boon I, Ten Kate J, Zeijlemaker WP, De Bruin CHMM, Bosman II, Meera Khan $\mathbb{P}$ (1986) Cell surface adenosine deaminase (ADA) and its complexing protein (ADCP) in human T-lymphoid cells. Adv. Exp. Med. Biol. 95B: 407-414. (This thesis Chapter 5).

25. Schrader WP, Harder CM, Schrader DK. West CA (1984) Metabolism of several molecular for tus of ademosine deaminase intraveneously infused into the rabbit. Arch. Biochem. Bioplyys. 230: 158-167.

26. Van der Weyden MB, Kelley WN (1976) Human adenosine deaminase: distribuinon and properties. J. Biol. Chem. 251: $5448-5456$.

27. Schrader WP, West CA, Strominger NL (1987) Localization of adenosine deaminase and adenosine deaminase complexing protein un rabbit brain. J. Histochem. Cytochem. 35: 443-451.

28. Houghton AN, Abino AP, Cordon-Cardo C, Davis L.J, Eisuger M (1988) Cell surface antigens of thuman metarnoytes and melanoma. I. Exp. Med, 167: 197-212.

29. Dinjens, WNM, ten Kate J, Wijnen IT, Signet CM, Buek C, wan der Linden EPM, Mcera Khan $\mathrm{P}$, Bosman F"T (1988) Discribution of adenosine deaminase complexing proteins (ADCP) in murine vissues. Submited for publication (This whesis Chapter 3). 



\section{Immunocytochemical demonstration of adenosine deaminase (ADA) and adenosine deaminase complexing protein (ADCP) on human T-lymphoid cells*}

\subsection{Introduction}

Adenosine deaminase (ADA, EC no. 3.5.4.4), the enzyme which catalyses the irreversible conversion of adenosine and deoxyadenosine to inosine and deoxyinosine respectively, plays an important role in the development of the immune system. The enzyme ADA is probably involved in both $B$ and $T$-lymphocyte differentiation in man because an inherited ADA deficiency is causally associated with severe combined immunodeficiency disease (1). Increased amounts of the substrates of ADA are generally thought to play a role in the etiology of this disease (2).

Two electrophoretically distinguishable molecular weight forms of ADA are known to occur in man and they are designated as ADA-S and ADA-L. The small isozymic form (ADA-S) is a monomer with a molecular weight of about $43 \mathrm{kD}$. The large form (ADA-L) with a molecular weight of about $280 \mathrm{kD}$ is composed of one homodimeric molecule of ADA complexing protein (ADCP) and two molecules of ADA-S. ADA-S can be converted to ADA-L by complexing with ADCP (3). ADCP was initially described as a soluble glycoprotein (4-6) and subsequently found to be predominant in plasma membranes (7-11).

In a number of studies ADA was reported to be partly associated with the plasma membrane $(8,11-16)$ and evidence was presented that membrane ADA displays its enzymatic activity extracellularly $(17,18)$ The main function assigned to ADA in lymphoid cells is the protection of these cells from the toxic effects of elevated levels of adenosine and deoxyadenosine (19). In the present study we investigated the occurrence of $\mathrm{ADA}$ and $\mathrm{ADCP}$ on the outer surface of human T-lymphoid cells by immunocytochemistry.

* Based on: Dinjens WNM, van der Boon 1 , ten Kate I. Zejjlemaker WP, De Bruijn CHMM, Bosman FT, Meera Khan $P(1986)$. Cell strface acenosine deaminase (ADA) and its complexing protein (ADCP) in human T-tymphoid cells. Adv. Exp. Med. Biol. 195B: 407-414. 


\subsection{Materials and Methods}

\subsubsection{Preparation of cell suspensions}

Human peripheral blood mononuclear cells (MNC) were isolated from the blood of normal healthy donors by centrifugation over Percoll. $\left(\mathrm{d}=1.076 \mathrm{~g} / \mathrm{cm}^{3}\right.$; Pharmacia, Uppsala, Sweden). Contaminating platelets were removed by two low-speed washing steps and erythrocytes were lysed with ice-cold ammoniumchloride solution. Human peripheral blood T lymphocytes (PBL-T) were obtained by nylon wool filtration of the MNC (20). The final cell suspension contained more than $90 \% \mathrm{E}$ rosette-forming cells.

Human thymocytes were prepared as described by Astaldi et al. (21). Thymus tissue was obtained from children undergoing cardiac surgery. After removal of fat, connective tissue and blood vessels, the fragments were cut into small pieces and gently pressed through a metal sieve. The thymocytes were washed in phosphate buffered saline (PBS).

\subsubsection{Antisera and monoclonal antibodies}

Specific anti-human ADA-S and anti-human ADCP antisera were raised in rabbits $(22,23)$. The anti-ADA-S antiserum detects free ADA-S as well as ADA-S bound to $\mathrm{ADCP}(\mathrm{ADA}-\mathrm{L})$. The anti-ADCP antiserum detects free ADCP as well as ADCP complexed with ADA-S, but does not recognize ADA-S (23). Fluorescein isothiocyanate labeled goat anti-rabbit IgG immunoglobulins (G/R FITC) were obtained from Nordic Immunological Laboratories, Tilburg, The Netherlands. Phycoerythrin (PE) conjugated monoclonal antibodies anti-Leu-1 (anti-CD5), antiLeu-2a (anti-CD8) and anti-Leu-3a (anti-CD4), reactive with all $\mathrm{T}$-cells, $\mathrm{T}$ cytotoxic/suppressor cells and $\mathrm{T}$-helper/inducer cells respectively, were purchased from Becton and Dickinson, Sunnyvale CA, USA.

\subsubsection{Flowcytometry}

About $10^{\circ}$ cells were incubated with normal rabbit serum (NRS), anti-ADA or anti-ADCP antiserum for 1 h at $4^{\circ} \mathrm{C}$. The cells were washed once and incubated $(1$ $h, 4^{\circ} \mathrm{C}$ ) with a combination of $\mathrm{G} / \mathrm{R}-\mathrm{FITC}$ and $\mathrm{PE}$ conjugated anti-CD5, anti-CD8 or anti-CD4 after which the cells were washed twice. Optimal dilutions of the antisera, G/R-FITC and monoclonal antibodies were prepared in PBS containing $0.5 \%$ (w/v) bovine serum albumin (RIA grade; Sigma, St. Louis MO, USA) and $0.01 \%(\mathrm{w} / \mathrm{v})$ sodium azide. The cells also were washed in this solution.

To investigate the binding of ADA-S to lymphoid cells we incubated these cells with a lysate of human erythrocytes before incubation with antiserum. We used the erythrocyte lysate because human erythrocytes contain only ADA-S and are completely devoid of ADCP (and ADA-L) (24). 
Fluorescence intensity of viable lymphocytes was measured with a fluorescence activated cell sorter (FACS IV, Becton and Dickinson). Contaminating non-viable lymphocytes, monocytes and cell debris were gated out electronically. The percentage of fluorescence positive cells was calculated from the flworescence histogram as follows. For the histograms obtained from incubation with anti-CD5-PE, antiCD8-PE or anti-CD4-PE a clear distinction between positive and negative cells was possible (Figs. 1-3) and the threshold was set at the minimum between the two populations. The cells with fluorescence intensity exceeding the threshold were regarded as positive. For the calculation of the percentage anti-ADA and anti-ADCP positive cells the histogram obtained with NRS was used to determine the threshold. Double fluorescence (FITC and PE) was measured by gating out the PE negative cells and determining the FITC fluorescence intensity of the PE positive cells.

\subsubsection{Statistical evaluation}

The data were statistically analyzed with Student's t-test.
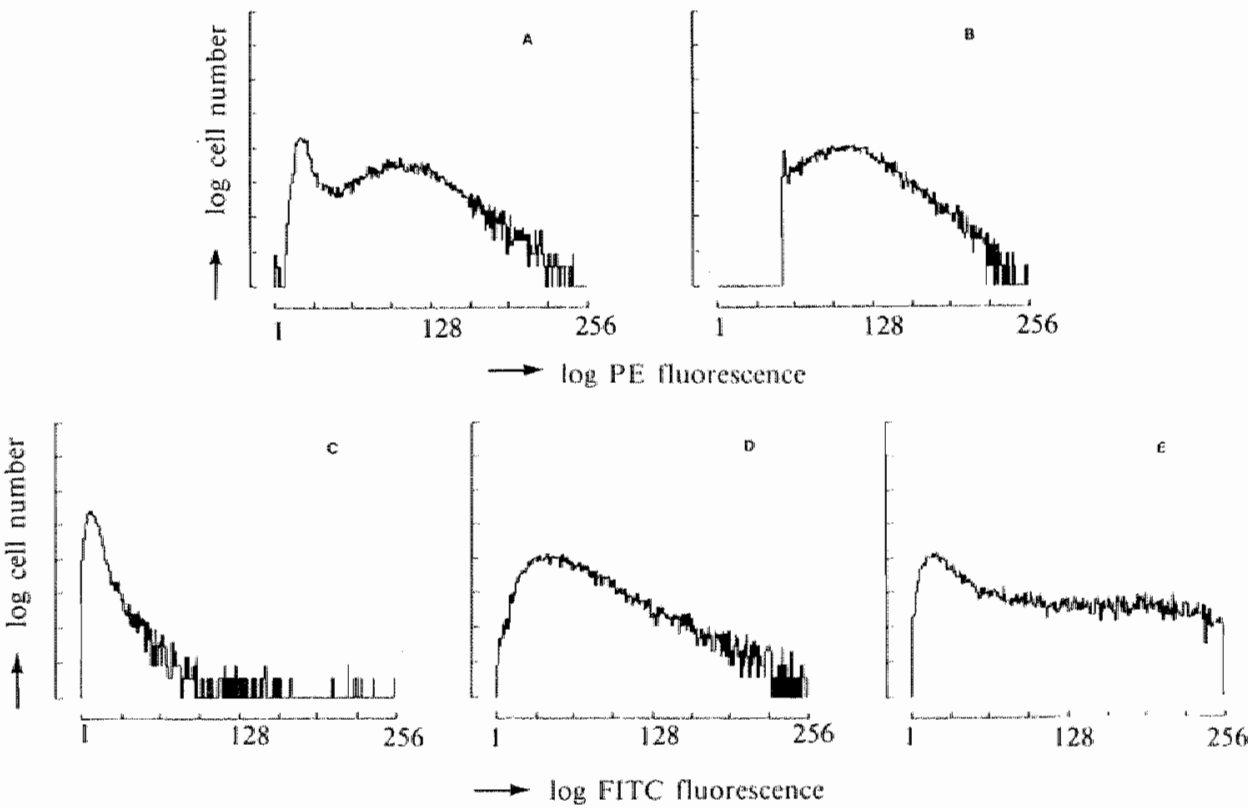

Fig. 1. Fluorescence histograms

A. MNC incubated with anti-CD5-PE; B. CDS positive population; $C$. NRS control of $B$;

D. Anti-ADA of $B$; E. Anti-ADCP of B. 

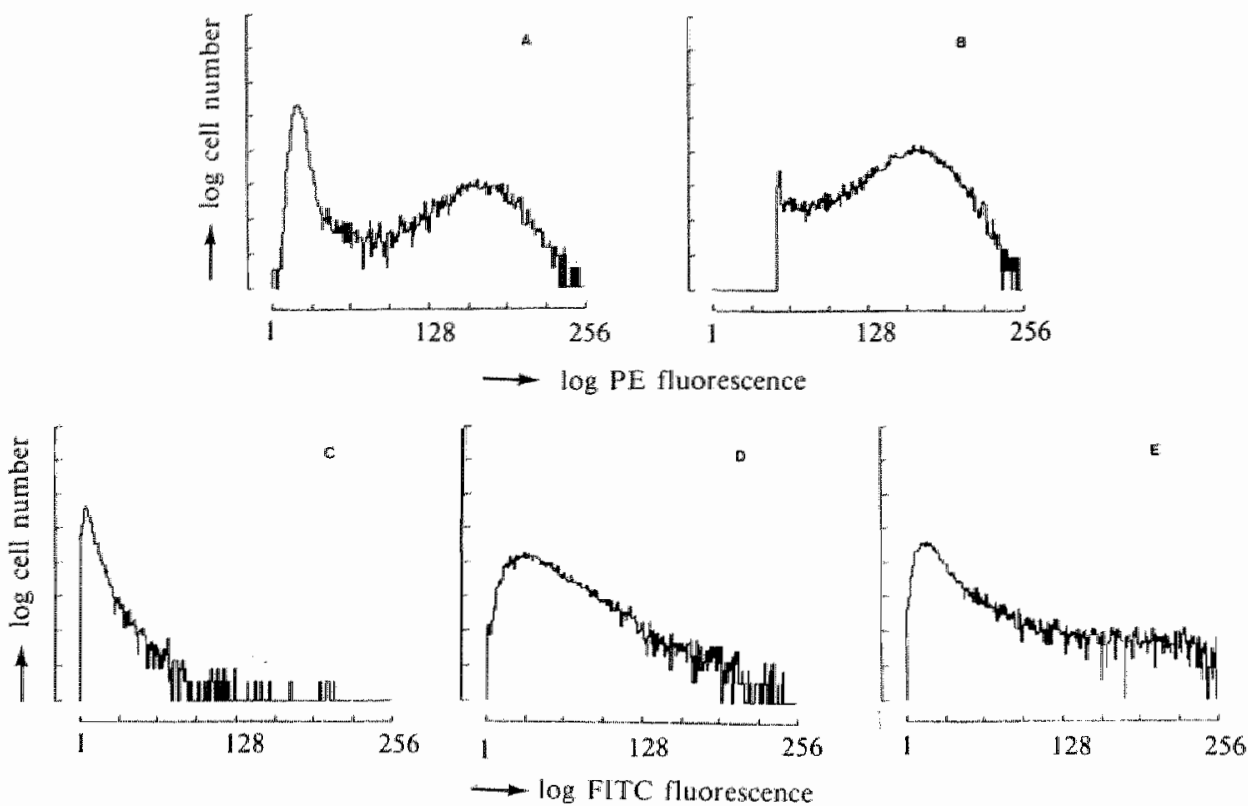

Fig. 2. Fluorescence histograms

A. MNC incubated with anti-CD8-PE; B. CD8 positive population; $\mathrm{C}$. NRS control of $\mathrm{B}$; D. Anti-ADA of B; E.Anti-ADCP of B.
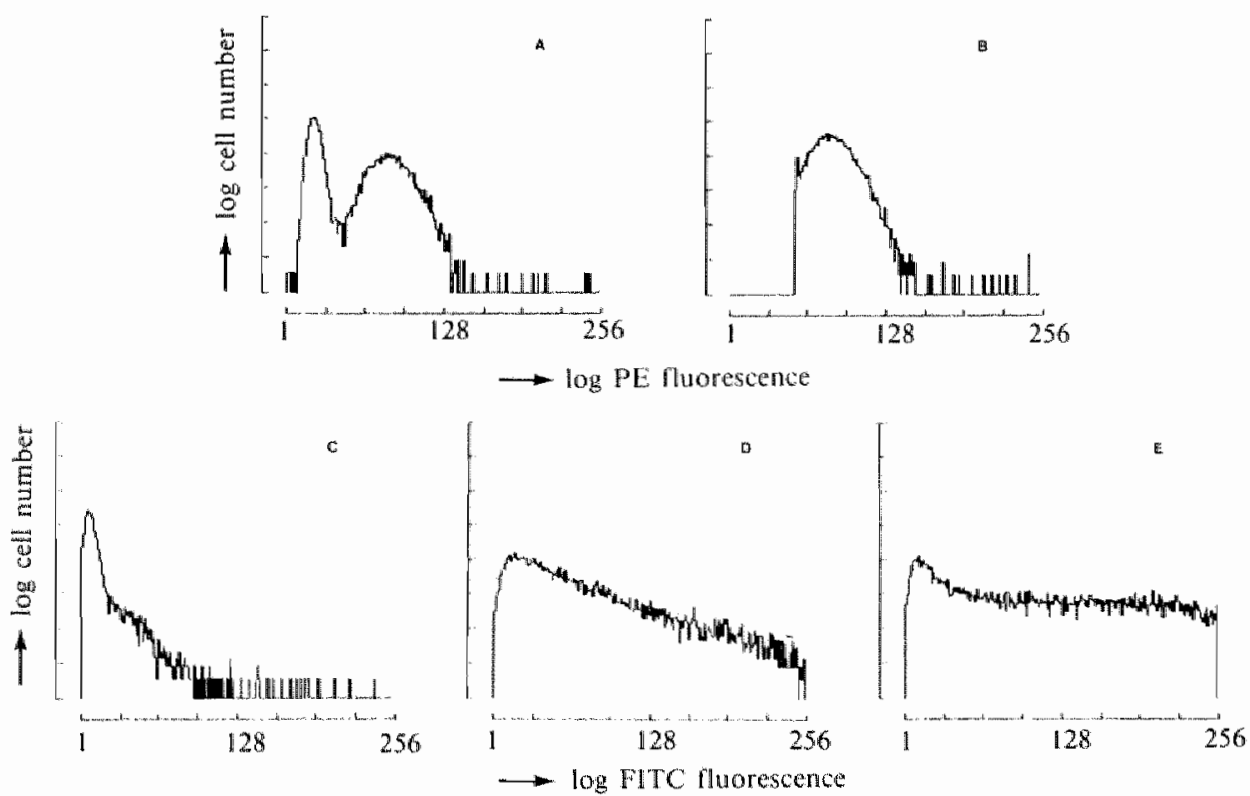

Fig. 3. Fluorescence histograms

A. MNC incubated with anti-CD4-PE; B. CD4 positive population; C. NRS control of B; D. Anti-ADA of $B ; \mathbb{E}$. Anti-ADCP of $B$. 


\subsection{Results}

The results of a representative experiment are shown in Figs. 1-3. In Fig. 1A the fluorescence histogram of MNC incubated with anti-CD5 is shown. In this experiment $75 \%$ of the cells were CD5 positive. Of the CD5 positive population (Fig. 1B) the histograms obtained after incubation with NRS, anti-ADA or anti-ADCP antiserum are shown in Figures $1 \mathrm{C}, 1 \mathrm{D}$ and $1 \mathrm{E}$ respectively. Of the CD5 positive cells $15 \%$ was anti-ADA and $48 \%$ was anti-ADCP positive. The MNC population contained 28\% CD8 positive cells (Fig. 2A) and of this population (Fig. 2B) 12\% of the cells were anti-ADA (Fig. 2D) and 29\% anti-ADCP positive (Fig. 2E) in comparison with the NRS control (Fig. 2C). Of the MNC, 48\% was CD4 positive (Fig. $3 \mathrm{~A}$ and $3 \mathrm{~B}$ ). The CD4 positive population contained 14\% anti-ADA (Fig. 3D) and $54 \%$ anti-ADCP positive cells (Fig. 3E). In Fig. 4 the results are shown of 8 experiments with human $\mathrm{MNC}$. The MNC populations contained an average percentage of $71 \pm 8 \mathrm{PBL}-\mathrm{T}$ (CD5 positive); $47 \pm 4$ being of T-helper/ inducer type (CD4 positive) and $27 \pm 5$ of T-cytotoxic/suppressor type (CD8 positive). The PBL-T populations contained a percentage of $21 \pm 6$ membrane ADA positive cells and $47 \pm 10$ membrane ADCP positive cells.

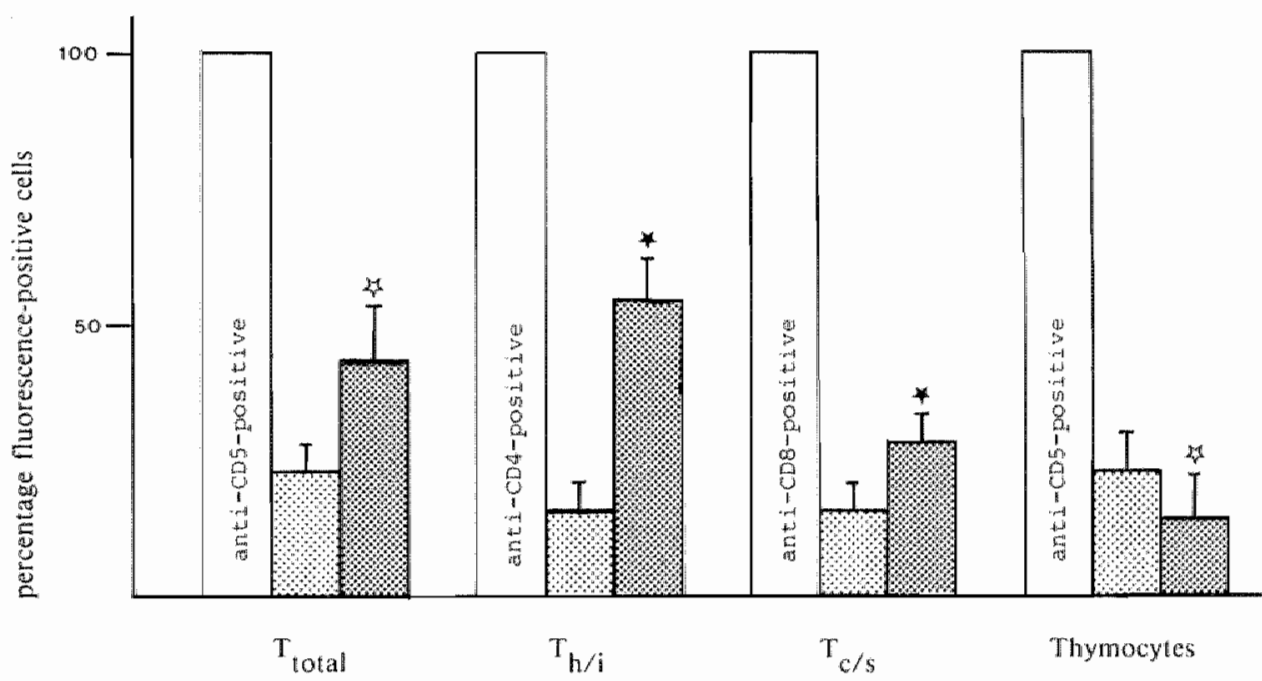

Fig. 4. Percentage anti-ADA and anti-ADCP 20 positive PBL $-\mathrm{T}(\mathrm{n}=8)$, Thelper/inducer $(n=8), T$ cytotoxic/suppressor $(n=8)$ and thymocytes $(n=4)$

in significantly different $\mathrm{p}<0.001$

* significantly different $\mathrm{p}<0.001$ 
A highly significant $(p<0.001)$ difference was observed between the percentage membrane ADCP positive T-helper/inducer cells $(55 \pm 7)$ and T-cytotoxic/suppressor cells $(28 \pm 5)$, whereas in both populations a percentage of $17 \pm 5$ of the cells displayed membrane ADA expression (Fig. 4). In 4 experiments with human thymocytes a percentage of $20 \pm 7$ of the CD5 positive cells was membrane ADA positive. The percentage thymocytes expressing membrane ADCP (14 \pm 8 ) was significantly different $(\mathrm{p}<0.001)$ from the percentage membrane $A D C P$ positive PBL-T (47 \pm 10$)$ (Fig. 4). In 4 experiments in which isolated PBL-T were incubated with a lysate of human erythrocytes the percentage of anti-ADA positive viable cells increased from $19 \pm 7$ to $51 \pm 11$ whereas no difference in $\mathrm{ADCP}$ expression was found. The results of a representative experiment are shown in Fig. 5.

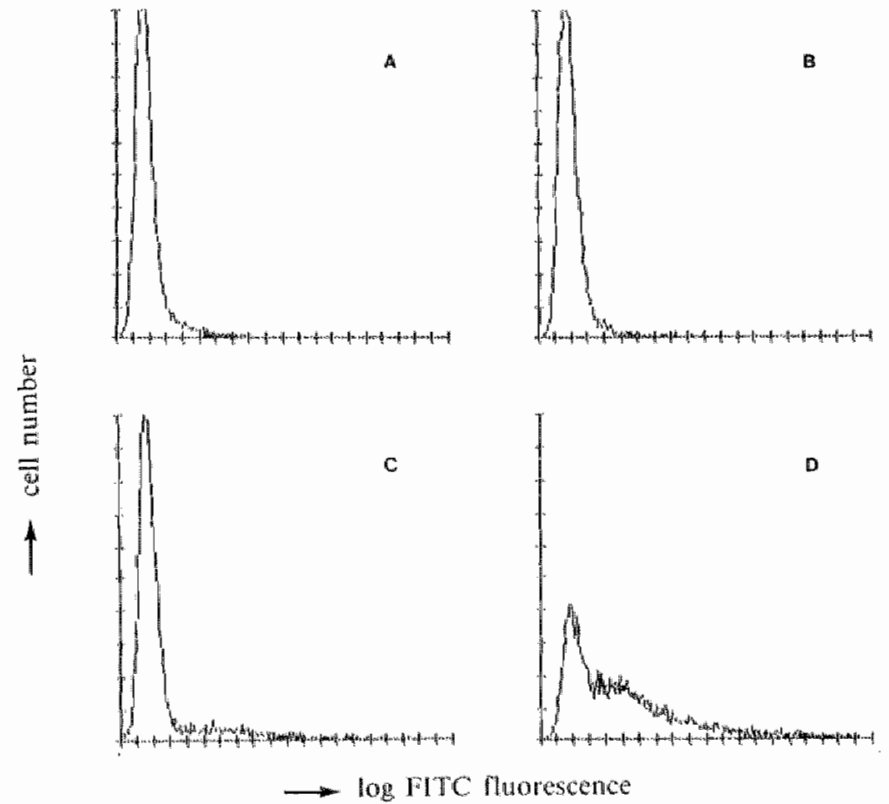

Fig. 5. Fluorescence histograms

A. PBL, T preincubated with PBS and incubated with NRS

B. PBL-T preincubated with a lysate of human erythrocytes and incubated with NRS

C. PBL-T preincubated with PBS and incubated with anti-ADA antiserum

D. PBL-T preincubated with a lysate of human erythrocytes and incubated with anti-ADA antisertim 


\subsection{Discussion}

The enzyme ADA is known to play a role in T-lymphocyte differentiation and ADA concentrations are reported to be subject to developmental control in cells of the T-lymphocyte lineage (25-27) and in epithelium of the gastrointestinal tract (27, 28). Protection of lymphoid cells from the toxic effects of elevated levels of adenosine and deoxyadenosine has been proposed as the main function of ADA in these cells (19). Although ADA occurs as a soluble protein, it has also been suggested to appear in a plasma membrane associated form in different mammalian cell types, displaying its enzymatic activity extracellularly $(17,18)$. It was postulated that membrane bound ADA protects the cells from toxic effects of adenosine and deoxyadenosine by extracellular metabolization $(11,29)$. As known from inherited ADA deficiency, human $\mathrm{T}$-lymphoid cells are extremely sensitive to adenosine and deoxyadenosine. Therefore, we investigated the capacity of these cells to degrade these substrates by extracellular metabolization. To this end we determined the occurrence of ADA on the outer surface of different subsets of human T-lymphoid cells. In man, ADA occurs in two major molecular forms: single or associated with the high molecular weight glycoprotein ADCP (3). In some human tissues ADCP was found predominantly associated with the plasma membrane (7-11), and could still bind ADA-S (7). Therefore, we also investigated the presence of ADCP in the membranes of human T-lymphoid cells and the ADA-S binding capacity of these cells. Cells with membrane bound ADA and cells with membrane bound ADCP were found in all investigated $T$-lymphoid cell populations but in varying numbers. At the population level the quantities of plasma membrane associated ADA and ADCP were not correlated. Whether or not these proteins occur on the same cells or on different cell populations remains to be determined by double labeling studies. However, the finding that the percentage of membrane ADA positive cells never exceeds the percentage of membrane bound ADCP positive cells together with the finding that after incubation with a lysate of human erythrocytes the percentage of membrane ADA positive T lymphocytes increases to that of the membrane ADCP positive cells suggests that membrane bound ADA is associated with membrane bound ADCP.

In human and rabbit tissues no unambiguous correlation between membrane bound ADCP and membrane bound ADA has been reported either $(8,16,30,31)$. These results and the finding that in erythrocytes ADA is partly attached to the plasma membrane (18), indicate that ADA in the plasma membrane is partly ADCP-free (ADA-S). Andy and Kornfeld (7) demonstrated that ADCP present in isolated membranes of fibroblasts has the capacity to bind ADA-S. It was suggested that membrane ADCP serves as a receptor for the recovery or removal of free ADA-S $(8,30)$. Recently Schrader et al. (30) suggested that in the rabbit intraveneously in fused ADA-S is cleared from the blood by binding to brushborder associated ADCP in the epithelial cells of the proximal convoluted tubules in the kidney. We found that intact PBL-T also have the capacity to bind ADA-S. As neither anti-ADA nor 
anti-ADCP antiserum inhibits the binding of $\mathrm{DDA}-\mathrm{S}$ to $\mathrm{ADCP}$ we were not able to investigate whether $\mathrm{ADA}$-S is anchored in the membranes by association to ADCP. $T$-helper/inducer cells significantly more often contained membrane associated ADCP than $\mathbb{T}$-cytotoxic/suppressor cells. The membrane ADCP content therefore appears to be a new quantitative difference between these cell populations.

It has been suggested that membrane bound ADCP aids in the extracellular detoxification of adenosine and deoxyadenosine by positioning ADA on the plasma membrane. In this respect it would be interesting to study the sensitivity for adenosine and deoxyadenosine of the ADCP positive and negative subpopulations. However, our observation that very few human thymocytes which are extremelly vulnerable to adenosine and deoxyadenosine toxicity, and have high ADA activity, show membrane ADCP expression does not support the role of ADCP in the extracellular detoxification of adenine nucleosides.

In summary, we found membrane bound ADCP more often in T-helper/inducer than in T-cytotoxic/suppressor cells, without a clear quantitative relationship with membrane bound ADA. The role of ADCP in the physiological function of ADA therefore remains unclear.

\subsection{References}

1. Giblett ER, Anderson JE, Cohen F, Pollara B, Meuwissen HJ (1972) Adenosine deaminase deficiency in two patients with severely impaired cellular innmunity. Lancet ii, 1067-1069.

2. Thompson LF, Seegmiller JE Adenosine deaminase deficiency and severe combined immunodefi. ciency diseatse. In: Advances in Enzymology, wol. 51 (Meister A, ed.), Academic Press, New York, 1980 , pp. $167-210$.

3. Daddona PE, Kelley WN (1980) Analysis of normal and mutant forms of human adenosine deaminase. A review. Mol. Cell Biochem. 29: 91-101.

4. Herbschleb-Voogt E, Pearson PL, Vossen JM, Meera Khan P (1981) Basic defect in the expression of adenosine deaminase in ADA-SCID disease investigated through the cells of an obligate heterozygote. Hum. Genet. 56:379-386.

5. Herbschleb-Voogt E, Ten Kate J, Meera Khan P (1983) Adenosine deaminase complexing protein: a transformation sensitive protein with potentials of a cancer marker. Anticancer Res. 3: 95-100.

6. Nishihara H, Ishikawa $S$, Shinkai $K$, Akedo H (1973) Multiple forms of human adenosine deaminase. 11. Isolation and properties of a conversion factor from human lung. Biochim. Biophys. Acta 302: $429-442$.

7. Andy RI, Kornfeld R (1982) The adenosine deaminase binding protein of human skin fibroblasts is located on the cell surface. J. Biol. Chem. 257: 7922-7925.

8. Schrader WP, Bryer P (1982) Characterization of an insoluble adenosine deaminase complexing protein from human kidney. Arch. Biochem. Biophys, 215: 107-115.

9. Schrader WP, West CA (1985) Adenosine deaminase complexing proteins are localized in exocrirue glands of the rabbit. J. Histocthem. Cytochem. 33:508-515. 
10. Ten Kate J, Wijen JT, Boldewijn J, Meera Khan P, Bosman FT (1985) Immunothistochombal localization of adenosine deamimase complexing protein in inesunal mueosa and in colorectal adenocarcinomas as a marker for tumour cell heterogeneity. Histochem. $1.17,23-31$.

11. Trota PP (1982) Identification of membrane associated adenosine deaminase binding proten from human placenta. Biochemistry $21: 4014 \times 4023$.

12. Agarwal RP, Parks RE jr (1975) A possible association berween the nucleoside transport system of human erythrocytes and adenosine deamirase. Biochem. Pharmac. 24: 547-550.

13. De Bruijn CHMM, Oei TL (1974) Purine metabolism in intact erythrocytes from controls and HoiPRT deficient indiwiduals. Adv. Exp. Med. Biol. 41A: 223-227.

14. Schrader I, Berne RM, Rubio F (1972) Upake and metabohism of adenosine by human eryllhowy ghosts. Am. J. Physioll. 223: 159-166.

15. Tritsch GL, Paolini NS, Bielat K (1985) Adenosine deamingse activily associated with phagocylic vacuoles. Histochemistry $82: 281-285$.

16. Varu den Weyden MB, Kelley WN (1976) Human adenosine deaminase: distribution and propyerties. J. Biol. Chem. $251: 5448-5456$.

17. Pfleger K, Niederau D, Volkmer I (1969) Ein Beitrag zum Wirkungsmechanismus von Dipyridamol: Hemmung der Adenosinaufnahme in Erythocyten durch Dipyridamol. Arch, Exp. Pathol. Pharmakol. 265: 118-130.

18. Turnheim K, Plank B, Kolassa $N$ (1978) Inhibition of adrnosime uptake in human erythrocyles by adenosine-5'-carboxamides, xylosyladenine, dipyridamole, hexobendine, and pmitrobenzylthioguanosine. Bilochem. Pharmac. 27: 2191-2197.

19. Fox IH, Kelley WN (1978) The role of adenosine and 2'-deoxyadenosine in mammalian calls. Anm. Rev. Biochem. 47; 655-686.

20. Roos D, Loos JA (1970) Changes in the carbohydrate metabolism of mitogenically stimulated lunman peripheral lymphocytes. I. Situmulation by phytohaenaggluninia, Biochim. Biophys. Acta 222: $565-582$.

21. Astaldi GCB, Astaldi A, Groenewoud M, Wijermans P, Schellekens PTA, Eijswoogel VP (1977) Effect of a human serum thymic factor on hydrocortisone-ireated thymocytes. Eur. I. Immunol. $7: 836-840$.

22. Herbschleb-Voogt E, Scholten JW, Meera Khan P (1983) Basic defect in the expression of adenosine deaminase in ADASCID disease. H. Deficiency of ADA CRM detected in heterozygote human-Chinese hamster cell hybrids. Hum. Genet. 63: 121-125.

23. Ten Kate J, Wijnen JT, wan der Goes EGM, Quade R, Grilloen G, Bosman FT, Mcera Khan P (1984) Quantitative changes in adenosine deaminase isozymes un human colorectal adenocarcinomas. Cancer Res. 44: $4688-4692$.

24. Schrader WP, Stacy AR (1977) Purification and subunil structure of adenosine dethmase from hillman kidney. I. Biol. Chem. 252:6409 6415.

25. Hirschthorn $\mathrm{R}$, Martinuik $F$, Rosen $\mathbb{E} S$ (1978) Adenosine deaminase activity in normal lissues and tissues from a child with severe combined immonodeficiency and adenosine deaminase deficiency. Clin. Immun. Immunopath. 9: $287-292$.

26. Kizaki H, Habu $\mathrm{S}$, Ohsaka F", Sakurada $\mathrm{T}$ (1983) Purine nucleoside metabolizing enzyme axtivities in mouse thymocytes at different stages of differentation and maturation. Cell. Imnunol. 82: $343-35 \%$.

27. Lee PC (1973) Developmental ahenges of adenosine deaminase, xanthine oxidase, and uncase in mouse tissues. Dev. Biol. 31: 227-233.

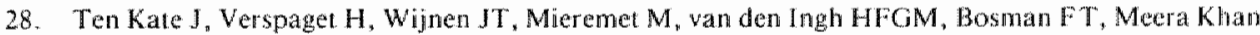
P. Maturation dependent changes in nucleoside phosphorylase, adenosine deaminase and is conoplexing protein in intestinal epithelial cells. In: Proc, 32 colloqutum Protides of the Biological Fluids (Peeters H, ed.), Pergamon Press, Oxford, 1985 pp. 339-342. 
29. Chechil BE, Baumal R, Sengupta $S$ (1983) Localization and identity of adenosine-deaminasepositive cells in tisuses of young rat and calf. Histochem. J. 15: 373-387.

30. Schrader WP, Harder CM, Schrader DK, West CA (1984) Metabolism of several molecular forms of adenosine deaminase intraveneously infused into the rabbit. Arch. Biochem. Biophys. 230: 158.167 .

31. Schrader WP, West CA, Stroninger NL (1987) Localization of adenosine deaminase and adenosine deaminase complexing protein in rabbit brain. J. Histochem. Cytochem. 35: $443-451$. 


\section{Chapter 6}

\section{Adenosine deaminase complexing protein (ADCP) immunoreactivity in adenocarcinomas*}

\subsection{Introduction}

The adenosine deaminase complexing protein (ADCP) is present in all human cells with the exception of erythrocytes. By quantitative biochemical and qualitative immunohistochemical studies we demonstrated high concentrations of this protein in the intestinal tract, kidney, prostate, secretory endometrium and mammary gland (1). ADCP has been regarded as a potentially interesting tumor associated antigen because in colorectal adenocarcinomas the quantity and localization were altered (2-7). We demonstrated that the expression of $A D C P$ in colorectal adenocarcinomas correlates with that of secretory component (7), of which the expression correlates with tumor stage and prognosis (8-10). Furthermore, in prostatic adenocarcinomas the pattern of ADCP immunoreactivity is associated with the presence of metastases (11). In colorectal and prostatic adenocarcinomas the cellular localization of ADCP might be used as a parameter for the assessment of the degree of differentiation of the tumor $(7,11)$.

These results prompted us to study ADCP expression by immunohistochemistry in gastrointestinal, renal, endometrial, mammary and ovarian neoplasms and metastases. Ovarian neoplasms were included because the tumor cells of mucinous cystic neoplasms of the ovary can show intestinal characteristics (12).

\subsection{Materials and Methods}

\subsubsection{Antibodies}

Two ADCP reactive monoclonal antibodies (clones 1071 and 1072) were obtained by immunizing mice subcutaneously with purified native human ADCP adsorbed to a nitrocellulose membrane (Schleicher and Schuell, Dassel, FRG). During 7 days prior to fusion the mice were boosted 5 times intraveneously with a lysate of human kidney cortex (13).

\footnotetext{
* Dinjens WNM, van der Linden EPM, Lenders MHJH, ten Kate J, Meera Khan P. Bosman FT. Submitted for publication.
} 
Specificity of the 2 monoclonal antibodies was demonstrated by immunoprecipitation followed by SDS-PAGE or starch gel electrophoresis as described previously (11). The well documented polyclonal anti-human ADCP antiserum was raised in a Chinchilla rabbit. The rabbit was immunized with $40 \mu \mathrm{g}$ of purified native human ADCP emulsified in Freund's complete adjuvant. Serum was collected after 3 booster injections with $40 \mu \mathrm{g}$ of ADCP emulsified in Freund's incomplete adjuvant. The specificity of the antiserum was tested by immunoprecipitation and SDS-PAGE (5).

\subsubsection{Tissue panel.}

Reactivity of the monoclonal antibodies with a panel of normal and neoplastic human tissues was investigated. Because the monoclonal antibodies did not show reactivity on sections of formalin fixed and paraffin embedded human tissues we used cryostat sections. We examined tissue specimens of at least 3 different individuals including normal kidney, prostate, mammary gland, endometrium, stomach and small and large intestine. The investigated neoplasms were 24 renal cell carcinomas, 5 primary breast adenocarcinomas and 2 lymph node metastases of breast adenocarcinomas, 23 endometrial adenocarcinomas, 15 gastric adenocarcinomas, 1 adenocarcinoma of the small intestine and its lymph node metastasis, 13 ovarian carcinomas and 7 ovarian adenomas, 1 omentum metastasis from an ovarium carcinoma, 16 colorectall adenocarcinomas, 2 liver, 2 lymph node and 1 skin metastases of colorectal adenocarcinomas and 4 colorectal adenomas. Staging of the renal cell carcinomas was performed according to Robson (14).

\subsubsection{Immunohistochemistry}

Cryostat sections $(4 \mu \mathrm{m})$ were air dried and fixed in periodate-lysine-paraformaldehycle (15) for $10 \mathrm{~min}$ at room temperature (RT). After rinsing in phosphate buffered saline (PBS) endogenous peroxidase activity was inhibited by treating the sections with a $0.5 \%(\mathrm{v} / \mathrm{v})$ solution of hydrogen peroxide in PBS for $30 \mathrm{~min}$ at RT. The procedure for the indirect immunoperoxidase technique was followed as described elsewhere (3). Prior to application of polyclonal antibodies the sections were preincubated with $20 \%(\mathrm{v} / \mathrm{v})$ normal goat serum to reduce non-specific binding. Ulimately peroxidase activity was visualized by using diaminobenzidine tetrahydrochloride (DAB, Serva, Heidelberg, FRG) as substrate. The sections were counterstained with hematoxylin. 


\subsection{Results}

\subsubsection{Reactivity in normal human tissues}

Table I summarizes the reactivity of the ADCP reactive antibodies on normal human tissues. In the kidney cortex immunoreactivity was confined to the brushborder region of the epithelial cells of the proximal convoluted tubules. In the prostate strong immunoreactivity was found in the apical membrane and apical cytoplasm of the glandular epithelial cells and in the secretory vesicles and fluid in the glandular lumen. In the mammary gland reactivity was found along the luminal pole of the epithelial cells of lobuli and ducts. Proliferative endometrium did not show reactivity with the investigated antibodies. However, in secretory endometrium immunoreactivity was found confined to the apical membranes of the secretory epithelial cells of most endometrial glands. In the stomach reactivity with monoclonal antibodies 1071 and 1072 was found associated with the apical membranes of the columnar cells lining the foveolae and gastric glands. The foveolar epithelial cells also showed diffuse cytoplasmic immunoreactivity (Fig. 1). In the stomach no immunoreactivity with the polyclonal antiserum was found. Strong immunoreactivity with all antibodies was observed in the small and large intestine corresponding with the brushborder region of the epithelial cells. The polyclonal antiserum did not react with goblet cells (Fig. 2) whereas both monoclonal antibodies showed diffuse cytoplasmic reactivity with goblet cells (Fig. 3) but with striking heterogeneity, ranging from negative to intense staining.

Table I Reactivity of ADCP reactive antibodies with normal human tissues

\begin{tabular}{lccc}
\hline Tissue & $\begin{array}{l}\text { Polyclonal } \\
\text { antiserum }\end{array}$ & 1071 & 1072 \\
\hline Kidney & + & + & + \\
Prostate & + & + & + \\
Breast & + & + & + \\
Endometrium & - & - & + \\
$\quad$ proliferative & + & + & + \\
$\quad$ Stomach & - & + & + \\
Small intestine & + & + & + \\
Large intestine & + & + & + \\
\hline
\end{tabular}

\subsubsection{Reactivity in neoplasms}

The reactivity of $\mathrm{ADCP}$ specific polyclonal and monoclonal antibodies with human neoplasms is shown in Table II. 


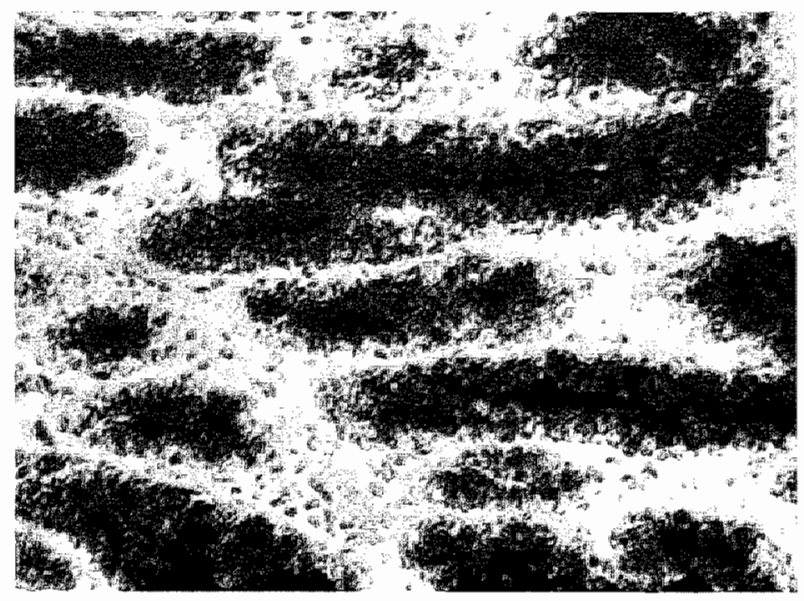

Fig. 1. Reactiwity of MoAb 1071 in gastric mucosa showing diffuse cytoplasmic and apical membrane associated staining of the columnar cells lining the foveolae (frozen section, im* munoperoxidase, $200 \times$ ).

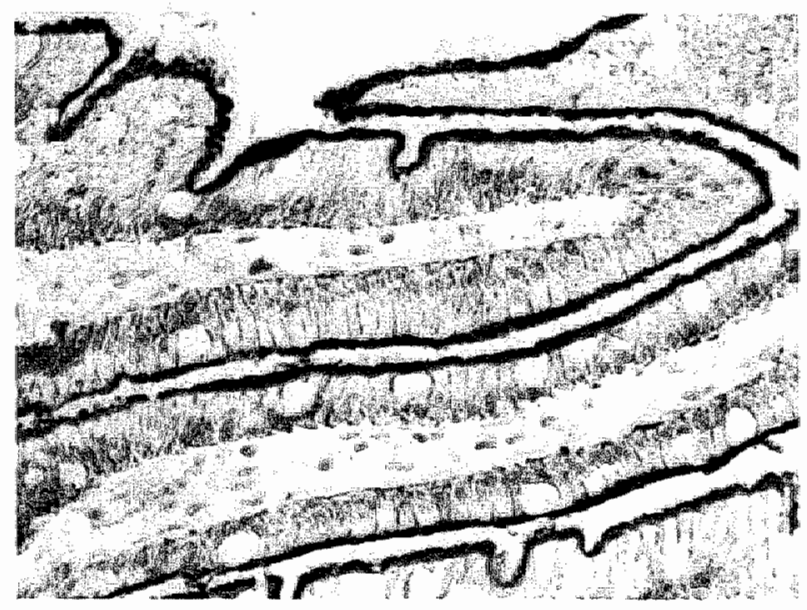

Fig. 2. Reactivity of polyclonal anti-ADCP antiserum in jejunal mucosa showing. brushborder associated staining (frozen section, immunoperoxidase, $180 \times)$.

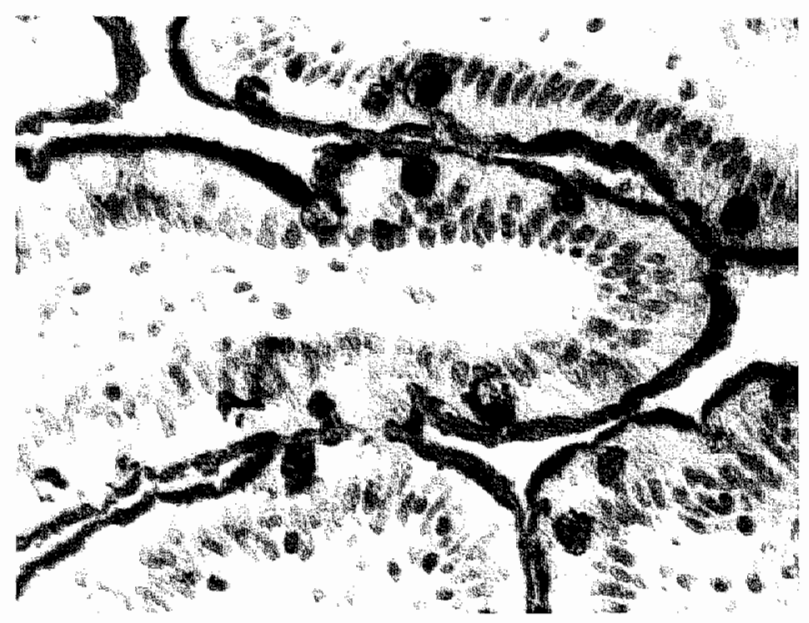

Fig. 3. Reactivity of MoAb 1071 in jejunal mucosa showing reactivity with mucin vacuoles in addition to brushborder associated reactivity (frozen section, immunoperoxidase, $300 \times$ ). 
Table II Reactivity of ADCP reactive antibodies with human neoplasms

\begin{tabular}{|c|c|c|c|c|}
\hline Neoplasm & $\mathbb{N}$ & $\begin{array}{l}\text { Polyclonal } \\
\text { antiserum }\end{array}$ & 1071 & 1072 \\
\hline Mammary adenocarcinomas & 5 & 2 & 2 & 2 \\
\hline lymph node metastases & 2 & 0 & 0 & 0 \\
\hline Endometrial adenocarcinomas & 23 & 13 & 13 & 13 \\
\hline \multicolumn{5}{|l|}{ Ovary: } \\
\hline clear cell carcinoma & 1 & 0 & 0 & 0 \\
\hline granullosa cell tumor & 1 & 0 & 0 & 0 \\
\hline serous cystadenocarcinomas & 9 & 1 & 1 & 1 \\
\hline serous cystadenoma & 1 & 1 & 1 & 1 \\
\hline omentum metastasis & 1 & 0 & 0 & 0 \\
\hline mucinous cystadenocarcinomas & 2 & 2 & 2 & 2 \\
\hline mucinous cystadenomas & 6 & 5 & 5 & 5 \\
\hline Gastric adenocarcinomas & 15 & 2 & 9 & 7 \\
\hline Small-intestinal adenocarcinoma & 1 & 1 & $\mathbb{\Perp}$ & 1 \\
\hline lymph node metastasis & 1 & 1 & 1 & 1 \\
\hline Colorectal adenocarcinomas & 16 & 10 & 11 & 12 \\
\hline lymph node metastases & 2 & 1 & 1 & 1 \\
\hline liver metastases & 2 & 1 & 1 & 1 \\
\hline skin metastasis & 1 & 0 & 1 & 1 \\
\hline Colorectall adenomas & 4 & 4 & 4 & 4 \\
\hline
\end{tabular}

1 Results are expressed as the number of positive specimens

$\mathbb{N}=$ Number of specimens

\section{Breast adenocarcinomas}

Two out of 5 investigated infiltrating ductal carcinomas focally showed weak diffuse cytoplasmic and apical reactivity with all tested antibodies, the other 3 were negative.

\section{Endometrial adenocarcinomas}

The polyclonal antibodies reacted with 13 of 23 investigated endometrial adenocarcinomas. With both monoclonal antibodies 13 tumors showed reactivity. Intercellular heterogeneity was observed in all neoplasms. Solid tumor masses were usually negative, glandular structures were often locally positive.

\section{Ovarian neoplasms}

All antibodies reacted weakly with only 1 of 9 serous cystadenocarcinomas in an apical pattern. A metastasis in the omentum of a negative tumor was also negative. The same reactivity pattern, but stronger, was observed in the single investigated serous 


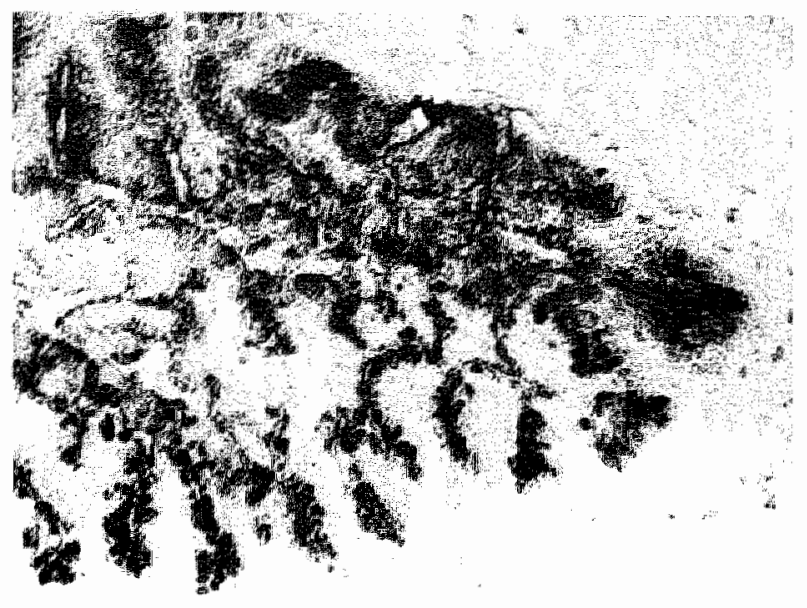

Fig. 4. Mucinous cystadenocarcinoma of the ovary stained with MoAb $107 \rrbracket$ showing apical mem. brane associated and mucin wacuole reactivity (frozen section, immunoperoxidase, $200 \times)$.

cystadenoma. The two mucinous cystadenocarcinomas both were positive with all antibodies. All antibodies reacted with 5 out of 6 mucinous cystadenomas. In the mucinous cystic neoplasms the reactivity was always focal and apical membrane associated with or without diffuse cytoplasmic reactivity. In addition, both monoclonal antibodies reacted with mucin vacuoles (Fig. 4). In two other ovarian neoplasms, a clear cell carcinoma and a granulosa cell tumor, no immunoreactivity was found.

\section{Gastric adenocarcinomas}

The polyclonal antiserum reacted with 2 of 15 gastric adenocarcinomas. Monoclonal antibody $107 \mathbb{1}$ reacted with 9 tumors and 1072 with 7 . The common patterns of reactivity, apical or diffuse cytoplasmic staining, local and single or in combinations were encountered. Five gastric tumors were classified as diffusely infiltrative adenocarcinomas. They all showed diffuse cytoplasmic reactivity with 1071 and 1072 .

\section{Adenocarcinoma of the small intestine}

One adenocarcinoma of the small intestine and its lymph node metastasis both showed apical staining in glandular structures with polyclonal antibodies and 1071 and 1072 . Solid tumor fields were negative.

\section{Colorectal neoplasms}

In 10 out of 16 colorectal adenocarcinomas reactivity of the polyclonal antibodies was observed, in 11 reactivity with monoclonal antibody 1071 and in 12 with 1072 . All 4 colorectal adenomas reacted with all applied antibodies. The reactivity was invariably local and in an apical, diffuse cytoplasmic, or granular cytoplasmic pattern. These patterns were also found in combinations. The polyclonal antibodies did 
not react with goblet cells whereas 1071 and 1072 showed diffuse cytoplasmic and mucin associated reactivity in this cell type. The 4 colorectal adenomas showed apical staining with the polyclonal antibodies. Staining with 1071 and 1072 furthermore showed diffuse cytoplasmic ( 2 cases) or granular cytoplasmic (2 cases) reactivity. One lymph node metastasis of an ADCP negative primary colorectal adenocarcinoma was negative for all the antibodies whereas another lymph node metastasis showed apical reactivity with all the antibodies. One liver metastasis of a colorectal adenocarcinoma reacted with an apical pattern. A skin metastasis of a colorectal adenocarcinoma showed focal apical staining with 1071 and 1072.

\section{Renal cell carcinomas}

Table III summarizes the reactivity of the ADCP specific polyclonal antibodies on renal cell carcinomas. The tumors were divided in non-metastatic stage I-III, stage I-III tumors that developed a metastasis and stage IV tumors. Four non-metastatic stage I-III tumors exclusively showed membrane associated reactivity (Fig. 5) whereas 6 stage I-III tumors showed in addition focally diffuse cytoplasmic staining (Fig. 6). All 4 of the stage I-III tumors that developed a metastasis focally showed diffuse cytoplasmic and membrane associated reactivity. From 10 stage IV tumors 5 were completely negative, 1 exclusively showed diffuse cytoplasmic staining and 4 reacted with the antiserum in a focal pattern, diffuse cytoplasmic as well as membrane associated.

Table III Reactivity of ADCP specific polyclonal antibodies with renal cell carcinoma'

\begin{tabular}{llll}
\hline \multirow{2}{*}{ Pattern } & \multicolumn{3}{c}{ Stage } \\
\cline { 2 - 3 } & I-III & I-III & IV \\
\hline Exclusively membranous & 4 & 0 & 0 \\
Focal membranous and cytoplasmic & 6 & 4 & 4 \\
Exclusively cytoplasmic & 0 & 0 & 1 \\
Negative & 0 & 0 & 5 \\
\hline
\end{tabular}

- Results are expressed as the number of positive specimens

2 Stage 1-11l tumors that developed a metastasis

\subsection{Discussion}

The reactivity patterns of the 2 monoclonal antibodies on normal human tissues largely matched the pattern observed with the polyclonal antiserum. Several differences, however, were observed. Monoclonal antibodies 1071 and 1072 did react with 

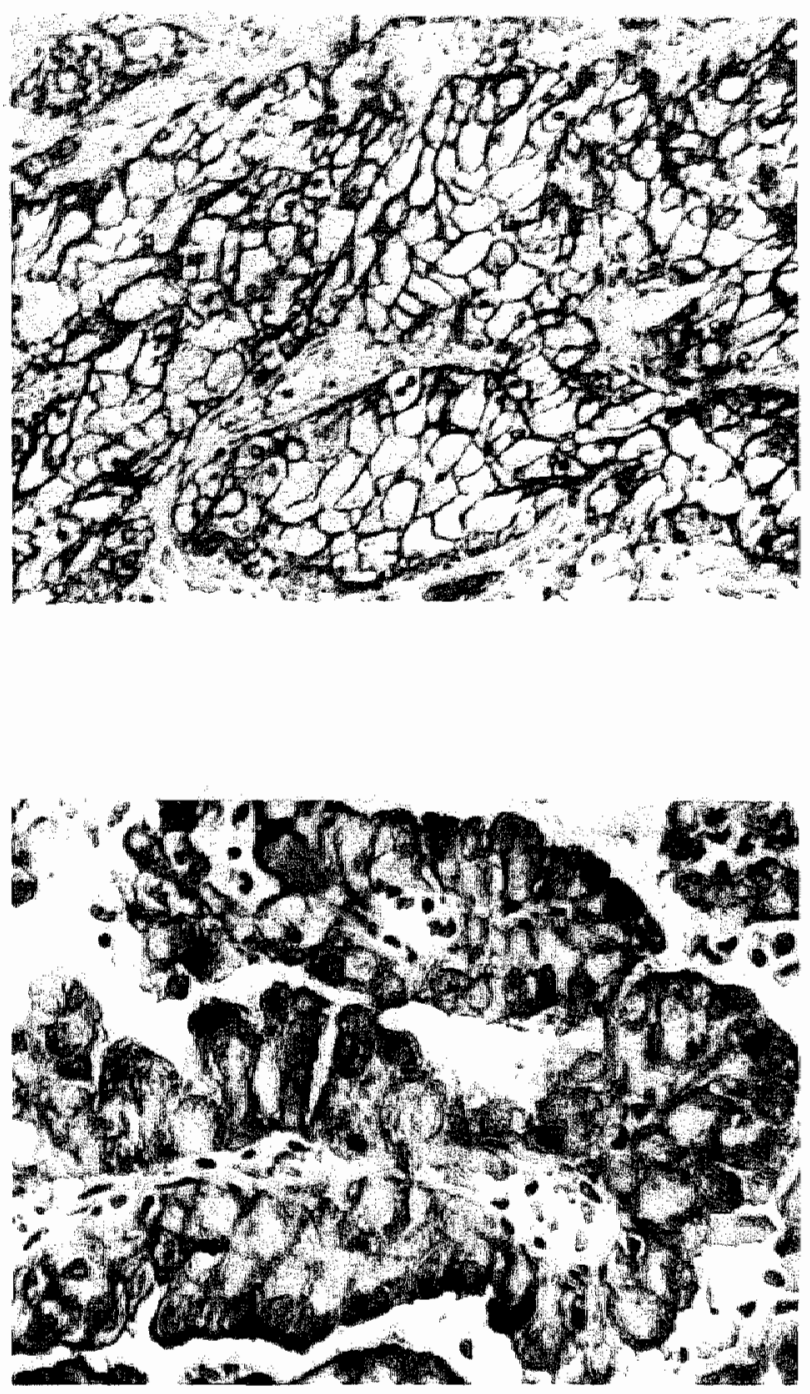

Fig. 5. Renall cell carcinoma stained with polyclonal antiADCP antisenum showing membrane associated reactivity (frozen section, immunoperoxidase, $200 \times$ ).
Fig. 6. Renal cell carcinoma stained with polyclonal antiADCP antiserum showing membrane associated and cytoplasmic reactivity (frozen section, immunoperoxidase, $400 \times$ ).

the epithelial cells of the gastric foveolae and glands, which did not stain with polyclonal antiserum. Both monoclonal antibodies stained goblet cells and mucin vacuoles in the intestinal tract, which did not stain with the polyclonal antiserum. The additional reactivity of the monoclonal antibodies was retained when the antibodies were dilluted in $2 \mathrm{M} \mathrm{NaCl}, 2 \%(\mathrm{v} / \mathrm{v})$ Tween 20 or both and therefore is probably not a result of non-specific interactions. These findings question the specificity of the monoclonal antibodies or the sensitivity of the polyclonal antiserum. We demonstrated previously that both monoclonal antibodies react with purified ADA- 
free ADCP from human kidney cortex and with ADCP in lysates of human kidney cortex and cultured human skin fibroblasts (13). These results suggest that different molecular forms of ADCP exist, all present in the kidney cortex but not all recognized by the polyclonal antiserum. However, the polyclonal antiserum as well as the monoclonal antibodies were generated against ADCP purified from kidney cortex. None of the described ADA isozymic forms shows a tissue distribution comparable to the reactivity of the monoclonal antibodies $(16,17)$. The observed differences in reactivity may be related to the species in which the antibodies were generated (rabbit versus mouse) or may be a result of the different preparations chosen for ADCP immunization, soluble for the generation of polyclonal antiserum versus solid phase adsorbed for the generation of monoclonal antibodies. Another possibility is that the monoclonal antibodies recognize epitopes on the ADCP molecule which are also present on other molecules (e.g. mucins) but which are not recognized by the polyclonal antiserum. More extensive tests for reactivity of the monoclonal antibodies are required to resolve this issue. As yet we regard these monoclonal antibodies as ADCP reactive and they can not be considered as ADCP specific.

In all the investigated normal human tissues the immunoreactivity patterns demonstrated epitheliall cell polarity. ADCP reactivity localized predominantly in exocrine glands and absorptive epithelia especially at the secretory or absorptive apex of the epithelial cells $(1,18)$. This finding led to the suggestion that ADCP is a secretion and/or absorption associated protein. ADCP expression in endometrial glands exclusively during the secretory phase and confined to the secretory edge of the epithellial cells points to a relationship between the presence of ADCP and the secretory process. However, the occurrence of $\mathrm{ADCP}$ in intestinal and proximal tubular epithelial cells and cultured fibroblasts illustrates that ADCP is not an exclusively secretory protein.

In neoplasms immunoreactivity with the $A D C P$ reactive antibodies could roughly be discriminated into apical membrane associated, diffuse cytoplasmic, granular cytoplasmic and negative. These patterns often appeared focally in the tumor and are comparable to the reactivity patterns described for the polyclonal antiserum in colorectal and prostatic adenocarcinomas $(3,7,11)$. The presence or absence of ADCP in tumors might be associated with type and degree of differentiation. The differences in ADCP expression patterns observed in tumors, compared to their normal tissue counterparts, can be due to differences between normal and neoplastic cells in posttranslational mechanisms in which the ADCP molecule is involved. These mechanisms include posttranslational modification of the protein as described for e.g. spectrin (19), villin (20), sucrase-isomaltase (21) and mucins (22, 23) or modified catabolism as described e.g. for spectrin (20) and sucrase-isomaltase (21). The possibility that ADCP expression might be correlated with tumor behavior was studied in 24 well staged renal cell carcinomas. Staging is a reflection of the tumor spread, including degree of invasion and presence or absence of metastases and as such is an indication of the biological behavior of the tumor. All 4 tumors with membrane ADCP expression, as in the normal kidney, were non-metastatic 
stage 1-III tumors and all 5 ADCP negative tumors were stage IV tumors. These findings resemble the observations in prostatic adenocarcinomas, where strong membrane associated staining occurs in non-metastastic tumors. These results justify further exploration of ADCP expression as an indication for tumor progression in selected tumor types.

The use of ADCP expression in a neoplasm for histogenetic tumor classification or for determination of the primary in metastases of unknown origin is limited because ADCP occurs in endodermal (intestinal tract), ectodermal (endometrium, breast) and mesodermal (kidney) tissues. However, within one organ, ADCP expression may be used as a parameter to determine the cell of origin or the degree of differentiation. This is illustrated in the kidney where the expression of ADCP in renall cell carcinomas supports the view that these tumors originate from proximal tubular epithelial cells. Along the same line, ADCP expression in mucinous cystadenocarcinomas and gastric adenocarcinomas in a pattern comparable to that in intestinal epithelium fits the hypothesis that in these neoplasms the epithelium shows intestinal differentiation $(12,24)$.

In a number of endometrial and 1 adenocarcinoma of the small intestine reactivity patterns were found in histological well differentiated areas, comparable to the patterns found in the normal tissue counterparts. Also in colorectal adenomas and mucinous cystadenomas of the ovary normal patterns of reactivity were observed. These results favor the suggestion that a reactivity pattern in a tumor, resembling the pattern in normal tissue, is indicative for the presence of highly differentiated cells in the neoplasm. Comparable to what was reported in colorectal adenocarcinomas (7) we found that the reactivity of the polyclonal antiserum correlated with the presence of secretory component in endometrial, intestinal, mammary and ovarian neoplasms (data not shown). In colorectal tumors expression of secretory component appeared to be of prognostic significance (8-10) but at present there is no evidence that the pattern of ADCP expression correlates with prognosis. The occurrence of metastases in both ADCP positive and negative primary tumors questions the value of ADCP as a prognostic indicator. Studies concerning the relationship between ADCP expression and biological behavior of neoplasms are severely hampered by the inability of our antibodies to react with routinely processed tissue specimens.

In summary, the reactivity patterns of the $\mathrm{ADCP}$ reactive monoclonal antibodies on normal and neoplastic human tissues largely matches the pattern observed with the polyclonal antiserum. In normall tissues ADCP expression demonstrates epithelial cell polarity. The deviation of this expression pattern in neoplasms can be an indication for loss of polarity and as such for absence of or incomplete differentiation. Our results suggest that the expression of ADCP might be a useful parameter in the assessment of the histogenesis and type and degree of differentiation of tumors. Future studies should focus on the relationship between the regulation of the ADCP expression and biologicall behavior of the tumor. 


\subsection{References}

1. Dinjens WNM, ten Kate J, van der Linden EPM, Wijnen UT, Meera Khan P, Bosman FT. Distribution of adenosine deaminase complexing protein (ADCP) in human tissues. Submitted for publication (This thesis Chapter 4).

2. Trotta PP, Balis ME (1978) Characterization of adenosine deaminase from normal colon and colon tumors. Evidence for tumor specific variants. Biochemistry 17:270-278.

3. Ten Kate J, Wijnen JT, Boldewijn J, Meera Khan P, Bosman FT (1985) Imunnohistochemical localization of adenosine deaminase complexing protein (ADCP) in intestinal mucosa and in colorectal adenocarcinoma as a marker for tumour cell heterogeneity. Histochem. $\mathfrak{1}$. 17: 23-31.

4. Ten Kate J, Wijnen JT, Herbschleb-Voogt E, Griffoen G, Bosman ET, Meera Khan P. Specitic isozyme profiles of adenosine deaminase in colorectal adenocarcinoma. In: Selected topies in clinical enzymology (Goldberg D and Werner M, Eds.), Walter de Gruyter, New York, 1983, pp. 11.27.

5. Tern Kate J, Wijnen JT, van der Goes RGM, Quadt $R$, Griffioen $G$, Bosman $F T$, Meera Khan $P$ (1984) Quantitative changes in adenosine deaminase isozymes in thuman colorectal adenocatinomas. Cancer Res. 44: 4688-4692.

6. Ten Kate J, Beukers J, van der Goes RGM, Wijnen JT, Romijn J, Griffioen G, Bosman FT, Meera $K$ han $P$. Adenosine deaminase complexing protein (ADCP): a transformation sensitive marker and a possible tool in immunodiagnostics of solid tumors. In: Proc. 1 colloquium Protides Biol. Filuids (Peeters H, Ed.), Pergamon Press, Oxford, 1984, pp. 355-358.

7. Ten Kace J, van den Ingh HFGM, Meera Khan P, Bosman FT (1986) Adenosine deaminase complexing protein $(A D C P)$ immunoreactiity in colorectal carcinoma. Int. J. Cancer 37: 479-485.

8. Arends JW, Wiggers T, Thijs CT, Verstijnen C, Swaen GJV, Bosman FT (4984) The value of secretory component (SC) immunoreactivity in diagnosis and prognosis of colorectal carcinomas. Am. J. Clin. Pathol. 82: 267-274.

9. Rognum TO, Brandizaeg P, Orjasaeter H, Elgjo K, Hognestad J (1980) Immunohistochemical study of secretory component, secretory $\operatorname{lgA}$ and carcinoembryonic antigen in large bowel carcinomas. Pathol. Res. Pract. 170: 126-145.

10. Rognum TO, Elgjo K, Brandtzaeg $\mathbb{P}$, Orjasaeter H, Bergen A (1982). Plasma carcinoembryonic antigen concentrations and immunohistochemical patterns of epithelial marker antigens in patients with large bowel carcinoma. J. Clin. Pathol. 35: 922-933.

11. Dinjens WNM, ten Kate J, Kirch JAJM, wan der Linden EPM, Tanke H, Jonas U, van den Ingh HFGM, Meera Khan P, Bosman FT. ADCP expression and metastatic potential in prostatic adenocarcinomas, Submitted for publication. (This thesis Chapter 7).

12. Louwerens JK, Schaberg A, Bosman F T (1983) Neuroendocrine cells in cystic mucinous utumours of the ovary. Histopathology 7:389-398.

13. Dinjens WNM, van der Linden EPM, Signet CM, Wijner UT, P. Meera Khan, ten Kate J, Bosman FT. Solid phase adsorption of antigens for efficient production of antibodies reactive with native and fixed tissue antigens. Submitted for publication (This thexis Chapter 2).

14. Robson CJ (1963) Radical nephrectomy for renal cell carcinoma. J. Urol. 89: 37-44.

15. McLean IW, Nakane PK (1974) Pertodate-lysine-paraformaldehyde fixative. A new fixative for immunoelectronmicroscopy. J. Histochem. Cytochem. 22: 1077.

16. Spencer $N$, Hopkinson DA, Harris $H$ (1968) Adenosine deaninase polymorphism in man. Am. Human Genet. 23: 9-14.

17. Edwards YH, Hopkinson DA, Harris H (1971) Adenosine deaninase isozymes in human I íssuds. Ann. Human Genet. 35: 207-219.

18. Schrader WP, West CA (1985) Adenosine deaminase complexing proteins are localized in exocrine glands of the rabbit. J. Histochem. Cytochem. 33: 508-514. 
19. Woods CM, Lazarides $\mathrm{E}$ (1985) Degradation of unassembled alpha and beta-spectrin in degradation. Cell $40: 959-969$.

20. Dubouet $\mathbb{B}_{\text {, Robine }} \mathrm{S}$, Huet $\mathrm{C}$, Sahuquillo-Merino $\mathrm{C}$, Blair $\mathbb{L}$, Coudrier $\mathrm{E}$, Louvard D (1987) Changes in villin synthesis and subcellular distribution during intestinal differentiation of HT29-18 clones. J. Cell Biol. 105: 359-369.

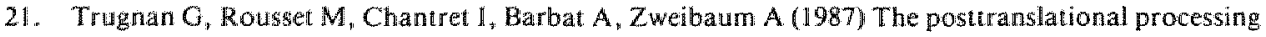
of sucrase-isomaltase in HT-29 cells is a function of their state of enterocytic differentiation. 1 . Cell Biol. 104: 1199-1205.

22. Boland CR, Montgomery CK, Kim YS (1982) Alterations in human colonic mucin occurring with cetlular differentiation and malignant transformation. Proc. Natl. Acad. Sci. USA 79: 2051-2055.

23. Verstijnen CPHJ. Tissue distribution of mucin reactive monoclonal antibodies in normall and neoplastic human tissue. Academic thesis, University of Limburg, 1987.

24. Laurến P (1965) The two histollogical main types of gastric carcinoma: diffuse and so called intestinal type carcinoma. Acta Pathol. Microbiol. Scand. 64: 31-49. 


\section{Chapter 7}

\section{ADCP expression and metastatic potential in prostatic adenocarcinomas*}

\subsection{Introduction}

In the human body the highest quantities of the adenosine deaminase complexing protein (ADCP) are present in the prostate, as determined by radioimmunoassay of tissue extracts (1). ADCP has been claimed to be a transformation sensitive protein in wiew of the finding that ADCP expression is markedly decreased or completely absent in the cytosol of some in vitro transformed human skin fibroblasts and human cancer derived cell lines (2-5). An immunohistochemical survey of 91 human primary colorectal aclenocarcinomas revealed markedly heterogeneous ADCP expression. Diffuse and granular cytoplasmic as well as membrane bound immunoreactivity occurred (6). Membrane associated ADCP immunoreactivity was found more frequently in well differentiated colorectal adenocarcinomas compared to undifferentiated tumors. In these adenocarcinomas the expression of ADCP appeared to be correlated with that of the secretory component, which thas been proven to be of prognostic significance. These findings suggested that the expression of ADCP in colorectal adenocarcinomas might also have prognostic significance. Against this background we investigated ADCP expression in 30 prostatic adenocarcinomas by immunohistochemistry. The observed ADCP expression patterns were correlated with the grade of the tumors. The ADCP expression patterns were also investigated in 7 human prostatic tumor cell lines grown as xenografts in athymic nude mice.

\subsection{Materials and Methods}

Raising, testing and specificity of the applied rabbit anti-human ADCP antiserum have been described previously (7). By radioimmunoprecipitation testing the antiserum appeared to detect two monomeric ADCP units of 94 and $109 \mathrm{kD}$. Our antiADCP antiserum did not detect ADCP in sections of routinely formalin fixed and paraffin embedded tissues. Therefore all prostatic adenocarcinoma specimens, obtained at biopsies or from transurethal resections, where fixed in periodate-lysine-

* Dinjens WWM, ten Kate J, Kirch JAJM, van der Linden EPM, Tanke H, Jonas U, van den Ingh HEM, Meera Khan P, Bosman FT. Submitied for publication. 
paraformaldehyde (PLP) (8) and embedded in paraffin following routine procedures. On $4 \mu \mathrm{m}$ sections the procedure for the indirect immunoperoxidase technique was followed as described by ten Kate et al. (6). In short, after deparaffinization and rehydration of paraffin sections they were washed in phosphate buffered saline (PBS). Endogenous peroxidase activity was inhibited by treating the sections with a $0.5 \%(\mathrm{v} / \mathrm{v})$ solution of hydrogen peroxide in methanol for $30 \mathrm{~min}$ at room temperature (RT). To prevent nonspecific binding the sections were incubated $(10 \mathrm{~min}$, RT) with $20 \%(\mathrm{v} / \mathrm{v})$ normal goat serum. Thereafter the anti-ADCP antiserum and goat anti-rabbit Ig peroxidase conjugate (Nordic, Tilburg, The Netherlands) were applied 2 and $1 \mathrm{~h}$ respectively at RT. Between each incubation sections were rinsed ( $3 \times 5$ min) in PBS. All antiserum dilutions were prepared with PBS containing $10 \%$ $(w / v)$ bovine serum albumin (Sigma, St. Louis MO, USA). Peroxidase activity was visualized with $0.05 \%(\mathrm{w} / \mathrm{v})$ diaminobenzidine tetrahydrochloride (DAB, Serva, Heidelberg, FRG) and $0.01 \%$ (w/v) hydrogen peroxide in Tris-HCl buffer ( $\mathrm{pH} 7.6)$ and the sections were counterstained with hematoxylin. Specificity of the immunolocalization was assessed by applying normal rabbit serum on parallel sections as negative control, and by using sections of human renal cortex, with a well documented ADCP immunoreactivity pattern, as positive control. On sections stained with hematoxylin and eosin the histological grade of the tumors was assessed independently by 2 pathologists, based on architectural and cyto-nuclear characteristics. The tumors were classified as well, moderately to well, moderately to poorly and poorly differentiated. The presence of metastases was determined by bone scan. Suspicious "hot spots" were re-investigated by directed X-ray. From patients with "hot spots" serum alkaline phosphatase, prostatic acid phosphatase and total acid phosphatase actiwitities were determined. Balb/c nude mouse xenografts of 7 different human prostatic tumors were a generous gift of Dr. G.J. van Steenbrugge, Department of Urology, Erasmus University, Rotterdam, The Netherlands. Characteristics of these cell lines are listed in Table II (compilation from ref. 9, with permission). ADCP specific immunohistochemistry of these xenografts was applied on cryostat sections, post-fixed in PLP (10 min, RT), following the procedure described for paraffin sections.

\subsection{Results}

In Fig. 1 the pattern of immunoreactivity in the normal human prostate is shown. The staining appeared to be confined to the apical membrane and apical cytoplasm of the secretory glandular cells. Also secretory vesicles and the contents of tubular lumina showed strong ADCP immunoreactivity. Flattened glandular epithelial cells, presumably inactive, showed no or only weak ADCP immunoreactivity. Myoepithelium also was negative.

In 30 prostatic adenocarcinomas we observed four distinct ADCP expression patterns: diffuse cytoplasmic (Fig. 2), strong membranous (Fig. 3), mixed cytoplasmic 
A

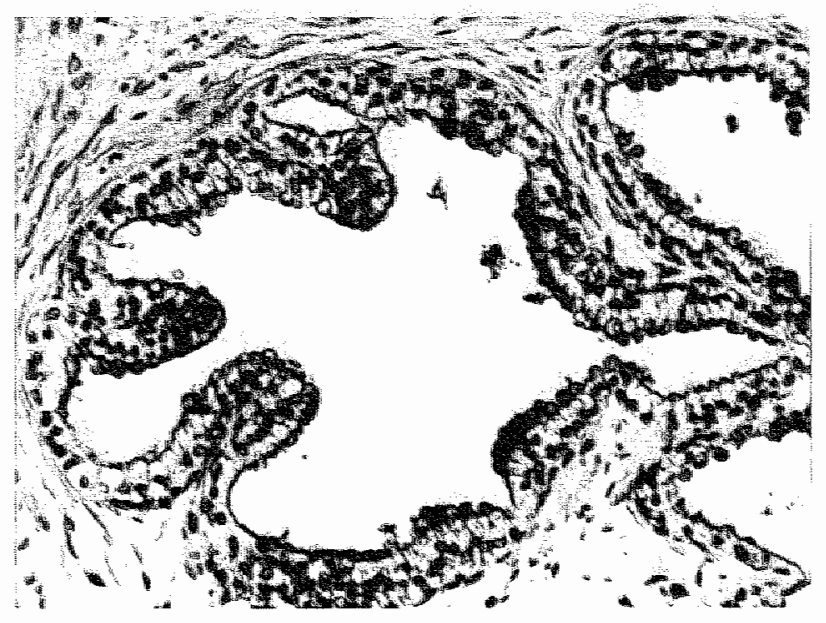

Fig. $1 \mathrm{~A}$ and B. ADCP immunoreativity in PLP fixed normal prostatic tissue. Note the staining of the apical membrane and apical. cytoplasm of the glandular epithelial cells and of secretory wesicles (immunoperoxidase, A: $200 \times$, B: $550 \times$ ).

B

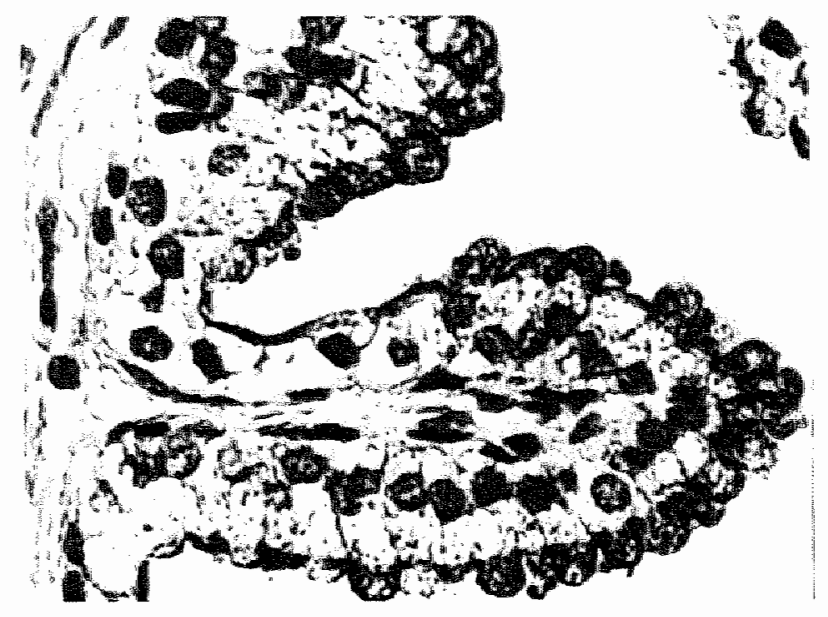

Fig. 2. ADCP im-

munoreativity in PLP fixed prostatic adenocarcinoma tissue. Note diffuse cytoplasmic staining (immunoperoxidase, $400 \times$ ).

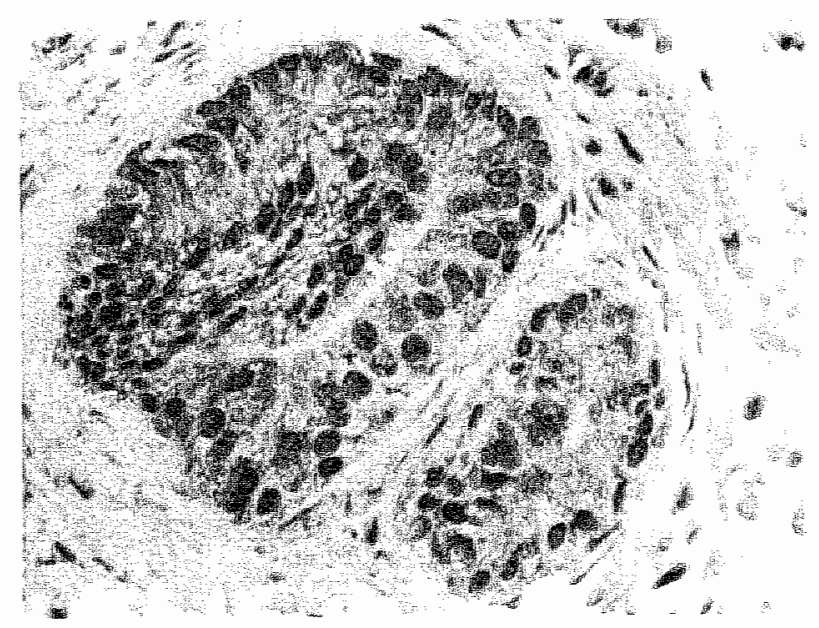



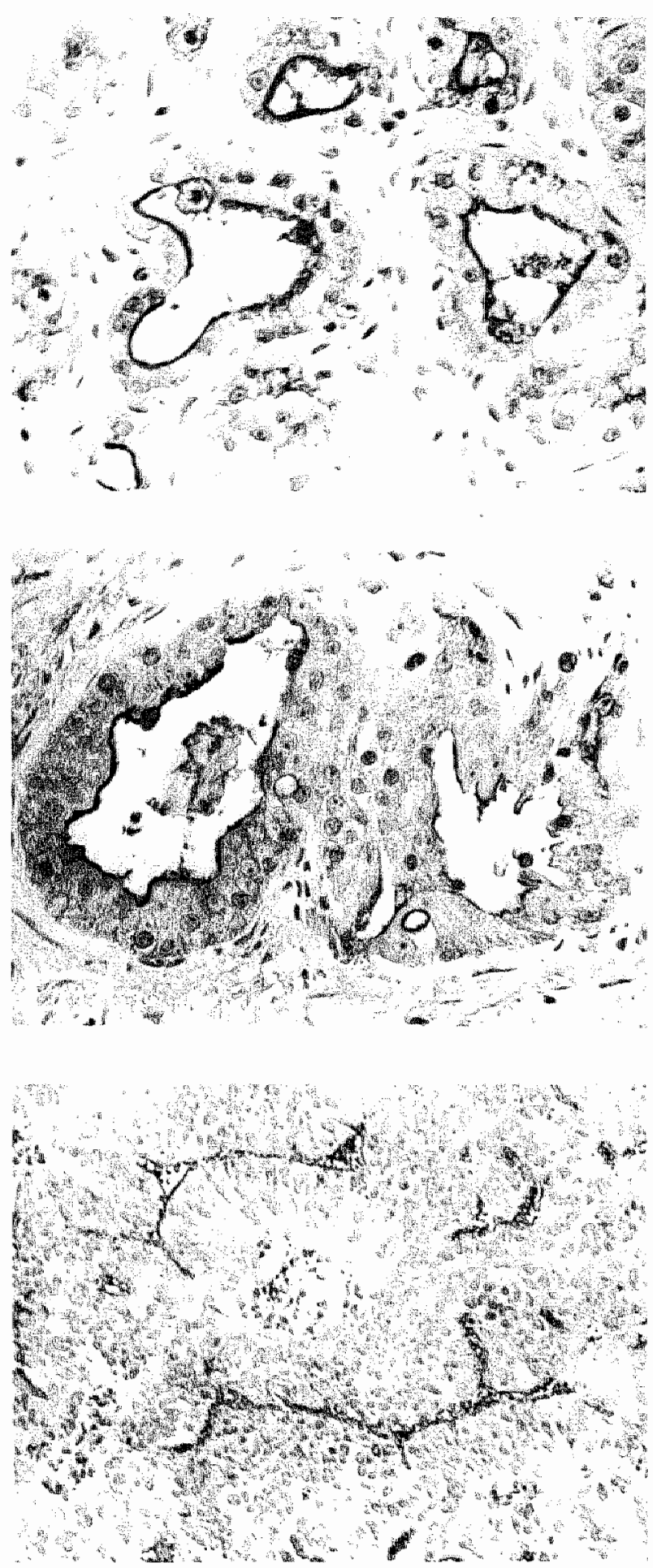

Fig. 3. ADCP immunoreactivity in PLP fixed prostatic adenocarcinoma tissue. Note strong apical membrane associated staining (immunoperoxidase, $400 \times$ ).

Fig. 4. ADCP immunoreactivity in PLP fixed prostatic adenocarcinoma tissue. Note the mixed cytoplasmic and membranous staining (immunoperoxidase, $400 \times$ ).

Fig. 5. ADCP immunoreactivity in PC-EW cells, xenografted in a nucle mouse. Note the membrane associated expression of ADCP (frozen section, immunoperoxidase, $200 \times$ ). 
Table 1 ADCP immunoreactivity patterns in 30 prostatic adenocarcinomas

\begin{tabular}{|c|c|c|c|c|}
\hline \multirow{2}{*}{ Patient } & \multirow{2}{*}{$\begin{array}{l}\text { Grade of } \\
\text { differentiation }\end{array}$} & \multicolumn{2}{|c|}{$\mathrm{ADCP}$ inmunoreactivity } & \multirow{2}{*}{ Metastases } \\
\hline & & Membranous & Cytoplasmic & \\
\hline 1 & W & ++ & - & $a$ \\
\hline 2 & $\mathrm{M}$ & ++ & - & a \\
\hline 3 & M & ++ & - & $\mathrm{a}$ \\
\hline 4 & $\mathrm{M}$ & ++ & - & a \\
\hline 5 & $\mathrm{M} / \mathrm{W}$ & +4 & - & a \\
\hline 6 & $\mathrm{~W}$ & $+t$ & - & a \\
\hline 7 & $\mathrm{M} / \mathrm{W}$ & $+t$ & - & a \\
\hline 8 & W & ++ & - & a \\
\hline 9 & W & $t+$ & - & a \\
\hline 10 & W & $t+$ & - & a \\
\hline $\mathbb{1 1}$ & M & + & - & $a$ \\
\hline $\mathbb{1 1}$ & M & + & ++ & $a$ \\
\hline $\mathbb{1} 3$ & $\mathrm{M}$ & + & $+t$ & $p^{\circ}$ \\
\hline 14 & M & - & $+t$ & $p^{*}$ \\
\hline 15 & $\mathrm{M}$ & - & $+t$ & $p^{* 0}$ \\
\hline 16 & M & - & $+t$ & $p^{*}$ \\
\hline 17 & M & - & $t+$ & $p^{*}$ \\
\hline 18 & M & - & ++ & $p^{45}$ \\
\hline 19 & $\mathbf{P}$ & $\cdots$ & $t+$ & $p^{\text {th }}$ \\
\hline 20 & $\mathrm{P}$ & - & ++ & $p^{\circ}$ \\
\hline 21 & M & - & $+t$ & $\mathrm{a}$ \\
\hline 22 & M & - & ++ & a \\
\hline 23 & M & - & $+t$ & $\mathrm{a}$ \\
\hline 24 & $\mathrm{M}$ & - & $+t$ & a \\
\hline 25 & $\mathrm{P} / \mathrm{M}$ & - & $+t$ & $\mathrm{a}$ \\
\hline 26 & $\mathrm{P} / \mathrm{M}$ & - & - & $\mathrm{px}$ \\
\hline 27 & $\mathrm{M}$ & - & - & $p^{*}$ \\
\hline 28 & $\mathrm{M}$ & - & - & $p^{\circ}$ \\
\hline 29 & $\mathrm{M}$ & - & - & $p^{*}$ \\
\hline 30 & $\mathrm{P} / \mathrm{M}$ & - & $-\infty$ & $\mathrm{a}$ \\
\hline
\end{tabular}

${ }^{\mathrm{W}} \mathrm{W}=$ Well differentiated; $\mathrm{M}=$ Moderately differentiated; $\mathrm{P}=$ Poorly differentiated; $=$ no; $+=$ weak $++=$ strong immunoreactivity; $a=$ absent; $p=$ present; Bone metastasis; "Lymph node metastasis; $x$ Lymph node, bone and lung metastases.

and membranous (Fig. 4) and no ADCP expression. Only very limited intercellular theterogeneity was observed but this might be due to the fact that most investigated specimens were small needle biopsies. As shown in Table I the 7 well or moderately to well differentiated tumors all showed exclusively membrane associated ADCP expression. In none of these patients metastases were observed. In contrast, in 5 tumors graded as poorly or poorly to moderately differentiated no membrane ADCP reactivity was found and 3 showed diffuse cytoplasmic ADCP expression. Of these 5 patients 3 appeared to have developed metastases. Of the 18 moderately 
differentiated tumors 3 were found to express exclusively membrane associated ADCP, 2 showed weak membrane associated and strong cytoplasmic staining, 9 showed exclusively diffuse cytoplasmic staining and in 3 specimens no ADCP staining could be observed. In none of the primary tumors of the 12 patients with metastases strong membrane associated ADCP expression was observed.

The results of $A D C P$ immunohistochemistry on prostatic adenocarcinoma cell line xenografts is shown in Table II. The 2 moderately differentiated xenografts showed apical membrane associated ADCP expression (Fig. 5), whereas the 5 poorly differentiated xenografts were all negative for $\mathrm{ADCP}$.

Table I』 ADCP inmunoreactivily in xenografts of human prostatic carcinomas

\begin{tabular}{|c|c|c|c|c|}
\hline Tumor & References & Origin & $\begin{array}{l}\text { Xenograft } \\
\text { grade of } \\
\text { differentiation }\end{array}$ & $\begin{array}{l}\text { ADCP } \\
\text { expression } \\
\text { pattern }\end{array}$ \\
\hline $\mathrm{PC}-82$ & (10) & primary tumor & moderately & $\begin{array}{l}\text { apical } \\
\text { membranous }\end{array}$ \\
\hline PC-EW & (111) & metastasis (1.n.) & moderately & $\begin{array}{l}\text { apical } \\
\text { membranous }\end{array}$ \\
\hline$P C-3$ & $(12)$ & $\begin{array}{l}\text { metastasis } \\
\text { (bone) }\end{array}$ & poorly & - \\
\hline $\begin{array}{l}\mathrm{PC}-93 \\
\mathrm{PC}-133\end{array}$ & $\begin{array}{l}(13) \\
(9)\end{array}$ & $\begin{array}{l}\text { primary tumor } \\
\text { metastasis }\end{array}$ & poorly & - \\
\hline & & (bone) & poorly & - \\
\hline PC. 135 & $(9)$ & primary tumor & poorly & - \\
\hline LNCaP & (14) & metastasis (1.n. & poorly & - \\
\hline
\end{tabular}

${ }^{1}$ l.n. = lymph node; - = no expression.

\subsection{Discussion}

In a study of a rather limited number of cases Trotta and Balis (15) claimed that in cancers of kidney and colon decreased $\mathrm{ADCP}$ expression occurred. In a large series of colorectal adenocarcinomas, however, we failed to find a uniform decrease of ADCP expression. Investigation of ADCP expression at the cellular level by radioimmunoassay $(7)$ and immunohistochemistry $(6,16)$ revealed striking intercellular heterogeneity in colorectal carcinomas. In view of the finding that the expression of ADCP in colorectal adenocarcinomas was correlated with that of secretory component we suggested that the ADCP expression might be of prognostic value in these tumors (6). In prostatic cancer patients the extent of tumor spread as reflected in the occurrence of metastases is an important prognostic variable. It would therefore be of great importance to lind markers that might predict the biological behavior (e.g. formation of metastases) of the primary prostatic carcinoma. With 
this aim we investigated the expression pattern of $A D C P$ in prostatic adenocarcinomas and compared this with the occurrence of metastases.

In our series of 30 prostatic adenocarcinomas we observed four distinct patterns of expression of ADCP. In 12 carcinomas we observed mainly cytoplasmic ADCP expression, in 11 mainly membranous expression was seen, in 2 we found cytoplasmic and membranous expression whereas in 5 no immunoreactivity was observed. Correlation of these expression patterns with the presence of metastases revealed that strong membranous ADCP expression occurred only in primary tumors without metastases, whereas in metastatic tumors no or mainly cytoplasmic ADCP immunoreactivity was found. These results indicate that the expression pattern of ADCP in human prostatic adenocarcinomas might predict whether or nor metastases are likely to occur.

It is generally assumed that undifferentiated tumors behave more agressively and show a higher tendency for metastatic spread than well differentiated tumors. The polar membranous pattern of ADCP expression in prostatic adenocarcinomas, which corresponds to the pattern of expression in the normal prostate, might indicate that these carcinomas are more highly differentiated. The finding that all the nonmetastatic well or well to moderately differentiated tumors showed strong membranous ADCP expression is in agreement with this assumption. In contrast, poorly differentiated carcinoma cells, which have a higher metastatic tendency, lose their polar characteristics and show diffuse cytoplasmic or no ADCP expression. In line with this view is the observation that in the prostatic carcinoma cell line xenografts apical membrane associated ADCP was found in the 2 moderately differentiated xenografts whereas 5 poorly differentiated xenografts were negative. However, one of these ADCP expressing moderately differentiated xenografts was established from a lymph node metastasis of a primary prostatic tumor. We could not study ADCP expression in the metastasis but the histological grade of the metastasis appeared to be comparable to the grade of the xenografts as was also the case for PC-82 (9). Most likely these results indicate that also tumors with membrane associated ADCP expression can metastasize. However, the possibility that in the metastasis of an undifferentiated tumor re-differentiation occurs can not be ruled out.

Comparison of the ADCP expression patterns with ultrastructural characteristics of cellular differentiation and determination of the ADCP expression patterns in metastases of prostatic adenocarcinomas can validate the suggestion that the expression pattern of ADCP is a parameter of differentiation and as such a predictor of the biological behavior of prostatic adenocarcinomas.

In summary, we demonstrated that in human prostatic adenocarcinomas membranous ADCP staining occurs preferably in tumors without metastases. Converse$1 y$, metastases seem to occur preferably in cases with no or only cytoplasmic ADCP staining. These observations suggest that immunohistochemical detection of ADCP might predict the biological behavior of prostatic cancer. This possibility should be confirmed in larger series of patients with sufficiently long follow-up. 


\subsection{References}

1. Dinjens WNM "Ten Kate J, van der Linden EPM, Wijnen JT, Meera Khan P, Bosman FT (1988). Distribution of adenosine deaminase complexing protein (ADCP) in human tissues. Submitted for publication (This thesis Chapter 4).

2. Herbschleb-Voogt E, Ten Kate J, Meera Khan P (1983) Adenosine deaminase complexing protein (ADCP): A transformation sensitive protein with potentials of a cancer marker. Anticancer Res. 3: $95=100$.

3. Inwood M, Povey S, Delhanty JDA (1980) Comparison of isozymes in fetal, adult and transformed fibroblasts. Cell Biol. Int. Rep. 4: 327-335.

4. Rutzky LP, Siciliano MJ (1982) Various isozyme gene expression patterns among thuman colorectal carcinoma cell lines and tissues. J. Natl. Cancer Inst. 68: 81-90.

5. Wright WC, Daniels WP, Fogh J (1981) Distinction of seventy-one cultured human tumor cellines by polymorphic enzyme analysis. J. Natl. Cancer Inst. 66: 239-247.

6. Ten Kate J, wan den Ingh HFGM, Meera Khan P, Bosman FT (1986). Adenosine deaminase complexing protein (ADCP) immunoreactiity in colorectal carcinoma. Int. J. Cancer 37: 479-485.

7. Ten Kate J., Wijnen JT, van der Goes $R G M$, Quadt $R$, Griffioen $G$, Bosman $\mathbb{E} T$, Meera Khan $P$ (1984) Quantitative changes in adenosine deaminase isozymes in human colorectal adenocarcinomas. Cancer Res. 44: 4688-4692.

8. McLean IW, Nakane PK (1984) Periodate-lysine-paraformaldehyde fixative. A new fixative for immunoelectronmicroscopy. J. Histochem. Cytochem. 22: 1077.

9. Van Steenbrugge GJ. Transplantable human prostatic cancer ( $\mathrm{PC}-82)$ in athymic nude mice: $\mathrm{A}$ model for the study of androgen-related tumor growth. Academic thesis, University of Rotterdam, 1988.

10. Hoehn W, Schroeder FH, Riemann JF, Joebsis AC, Hermanek P (1980) Human prostatic adenocarcinoma: Some characteristics of a serially transplantable line in nude mice (PC-82). Prostate 1: 195-104.

11. Hochn W, Wagner M, Riemann JF, Hermanek P, Williams E, Walther $\mathbb{R}$, Schrueffer R (1984) Prostatic adenocarcinoma PC-EW, a new human tumor line transplantable in mude mice. Prostate 5: 445-452.

12. Kaighn ME, Narayan KS, Ohmuki Y, Lechner JF, Jones LW (1979) Establishment of a human prostatic carcinoma cell line (PC-3). Invest. Urol. 17: 16-23.

13. Claas FHJ, van Steenbrugge GJ (1983) Expression of HLA-like structures on a permanent human tumor line PC-93. Tissue Antigens 21: 227-232.

14. Horoszewicz J, Leong S, Chu T, Wajsman Z, Friedman M, Papsidero L, Kim U, Chiu L, Kakati $S$, Arya $S$, Sandberg A (1980) The LNCaP cell line. A new model for studies on human prostatic carcinoma. Prog, Clin. Biol. Res. 37: 115-132.

15. Trotta PP, Balis $\mathrm{ME}$ (1978) Characterization of adenosine deaminase from normal colon and colon tumors. Evidence for tumor specific wariants. Biochemistry 17: 270-278.

16. Ten Kate J, Wijnen JT, Boldewijn J, Meera Khan P, Bosman FT (1985) Immunohistochemical localization of adenosine deaminase complexing protein (ADCP) in intestinal mucosa and in colorectal adenocarcinoma as a marker for tumour cell heterogeneity. Histochem. J. 17: 23-31. 


\section{Chapter 8}

\section{Expression of adenosine deaminase complexing protein $(\mathrm{ADCP})$ in human colorectal carcinoma cell lines*}

\subsection{Introduction}

Adenosine deaminase complexing protein (ADCP) is a ubiquitous glycoprotein predominantly present in plasma membranes with high concentrations in the prostate and in brushborders of epithelial cells of the proximal convoluted tubules in the kidney and of the intestinal tract (1-4). In the intestinal tract ADCP immunoreactivity was observed to be confined to the apical plasma membrane of the columnar epithelial cells. Goblet cells were negative $(2,4)$. In colorectal carcinomas a correlation was found between expression of $\mathrm{ADCP}$ and secretory component which led to the hypothesis that ADCP might be a marker for intestinal columnar cell differentiation (5). Furthermore, evidence was obtained that the ADCP expression pattern might be a reflection of the degree of differentiation of the epithelial cells $(2,5-7)$.

In the present study we investigated the relationship between ADCP expression and intestinal columnar epithelial cell differentiation in 4 human colorectal adenocarcinoma derived cell lines. We used the cell lines HT-29 and Caco-2 because they can express enterocytic differentiation features (enterocyte $=$ brushborder bearing resorptive columnar cell in the small intestine) (8). We also used the recently described cell lines 5583-E and 5583-S which were established from a single human colonic adenocarcinoma (9). The cell lines were cultured under several potentially differentiation modulating conditions $(8,10)$. These include addition of glucose, sodium butyrate ( $\mathrm{NaBT}$ ), dimethyl sulfoxide (DMSO) or retinoic acid (RA), omission of serum or replacement of glucose by inosine. The cell lines were also grown as xenograft in nude rats. As parameter for columnar (absorptive) enterocytic differentiation the expression of two microvillus associated proteins, villin and sucraseisomaltase, was used (11-14). By immunocytochemistry we compared the expession of ADCP with that of villin and sucrase-isomaltase.

"Dinjens WNM, Lenders MHJH, van der Linden EPM, Meera Khan P, ten Kate J, Bosman FT. Subrioitted for publication. 


\subsection{Materials and Methods}

\subsubsection{Chemicals and antibodies}

$\alpha-D-(+)$-glucose, butyric acid sodium salt (NaBT), RA and inosine were purchased from Sigma (St. Louis MO, USA). DMSO was obtained from Merck (Darmstadt, FRG). Diaminobenzidine tetrahydrochloride (DAB) was from Serva (Heidelberg, FRG). Anti-human sucrase-isomaltase monoclonal antibody (HBB2/614/88) was a generous gift of Dr. H.P. Hauri, Biozentrum der Universität Basel, Switzerland (14, 15). Anti-human villin monoclonal antibody was from Serotec (Blackthorn, UK) (16). Furthermore a rabbit anti-human ADCP antiserum was used (17).

\subsubsection{Cell lines}

The cultured cells were established lines derived from human colorectal adenocarcinoma. The cell lines HT-29 and Caco-2 were obtained from Dr. J. Fogh (Memorial Sloan Kettering Cancer Center, Rye, NY). Cell lines 5583-E and 5583-S were established at our institute and described elsewhere (9). In short 5583-E and 5583-S were estabished from a single primary colonic adenocarcinoma. 5583-E cells grow in epithelial layers, are clonogenic in soft agar and form poorly differentiated tumors in athymic mice. 5583-S cells grow in suspension in clusters, are not clonogenic in soft agar and form moderately to well differentiated tumors in athymic mice.

\subsubsection{Culture conditions}

The cells were cultured in Dulbecco's modified Eagle's minimum essential medium (DMEM, Flow Laboratories, Herts, UK) supplemented with 10\% inactivated $\left(56^{\circ} \mathrm{C}, 30 \mathrm{~min}\right)$ dialyzed fetal bovine serum (Hyclone, Logan UT, USA). The cells were seeded in plastic flasks (650 $\mathrm{cm}^{3}$ Falcon, Oxnard CA, USA) and cultured at $37^{\circ} \mathrm{C}$ in an atmosphere of $92.5 \%$ air $-7.5 \% \mathrm{CO}_{2}$. The treatment of cells with glucose, NaBT, DMSO or RA was started in the exponential growth phase by supplementing the medium with glucose ( $20 \mathrm{mM}$; final concentration $25 \mathrm{mM}$ ), NaBT (2 $\mathrm{mM})$, DMSO $(2 \% 0 \mathrm{v} / \mathrm{v})$, or RA $(35 \mu \mathrm{M})$. Cells were also cultured in serum free medium and in glucose free medium supplemented with $2.5 \mathrm{mM}$ inosine. The culture media were changed daily. Three different effects of the culture medium on cell growth were observed:

1. growth of the cells was not or only slightly affected

2. growth of the cells was strongly inhibited but the cells remained viable (assessed by microscopic examination and trypan blue dye exclusion) and

3 . cells did not remain vital.

When cell growth was not affected the cells were harvested after 10 passages, in exponential and in confluent growth conditions. When cell growth was strongly inhibited but the cells remained viable, cells were harvested after $20-30$ days. The cells 
were passaged by standard trypsinization. After trypsinization of cells grown in serum free medium, the cells did not adhere to the culture flask when re-seeded in serum free medium. Addition of serum restored the adhering capacity of the cells. Therefore cells were cultured in serum free medium only for 20-30 days and harvested in the exponential growth phase.

\subsubsection{Tumors in nude rats}

Harlem Sprague Dawley athymic nu/nu male rats of 8 -10 weeks old were inoculated subcutaneously with $2 \times 10^{6}$ tumor cells in PBS. Tumors were obtained from all 4 cell lines. Tumors were excised depending upon the size $\left(\max 1 \mathrm{~cm}^{3}\right) 20-50$ days after inoculation and snap frozen in isopentane, quenched in dry-ice $\left(-80^{\circ} \mathrm{C}\right)$, for immunohistochemistry.

\subsubsection{Immunocytochemistry}

The cultured cells were harvested by gentle scraping with a rubber policeman. Attention was paid to preserve the intercellular adhesions as much as possible. The cells were fixed in $70 \%$ ethanol in PBS for $20 \mathrm{~min}$ at $4^{\circ} \mathrm{C}$. After washing the pellet was resuspended in $5 \% \%(\mathrm{v} / \mathrm{V})$ agar in $\mathrm{PBS}\left(\right.$ at $56^{\circ} \mathrm{C}$ ) and immediately cooled to $4{ }^{\circ} \mathrm{C}$. The agar block was subsequently embedded in paraffin according to routine procedures. Paraffin sections $(4 \mu \mathrm{m})$ were rehydrated prior to immunocytochemistry. Cryostat sections $(4 \mu \mathrm{m})$ of the xenografts were dried and fixed in periodate-lysineparaformaldehyde (18) for 10 min at RT. After washing in PBS endogenous peroxidase activity was blocked by incubating the sections for 30 min at RT in PBS containing $0.5 \%(\mathrm{v} / \mathrm{v})$ hydrogen peroxide. The standard procedure for the indirect immunoperoxidase technique was followed. Prior to application of the polyclonal anti-ADCP antiserum the preparations were preincubated with $20 \%(\mathrm{v} / \mathrm{v})$ normal goat serum to reduce non-specific binding. Peroxidase activity was visualized using diaminobenzidine hydrochloride (DAB) as the substrate and the preparations were slightly counterstained with hematoxylin.

\subsubsection{Electronmicroscopy}

After harvesting, the cells were fixed in $2.5 \%$ glutaraldehyde in $0.1 \mathrm{M}$ sodium phosphatebuffer $\mathrm{pH} 7.2$, postfixed $1 \mathrm{~h}$ in $1 \% \%$ osmium tetroxide, dehydrated in a graded series of alcohols and embedded in Epon. Ultrathin sections where stained with uranylacetate and leadcitrate.

\subsection{Results}

In Table I the effects of the culture conditions on growth and viability of the cells 
Table 1 Effect of culture conditions ${ }^{1}$ on growth and viability of the cells ${ }^{2}$

\begin{tabular}{|c|c|c|c|c|c|c|c|c|}
\hline \multirow[t]{2}{*}{ Cell line } & \multicolumn{2}{|c|}{$\begin{array}{l}\text { - glucose } \\
+ \text { inosine }\end{array}$} & \multicolumn{2}{|c|}{$\mathrm{NaBT}$} & \multicolumn{2}{|c|}{ DMSO } & \multicolumn{2}{|c|}{$\begin{array}{l}\text { Serum } \\
\text { deprived }\end{array}$} \\
\hline & $\mathrm{G}$ & V & $\mathrm{G}$ & $\mathrm{V}$ & $\mathrm{G}$ & $v$ & $\mathrm{G}$ & $\mathrm{V}$ \\
\hline HT-29 & to & + & + & + & - & + & + & + \\
\hline Caco-2 & + & + & - & + & - & + & + & + \\
\hline $5583-E$ & - & + & - & + & - & + & to & + \\
\hline $5583-5$ & - & + & + & + & - & + & - & - \\
\hline
\end{tabular}

1 For details see Materials and Methods

2 Growth $(G)$ and viability (V) are indicated as + or -

are listed. Cell growth and viability were not affected by addition of glucose or RA. Substitution of glucose by inosine reduced growth but not the viability of 5583-E and 5583-S cells. Similarly, addition of NaBT in Caco-2 and 5583-E and of DMSO in all cell lines reduced growth but not viability. Growth and viability of 5583-S cells were reduced by serum deprivation.

The results of the immunocytochemical studies on cell lines grown in vitro are listed in Table II. Villin and sucrase-isomaltase reactivity was observed exclusively along the apical plasma membrane of the cells. Strong cytoplasmic ADCP expression was always accompanied by membrane associated expression. In multilayered cell groups only the superficial cell layer expressed the membrane associated antigens. In confluent HT- 29 cells cultured in the presence of inosine formation of intracellular lumina was observed. These lumina showed marginal plasma membrane staining for villin, sucrase-isomaltase and ADCP (Fig. 1). Ultrastructurally, these cells showed intracytoplasmic lumina with a well developed brush border-like margin

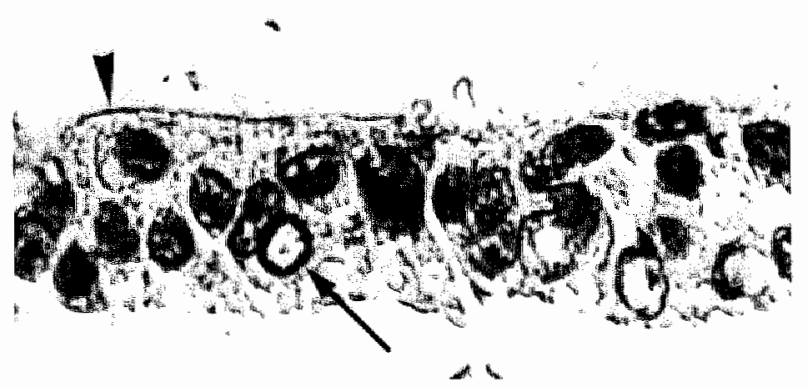

Fig. 1. HT-29 cells at confluency, grown in the presence of inosine, showing a small intracytoplasmic lumen with marginal reactivity for ADCP (arrow). Also weak apical membrane associated ADCP immunoreactivity is observed (arrowhead) (immunoperoxidase, $750 \times)$. 


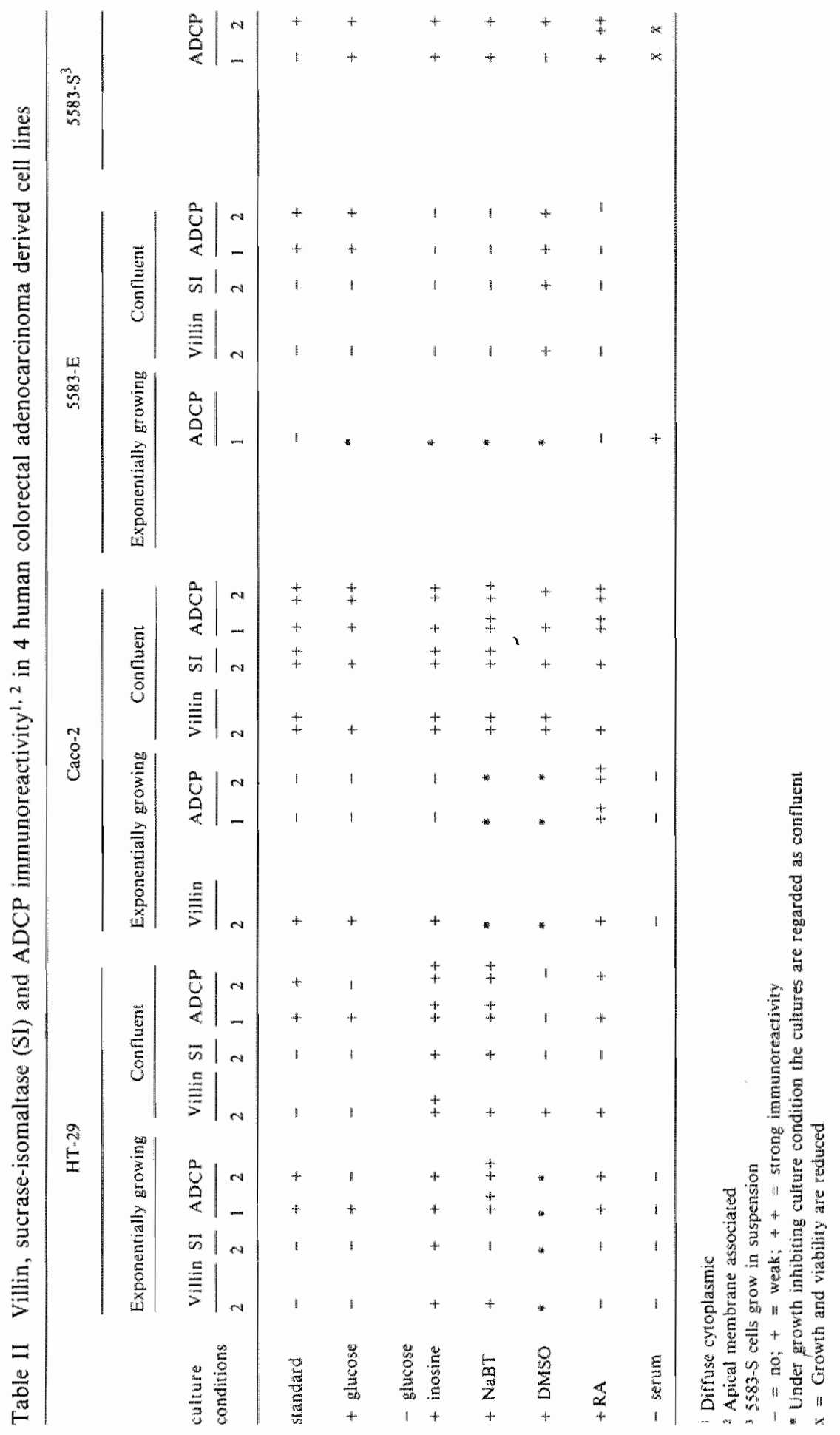



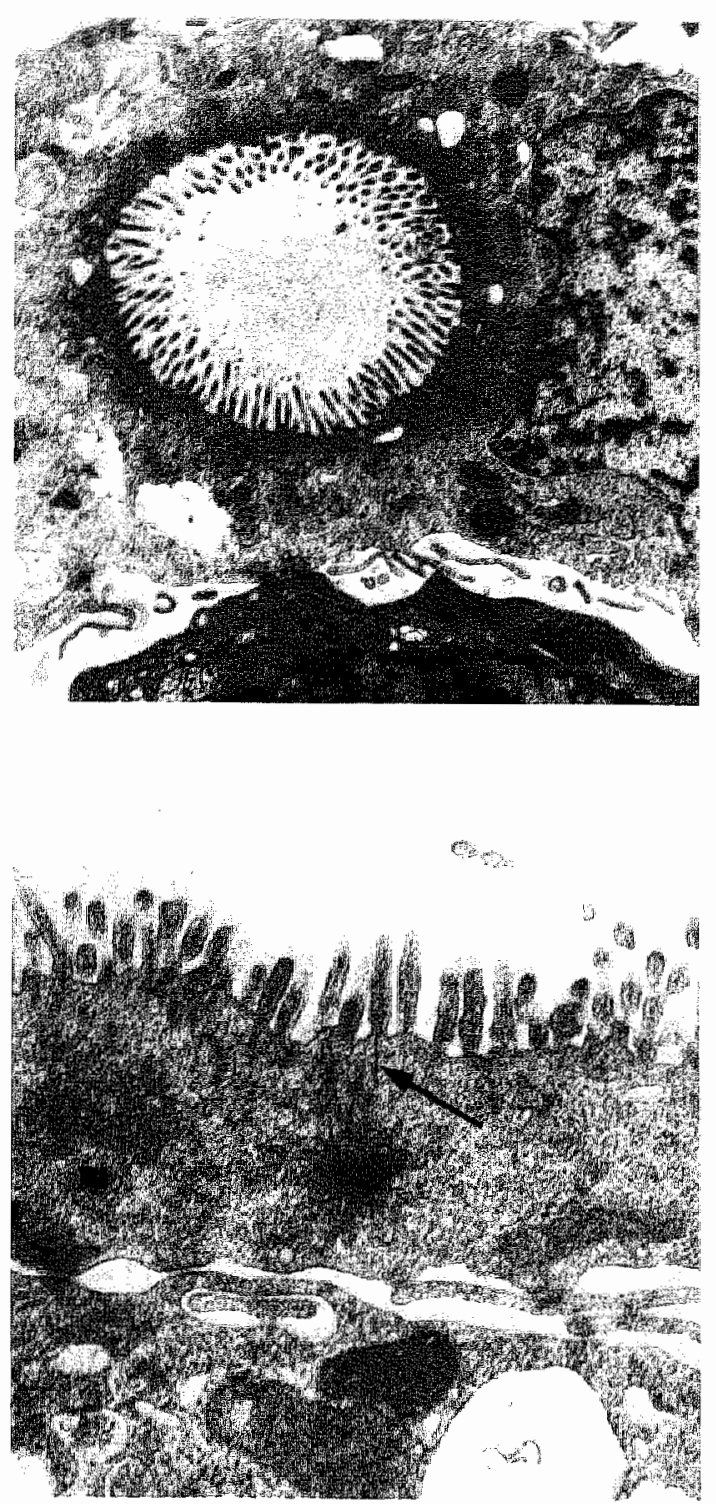

Fig. 2. HT-29 cells at confluency, grown in the presence of inosine, showing an intracytoplasmic lumen with a well developed brush border-like margin $(8000 \times)$.
Fig. 3. HT-29 cells at confluency, grown in the presence of inosine, showing surface microvilli with characteristic axonemata (arrow) $(26400 \times)$.

(Fig. 2) and a surface structure characterized by microvilli with characteristic axonemata (Fig. 3). In HT-29 cells cultured in the presence of glucose surface microvilli were rare (not shown). Except for HT-29 cells cultured in the presence of DMSO, villin reactivity was always accompanied by $A D C P$ expression. Reactivity of sucrase-isomaltase was always found in combination with villin and ADCP expression. However, ADCP reactivity was not always accompanied by villin or sucraseisomaltase reactivity and similarly villin was observed without sucrase-isomaltase expression. Under standard culture conditions and at confluency Caco-2 showed 
expression of ADCP (Fig. 4), willin (Fig. 5) and sucrase-isomaltase, HT-29 did not express villin and sucrase-isomaltase and 5583-E and 5583-S showed only weak ADCP expression. Compared to the level of expression in the exponential growth phase, confluent Caco-2 cells showed an increased expression of ADCP, villin and sucrase-isomaltase whereas in 5583-E cells only ADCP expression increased. Antigen expression in cells cultured under growth inhibitory conditions was compared with the expression in cells grown under standard conditions and harvested at confluency. Replacement of glucose by inosine or addition of NaBT resulted in an increase in villin, sucrase-isomaltase and ADCP expression in HT-29 cells compared to standard culture conditions, whereas in $5583 \times \mathrm{S}$ cells only the cytoplasmic expression of ADCP increased. Under these conditions only marginal differences were observed in Caco-2 cells, and in 5583-E cells the expression of ADCP decreased. Addition of DMSO induced in 5583-E cells a weak expression of membrane associated villin (Fig. 6) and sucrase-isomaltase. DMSO reduced the sucrase-isomaltase and ADCP reactivity in Caco-2 cells whereas ADCP expression in HT-29 cells was completely abolished. Addition of glucose reduced or did not aiter the expression of villin, sucrase-isomaltase and ADCP in Caco-2, HT-29 (Fig. 7) and 5583-E cells. However, in 5583-S cells glucose enhanced the cytoplasmic ADCP expression.

RA thad an inhibiting effect on expression of sucrase-isomaltase and villin in Caco-2 cells and on ADCP reactivity in 5583-E cells. On the contrary RA strongly enhanced the expression of ADCP in Caco-2 and 5583-S cells. Serum deprivation reduced villin expression in Caco-2 cells and ADCP expression in HT-29 and 5583-E cells. However, after 22 days of serum deprivation. HT-29 cells demonstrated production of mucins (Fig. 8). Immunohistochemistry applied on nude rat xenografts of the cell lines revealed that in all xenografts apical membrane associated reactivity with antiADCP (Fig. 9) and anti-villin occurred, whereas in the 5583-E xenograft no reactivity with anti-sucrase-isomaltase was observed and in 5583-S xenografts only weak membrane associated reaclivity (Table $\mathrm{HI}$ ).

\subsection{Discussion}

The human colon carcinoma cell lines HT-29 and Caco-2 have the potential to express characteristics of enterocytic differentiation in vitro and in vivo $(14,19-23)$. These characteristics include the presence of junctional complexes and the development of cell polarity, more specifically the occurrence of a brushborder and the expression of structural (villin) or functional (sucrase-isomaltase, aminopeptidase $\mathrm{N}$, dipeptidylpeptidase IV, lactase, alkaline phosphatase) brushborder associated proteins (16,21-23). Brushborders and their associated proteins normally occur in small intestinal columnar cells, which, together with the emergence of small intestinal types of mucin (sialomucin) in colon cancer (24), underlines the aberrant nature of epithelial cell differentiation in colon carcinoma cells. Nevertheless, HT-29 and Caco- 2 cells are useful models for the study of small intestinal epithelial differentiation $(19,25,26)$. 


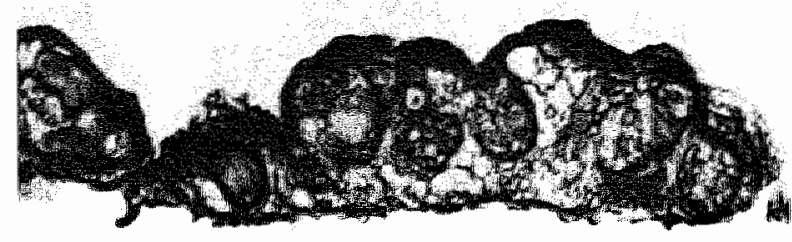

Fig. 4. Caco-2 cells at confluency stained for ADCP showing strong apical membrane associated and weak cytoplasmic reactivity (immunoperoxidase, $1200 \times$ ).

Fig. 5. Caco-2 cells at confluency stained for villin showing strong apical membrane associated reactivity (immunoperoxidase, $750 x$ ).

Fig. 6. 5583-E cells cultured in the presence of DMSO showing weak apical membrane associated villin expression (arrow) (immunoperoxidase, $400 \times$ ). 
Fig. 7. HT-29 cells at confluency, grown in the presence of $25 \mathrm{mM}$ glucose. Note that growth occurs in multicell layers. Weak cytoplasmic $A D C P$ reactivity is observed (immunoperoxidase, $500 x$ ).

Fig. 8. Diamine/Alciam Blue staining of HT-29 cells grown without serum. Mucin vacuoles indicating the emergence of goblet-like cells can be noted (arrow) $(750 \times)$.

Fig. 9. Rat xenograft of HT-29 stained with antiADCP antiserum showing strong luminal membrane associated and weak cytoplasmic reactivity for ADCP (immunoperoxidase, $250 \times)$.
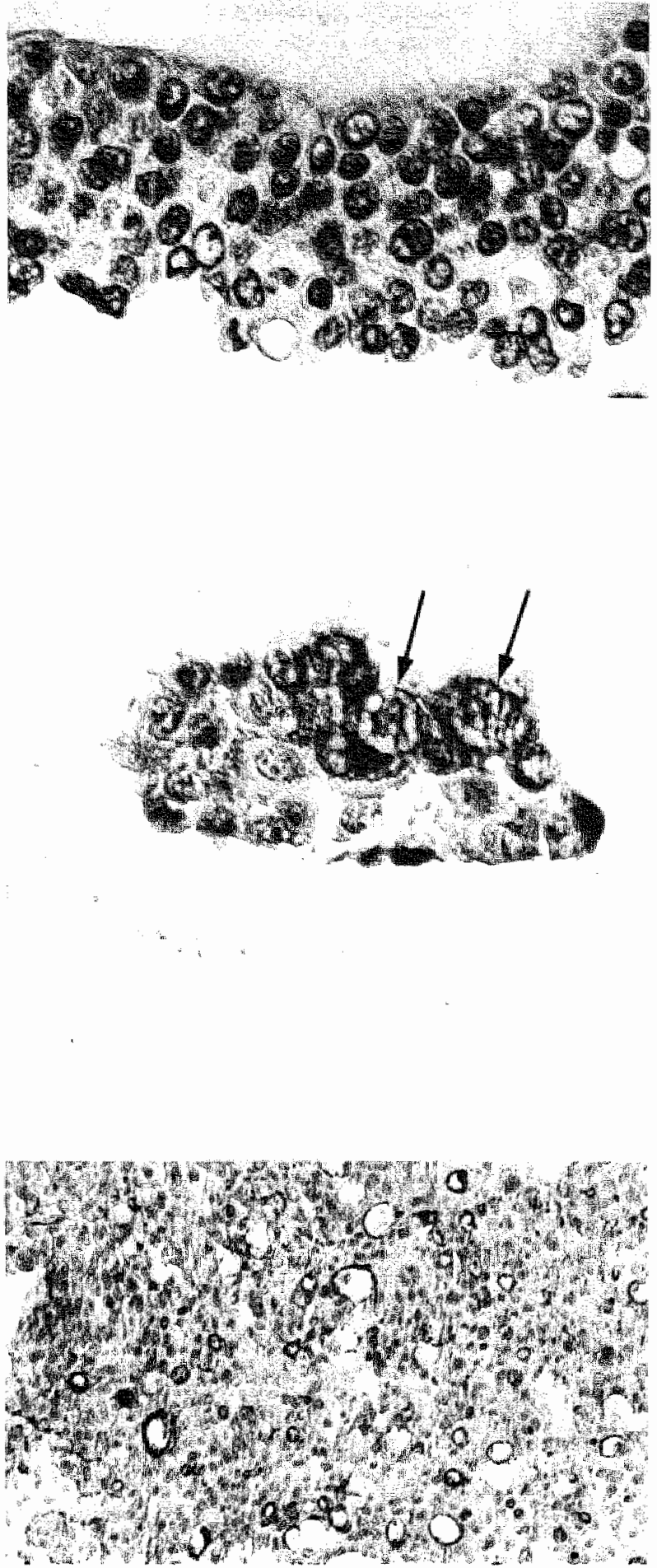
Table III Villin, sterase-isomaltase (SI) and ADCP immunoreactivity ${ }^{2}$ in rat xenografts

\begin{tabular}{|c|c|c|c|c|c|c|}
\hline \multirow[t]{2}{*}{ Cell ine } & \multicolumn{2}{|c|}{ villin } & \multicolumn{2}{|c|}{ SI } & \multicolumn{2}{|c|}{ ADCP } \\
\hline & 1 & 2 & 1 & 2 & 1 & 2 \\
\hline HT-29 & 4 & ++ & + & $+t$ & + & $+t$ \\
\hline Caco-2 & + & + & + & $+t$ & + & ++ \\
\hline $5583-\mathrm{E}$ & 4 & ++ & - & - & 4 & ++ \\
\hline $5583-\mathrm{S}$ & 4 & $+t$ & - & + & + & $+t$ \\
\hline
\end{tabular}

Diffuse eytoplasmic

2 Apical membrane associated

$-=\mathrm{no}+=$ weak; $++=$ strong reactivity

Caco- 2 cells show enterocytic differentiation at late confluency under standard culturing conditions whereas HT-29 cells sustain this type of differentiation in medium without hexoses $(8,20,21,23,27)$. After serum deprivation a subpopulation of H'T-29 cells differentiates into goblet-like cells (28) and also into Paneth-like cells, as evidenced by the production of lysozyme $(29,30)$. Other agents, such as NaBT, DMSO and RA induce HT-29 cells to display one or more of these characteristics of enterocytic differentiation (10,31-33). In contrast, culturing of HT-29 cells in medium containing $25 \mathrm{mM}$ glucose has been shown to induce an undifferentiated phenotype (23).

Our data with regard to villin and sucrase-isomaltase expression in HT-29 and Caco-2 cells under various conditions, are in agreement with the literature (14, 19-23). We did, however, not observe cytoplasmic villin reactivity in undifferentiated HT-29 cells as reported by others (34). The reduced expression of sucraseisomaltase and villin by Caco- 2 cells as induced by glucose, DMSO and RA and the enhanced expression of villin in NaBT treated HT-29 cells are new findings. It is clear that growth inhibition in Caco-2 cells (either in confluency or after addition of NaBT or DMSO) is not invariably followed by differentiation. When grown under standard conditions $5583-\mathrm{E}$ cells are undifferentiated whereas $5583-\mathrm{S}$ cells express a more differentiated goblet cell like phenotype although columnar cells with well developed microvilli occur also (9). Evidently, the induction of differentiation requires from cell line to cell line different specific signals.

In 5583-E cells DMSO induced enterocytic differentiation with expression of villin and sucrase-isomaltase. In 5583-S cells immunocytochemistry failed to reveal enterocytic differentiation, despite the fact that some of these cells showed microvillous surface differentiation by electron microscopy (9). Conceivably, in these cells the level of expression of villin is so low that it can not be detected by immunocytochemistry. It is also possible that an altered protein is produced, which is not recognized by the anti-villin monoclonal antibody. Le Bivic et al. (35) also reported the presence of microvilli on undifferentiated HT- 29 cells without concomitant villin immunoreactivity. 
The mechanisms by which the various culture conditions modulate cellular differentiation are not well understood, however, a number of effects have been described. High glucose concentrations in the medium are reported to result in high intracellular concentration of UDP-N-acetylhexosamines (22). An increase of these compounds has been shown in undifferentiated cells to reflect an impairment of protein glycosylation (8). Also a close relationship between energy metabolism and intracellular protein breakdown has been demonstrated. Glucose deprivation prevented lysosomal protein breakdown (8). NaBT is known to induce hyperacetylation of histones through inhibition of histone deacetylase and it has been suggested that this process is involved in the regulation of gene expression (36). DMSO alters membrane permeability and microviscosity and causes single-strand breaks in the DNA (37). Retinoids are thought to act like steroid hormones by forming a complex with a binding protein which is translocated into the nucleus causing alterations in gene expression (38).

Both 5583-E and 5583-S cells, grown as xenografts in nude rats, expressed villin whereas only $5583-\mathrm{S}$ showed membranous sucrase-isomaltase reactivity. This suggests that 5583-S cells have reached a higher level of differentiation, assuming that along the process of differentiation sucrase-isomaltase expression is acquired later than microvillus formation. This corresponds with the earlier reported morphological characteristics (9).

The expression of villin and sucrase-isomaltase in neoplastic colorectal epithelia are well accepted characteristics of enterocytic differentiation (14, 16). ADCP immunoreactivity has been previously described in columnar cells in the large and small intestine (4) and its apical membrane associated reactivity was suggested to be indicative for polar, microvilli bearing cells $(2,4,5)$. To elucidate the usefulness of ADCP as a marker of enterocytic differentiation we correlated its expression with that of villin and sucrase-isomaltase on the 4 cell lines grown in vitro and in vivo in nude rats. The finding that membrane associated sucrase-isomaltase reactivity is always accompanied by membranous villin expression was expected, because membranous localization of sucrase-isomaltase has been described exclusively in cells containing well developed microvilli (11-14). Except for HT-29 cells cultured with DMSO, villin expression was always found in combination with ADCP expression but ADCP reactivity also occurred without villin expression. The strongest membrane associated ADCP reactivity always occurred in well differentiated cells but usually in combination with cytoplasmic reactivity. In normal intestinal cells ADCP reactivity is not found in the cytoplasm whereas in colorectal carcinoma cytoplasmic ADCP expression is frequently observed (2, 4-6). Cytoplasmic ADCP expression may indicate loss of cell polarity. Cell polarity is generally regarded as a characteristic of the differentiated state. In reviewing these data it is tempting to speculate that the expression of villin, sucrase-isomaltase and ADCP might represent different levels of enterocytic differentiation.

The xenograft experiments demonstrate that all 4 cell lines when exposed to an appropriate environment have the potential to differentiate as enterocytes. Recently 
It has been shown that xenografts of Caco- 2 contain columnar, goblet and neuroendocrine cells. HT-29 xenografts only showed columnar and neuroendocrine cells (39). In vitro, HT-29 cells can also differentiate as goblet cells (28) and Paneth cells $(29,30)$. Cell lines 5583-E and 5583-S grown as xenografts showed goblet and columnar cell differentiation, neuroendocrine and Paneth cells were not observed (39). These results indicate 1 . that under in vitro conditions these cell lines show a more limited repertoire of differentiational characteristics than under in vivo conditions and 2 , all 4 cell lines harbor relatively undifferentiated cells which have retained the propensity to differentiate into different directions. These cells might be multipotent "tumor stem cells" at various levels of maturation. Recently Kirkland (40) demonstrated that a single human rectal adenocarcinoma cell can differentiate into columnar, goblet and endocrine cells. Her results support the unitarian stem cell hypothesis for cell renewal in colorectal epithelium. The exploration of refined markers for stages of differentiation of different types of intestinal cells will increase our understanding of normal and neoplastic intestinal epithelial cell differentiation. This knowledge might lead to biologically relevant as well as clinically useful new classifications of colorectal carcinoma. In the search for such differentiation markers cell lines with different differentiating capabilities might prove helpful.

In summary, these studies show that :

1. 5583-E and 5583-S cells show a more limited propensity towards enterocytic differentiation than Caco-2 and HT-29 cells;

2. In vivo these cell lines show a more extensive repertoire of differentiational capabilities than in vitro;

3. ADCP is predominantly expressed in cells with columnar differentiation and is probably an earlier appearing marker in this cell lineage than the endstage markers villin and sucrase-isomaltase.

4. Growth and differentiation are separately regulated cellular processes in colorectal carcinoma cell lines.

\subsection{References}

1. Schrader WP, Bryer PJ (1982) Characterization of an insoluble adenosine deaminase complexing protein from human kidney. Arch. Biochem. Biophys. 215: 107-115.

2. Ten Kate J, Wijnen JT, Boldewijn J, Meera Khan P. Bosman FT (1985) Immunohistochemical localization of adenosine deaminase complexing protein (ADCP) in intestinal mucosa and in colorectal adenocarcinoma as a marker for tumour cell heterogeneity. Histochem. J. 17: 23-31.

3. Finstad CL, Cordon-Cardo C, Bander NH, Whitmore WF, Melamed MR, Old LJ (1985) Specificity analysis of mouse monoclonal antibodies defining cell surface antigens of human renal cancer. Proc. Nall. Acad. Sci. USA 82: 2955-2959.

4. Dinjens WNM, ten Kate J, van der Linden EPM, Wijnen JT, Meera Khan P, Bosman FT. Distribution of adenosine deaminase complexing protein (ADCP) in human tissues. Submilted for publication (This thesis Chapter 4). 


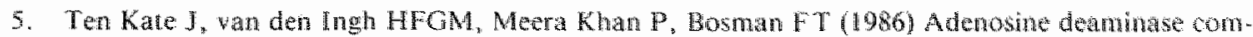
plexing protein (ADCP) immunoreactivity in colorectal carcinoma. Int. I. Cancer $37: 479485$.

6. Dinjens WNM, van der Linder EPM, Lenders MHJH, ten Kate J, Meera KMan P, Bosman T. Adenosine deaminase complexing protein (ADCP) immonoreactivity in adenocamonomas. Submil sed for pullication (This thesis Chapter 6 ).

7. Dinjens WNM, ten Kate J, Kirch JA JM, van der Linden EPM, Tanke H, Jonus U, wan den Ingh HFGM, Meera Khan P, Bosman FT. ADCP expression and merastatio polential in prosatic adenocarcinomas. Submitted for publination (This thesis Chapter 7 ).

8. Rousset $M$ (1986) The human colon carcinoma cell lines HT-29 and Caco2: two in vitro models lor the study of intestinal differentiation. Biochimia $68 \% 1035$ w1040.

9. Verstijnen CPHA, Arends JW, Moerkerk PTM, Geraedrs IPM, Uitendaal MP, Bosman FT (1987) Two new colonic carcinona cell hines derived from one human colontic ad nocatomona: establishment and characterization. Wirch. Arch. B. 53: 191-197.

10. Tsao D, Morita A, Bella A, Luu P. Kim YS (1982) Differential effects of sodiun bulynate, dimethyl sulfoxide, and refinoic acid on membrane-associated antigen, enzymes and glycoproteins of hunnan rectal adenocarcinoma cells. Cancer Res. 42: 1052-1058.

11. Bretscher $\mathrm{A}$, Weber $\mathrm{K}$ (1980) Villin is a major protein of the microvillus cyloskelaron whint binds both $G=$ and F-actin in a calcium-dependent mannen. Cell 20: 839-847.

12. West AB, Isaac CA, Cartoni JM, Morrow AS, Mooseker MS, Barwick KW (1988) Localization of villin, a cytosketal protein specific to microvilli, in human illeum and colon and in colonic veoplasms. Gasitroentenal. 94: 343-352.

13. Kenny AJ, Maroux S (1982) Topology of microvillar membrane hydrolases of kidney and intesthe. Physiol. Rev, 62: 9 -128.

14. Zweibrum A, Hauri HP, Sterch E, Chantret L, Haffen K, Bamat J, Sordai B (1984) Immunohistological evidence, obtained with monoclonal antibodies, of small intestinal brush border hydrolases in human colon cancers and foetal colons. Int. J. Cancer 34: 591-598.

15. Hauri HP, Sterchi E, Bienz D, Fransen JAM, Marxer A (1985) Expression and intracellulat transport of microvillous hydrolases in human intestinal epithelial cells. J. Cell Biot. 101: 838-85

16. Robine S, Huet C, Mole R, Sahuquillom Merino C, Coudriter E, Zweibaun A, Louward D (1985) Can villin be used to identify malignant and undifferentiated nomal digestive epithellal cells" Proc. Natl. Acad. Sci. USA 82: 8488-8492.

17. Ten Kate J, Wijnen JT, Van der Goes RGM, Quadi R, Griffioen G, Bosman FT, Meera Khan P (1984) Quartitative changes in adenosine deaminase isozymes in thman colorectal adenocarcino. mas. Cancer Res. 44: 4688-4692.

18. MeLean IW, Nakane PK (1974) Periodate-lysine paraformalldelyde fixalive. A new fixarive for inmunoelectronmicroscopy. 1. Histochem. Cytochem. 22: 1077.

19. Zweibaum A. Triadou N, Kedinger M, Augeron C, Robine-Leon S, Pinto S, Rousset M, Mullen K (1983) Sucrase-isomaltase: a marter of foetal and malignant epithelial cells of the human colon. Lnt. J. Cancer 32: 407-412.

20. Pinto M. Robine-Leon S, Appay MD, Kedinger M, Triadou N, Dussandx E, Lacroix B, SinonAssmann P, Haffen K, Fogh J, Zweibaum A (1983) Enierocyte-like differentiation and polarization of the human colon carcinoma cell line Caco-2 in cultute. Biol. Cell 47: 323 -330.

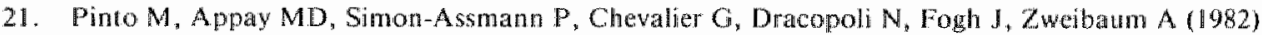
Enterocytio differentiation of cultured buman colon wancer cells by replacement of gluoses by galactose in the medium. Biol. Cell 44: 193-196.

22. Wice $B M$, Trugnan $G$, Pinto M, Rousset $M$, Chevalier G, Dussaulx E, Lacroix B, Zweibaum A (1985) The intracellalar accumulation of UDP.N-acetylhexosamines is concomittant with the inability of human colon cancer cells to differentiate. J. Biol. Chem. 260: 139.146. 
21. Zwoibum A, Finto M, Chewaller $G$, Dusaux $E$, Triadon $N$, Lacroix $B$, Haffem K, Brun JL. Rouse M (1985) Enterocytic diferentiation of a subpopulation of the humin colon tumor cell line HT.29 selected hor growh in sugar free medium and its inhibition by glucose. J. Cell Physiol. 122 : $21-29$.

24. Fine MI (1979) Mucins in the human gastrointestinal epithelum: a review. Invest. Cell Pathol. $2: 195-216$.

25. Mooseker MS (1985) Organisation, chemistry, and assembly of the cycoskeletal apparatus of the intestinal brusth border. Ann. Rev. Cell Biol. 1: 209-241.

26. Fransen لAM, Ginsel LA, Haur HP, Sterchi E, Blok J (1985) Immunoelectronmicroscopical localization of a microvilus membrane disaccharidase in the human small-intestinal epithelium with monoclonal artibodies. Eur. J. Cell Biol. 38: 6-15.

27. Rousset M, Laburthe M, Pinto M, Chevalier $G$, Rouyer Fessard C, Dussaut E, Trugnan G, Boige N, Brun JL, Zweibatum A (1985) Enterocytic differentiation and glucose vthization in the human colon tumor cell line Caco-2: modulation by forskolin. J. Cell Physiol. 123: 377-385.

28. Huet C, Sahuquillo-Merino $C$, Coudrier $E$, Louvard D (1987) Absorptive and mucus-secreting subchones isolated from a multipotent untestinal cell line (HT-29) provide new models for cell polarity and terminal differentiation. J. Cell Biol. 105: 345-357.

29. Alderman EM, Lobb RR. Fett JW (1985) Isoletion of tumormsecreted products from tuman carcinorra cells mantaned in a defined protein-free medium. Proc. Natl. Acad. Sci. USA 82: $5771-5775$.

30. Fett JW, strydom DJ, Lobb RR, Alderman EM, Vallee BL (1985) Lysozyme: a major secretory product of a human colon carcinoma cell line. Biochemistry 24 : $965-975$.

31. Kum YS, Tsao D, Siddiqui B, Whitehead JS, Arnstein P, Bennett J, Hicks J (1980) Effects of sodium butyrate and dimethylsulfoxide on biochemical properties of thuman colon cancer cells. Cancer 45: $1185-1192$

32. Herz F, Schermer A, Halwer M, Bogart LH (1981) Alkaline phosphatase in HT-29, a human colon cancer cell line: Intluence of sodiun butyrate and hyperosmolarity. Arch. Biochem. Biophys. 210 : $581-591$

33. Augeron C, Laboisse CL (1984) Emergence of permanently differentiated cell clones in a human colonic cancer cell line after treatment with sodium butyrate. Cancen Res. 44: 3961-3969.

34. Dudouet B, Robine S, Huet C, Sahuquillo-Merino C, Blair L, Coudrier E, Louvard D (1987) Changes in villin synthesis and subcellular distribution during intestinal differentiation of HT29 18 clones. J. Cell Biol. 105: 359-369.

35. Le Bivie A, Hirn M, Reggio H (1988) HT-29 cells are an in wiro model for the generation of cell polarity in epithelia during embryonic differentiation. Proc. Nall. Acad. Sci. USA 85: 136-140.

36. Boffa LC, Vidali G, Mann RS, Allfey VG (1978) Suppression of histone deacetylation in wivo and in vitro by sodium butyrate. J. Biol. Chem. 253: 3364-3366.

37. Terada M. Nudel U, Fibach E, Rilkind RA, Marks PA (1978) Changes in DNA associated with induction of erythroid differentation by dimethyl sulfoxide in murine erythroheukemia cells. Cancer Res. 38" 835.840 .

38. Lotan R (1980) Effects of vitamin A and äts analogs (ret noids) on normal and neoplastic cells. Biochim. Biophys. Acta 605: 83-91.

39. Schutte B. Cancet cell ploidy and proliferation in colorectal carcinoma. Acadernic thesis, Universily of Limburg, 1987 .

40. Kirkland SC (1988) Clonal origin of columnar, mucous, and endocrine cell lineages in haman colorectat apithetium. Cancer 61: 1359-1363. 


\section{Chapter 9}

\section{General discussion}

\subsection{Introduction}

In this final chapter the results of the investigations described in the previous chapters are discussed, particularly in relation to the possible physiological function of ADCP and its significance as a marker in neoplastic transformation.

\subsection{Physiological function of ADCP}

ADCP was discovered about 15 years ago by biochemical investigation devoted to the enzyme adenosine deaminase (ADA) (1). The observed binding property of ADA to ADCP (2) has led to the speculation that the physiological function of ADCP is related to its binding to ADA (3-8). However, as yet the various theories concerning an ADA related function of ADCP have not been proven. None of these theories consider the possibility that ADCP might have an enzymatic activity related to adenosine deamination. Several multienzyme complexes have been described and they all facilitate the passage of reaction intermediates directly from one enzyme to another (9). For ADA a purine 5'nucleotidase complex would be a candidate. This dimeric enzyme converts adenosine monophosphate into adenosine and inorganic phosphate and it has a predominant plasma membrane associated localization. However, its apparent subunit molecular weight is below the ADCP subunit molecular weight $(10,11)$. All the theories of an ADA related function of ADCP are based on the tight binding capacity of ADCP for ADA. This tight binding of ADCP to ADA, so far only proven in cell lysates, need not necessarily point to a physiological role for this binding. Tight and specific interactions have been described between physiologically independent proteins (12).

Evidence is being accumulated at present, that the function of $A D C P$ is not related to ADA. This suggestion is derived from the observed lack of co-localization of ADCP and ADA as determined by immunohistochemical investigations (13-16). The evidence with regard to the occurrence of $\mathrm{ADCP}$ in murine tissue extracts that do not show ADA binding capacity, as described in chapter 3, also argues against an ADA related function for ADCP. The question remains: What is the function of ADCP? Though its capacity to bind ADA has not been proven to be of physiological significance, this possibility can not be completely excluded. The fact that the protein is glycosylated suggests that its function is plasma membrane associated 
and/or associated with the cellular process of secretion. Its predominant association with plasma membranes and its presence in secretory fluids $(6,8,14,15-18)$ is in accordance with this suggestion. The expression of ADCP in endometrial glands exclusively during the secretory phase, and the expression in epithelial cells at the secretory pole of the cells (e.g. prostate, salivary and sweat glands) strongly suggests a secretion related function of $A D C P$ (18). On the other hand, abundant ADCP expression also occurs in cells without a secretory function (e.g. epithelial cells of the proximal convoluted tubules of the kidney and fibroblasts) whereas some secretory cell types (e.g. mucus secreting cells in the gastrointestinal tract) do not express ADCP. Absence of ADCP was also reported for some normal cell types (such as erythrocytes) and for tumor derived and virus transformed cell lines (19-22). Therefore, ADCP is neither an obligatory membrane protein nor an obligatory secretory protein. It is not unlikely, however, that when ADCP is present in secretory cells its function might be related to the secretory process. Because of abundant ADCP expression in absorptive epithelial cells at the absorptive pole of the cells (intestine, renal proximal convoluted tubules) (18) it is tempting to speculate that in these cells the function of ADCP is related to the absorptive process. In non-secretory and non-absorptive cells its function might be related to the maintenance of structural or functional integrity of the membrane. These assumptions would imply a multifunctional physiological role for ADCP. Multifunctional proteins are well known and include hormones, enzymes and growth factors. It has to be stressed here that these reflections on the function of $\mathrm{ADCP}$ are mainly based upon immunohistochemical identification of this protein. With this technique low levels of ADCP might escape detection, which limits the validity of speculations solely based upon immunohistochemical observations.

\section{3 $\mathrm{ADCP}$ and neoplastic transformation}

During the last decades many efforts have been made to find tumor associated antigens with cliagnostic, prognostic or therapeutic usefulness in the management of cancer patients. The establishment of the hybridoma technique for the production of monoclonal antibodies (23) created expectations that new tumor antigens would be discovered with high tumor specificity. The assumption behind these thoughts was based on the theory of Ehrlich, proposed at the beginning of this century, that cells in the process of neoplastic transformation acquire tumor specific antigens (24). However, despite immense effort, no truly tumor specific antigens have been found as yet. Although tumor specific antigens are probably present in some tumors (e.g. proteins encoded by viral genes in tumors induced by virus infection or neoantigens encoded by hybrid genes generated by cancer specific intergenic recombinations can be regarded as tumor specific (25-29)), malignant transformation is more and more regarded as a process of disturbed normal regulation rather than the acquisition and expression of new genetic information. According to this theory 
malignant transformation would not be accompanied by the expression of neoantigens but rather by quantitative and/or distributional changes in normal (including fetal) antigens. These changes might be the result of alterations on the transcriptional, translational or posttranslational level of protein synthesis.

Because most if not all (plasma cells, T lymphocytes) of the somatic cells of an individual are genetically equal malignant transformation of a cell can result in expression of genes far deviated from what is observed in normal cells. This is demonstrated by the extensively studied expression of the intermediate filament protein family. The expression of different intermediate filament proteins has been demonstrated to parallel established principles of embryonic development and classical histology $(30,31)$. These findings led to the suggestion that intermediate filament protein expression can provide information useful in tumor diagnosis and determination of tumor histogenesis (30). Indeed intermediate filament proteins appeared to be quite valuable in this respect, but this value is somewhat limited by the occurrence of tumor cells which do not express or conversely co-express 2 or 3 different intermediate filament proteins, which in the corresponding normal cells are cell type specific (32). From these observations it can be anticipated that not the unique expression of a neo-antigen but rather aberrant levels, or patterns of expression or combinations, of normal cellular constituents might approximate the described goal of tumor specificity. Exploration of this possibility and its potential value would require elaborate studies on the expression of well defined antigens on large series of tumors with sufficiently long patient follow-up.

What could be the value of the determination of ADCP in tumors in this perspective? Neither the absence of ADCP - contrary to what has been postulated by others (33) - nor the presence of ADCP in neoplastic cells is in any way tumor specific (17, 33-39). Expression of ADCP is not tissue nor cell type specific (18) and therefore its presence in metastatic lesions does not provide clues with regard to the origin of the primary tumor. In a neoplasm in a particular organ or cell system the level of expression or its subcellular distribution might be an indicator of the differentiation processes in the neoplastic cells and as such might somehow predict the biological behavior of the neoplasm. In this respect biochemical analysis of tumor extracts is of limited value because this does not provide information on the frequently observed intercellular heterogeneity within a single neoplasm $(36,38,39)$. Immunohistochemical analysis yields essential information because it provides a possibility to study antigen expression at cellular and even subcellular level.

ADCP is secreted into body fluids $(5,40-41)$, therefore quantitative ADCP determination in these fluids in patients with an ADCP producing cancer may have diagnostic value or may provide information useful for patient follow-up after treatment. Such applications can be envisioned in prostatic or renal adenocarcinomas. Because the function of ADCP is unknown, the predictive value of its cellular expression per $s e$, and its subcellular localization for the biological behavior of the tumor is speculative. The described apical membrane associated expression of ADCP in a number of normal epithelia (18) reflects normal cell polarity and epithelial cell 
polarity can be regarded as a sign of appropriate differentiation. Consequently, deviation of the normal ADCP expression pattern in tumor cells can be regarded as an indicator of a less differentiated phenotype. This was substantiated in prostatic and renal adenocarcinomas where ADCP expression patterns correlated with metastatic propensity which is generally considered to be higher in poorly differentiated cells $(39,42)$. It would be a major breakthrough if the actively proliferating and metastasizing cells in a tumor could be identified on the basis of specific patterns of antigen expression. For such purposes ADCP can hardly be considered a suitable candidate because its expression has been found to reflect a relatively high level of differentiation $(38,39)$ and absence of a marker should be regarded as insufficient for positive identification of a cell.

\subsection{Future perspectives}

As discussed in the previous paragraph in general, determination of ADCP expression in tumors and secreted body fluids will be of limited value because at best ADCP is a marker for relatively well differentiated cell populations, the biologically least harmful tumor cells. However, the observed relationship between ADCP expression and tumor grade in renal adenocarcinomas (39) and ADCP expression and metastatic propensity in prostatic adenocarcinomas (43) is potentially important. The validity of these findings should be confirmed in larger series of patients with sufficiently long follow-up. Further exploration of the role of ADCP in neoplasia requires elucidation of its function. This would involve determination of the amino acid sequence of ADCP, studies on physicochemical properties of the molecule and identification of the ADCP gene and artificial (de-) regulation of its expression under a wide range of physiological conditions in different cell types. After identification of the ADCP gene homologies to other genes with known functions can be determined. Such studies were clearly beyond the scope of this thesis. Studies on the expression of ADCP in neoplasia are not likely to provide essential new information unless the physiological function of ADCP is more clearly resolved and the regulation of its expression understood.

\subsection{References}

1. Nishihara $H$, Ishikawa S, Shinkai $K$, Akedo $H$ (1973) Multiple forms of human adenosine deaminase. II. Isolation and properties of a conversion factor from human lung. Biochim. Biophys. Acta 302: 429-442.

2. Daddona PE, Kelley WN (1980) Analysis of normal and mutant forms of human adenosine deaminase. A review. Mol. Cell Biol. 29: 91-101. 
3. Hirschhorn $R$, Beratis $N$, Rosen FS (1976) Characterization of residnal enzyme activity in fibrob. lasts from patients with adenosine deaminase deficiency and combined immunodeficiency: Evidence for a mutant enzyme. Proc. Natl. Acad. Sei. USA.: 73: 213-217.

4. Trota PP, Balis ME (1977) Enzyme wariants in normal and neoplastic intestinal mucosa. Cancer 40: 2592-2599.

5. Schrader WP, Stacy AR (1979) Immunoassay of the adenosine deaminase complexing proteins of human tissues and body fluids. J. Biol. Chem. 254: 11958-11963.

6. Trotta PP (1982) Identification of a membrane adenosine deaminase binding protein from human placenta. Biochemistry 21: 4014-4023.

7. Chechik BE, Baumal R, Sengupta S (1.983) Localization and identity of adenosine deaminasepositive cells in tissues of young rat and calf. Histochem. J. 15: 373-387.

8. Schrader WP, Bryer PJ (1982) Characterization of an insoluble adenosine deaminase complexing protein from human kidney. Arch. Biochem. Biophys. 215: 107-115.

9. Reed LJ, Cox DJ. Multienzyme complexes. In: The Enzymes (Boyer PD, Ed.), vol. 1, Academic Press, New York, 1970, pp. 213-240.

10. Harb J, Meflah K, Duflos Y, Bernard S (1983) Purification and properties of bovine liver plasma membrane 5' nucleotidase. Eur. J. Biochen. 137: 131-138.

11. Thompson LF, Ruedi JM, Low MG (1987) Purification of $5^{5}$-nucleotidase from human placenta after release from plasma membranes by phosphatidylinositol-specific phospholipase C. Biochen. Biophys. Res. Comm. 145: 118-125.

12. Ey PL, Prowse SJ, Jenkin CR (1978) Isolation of pure IgGI, IgG2a and IgG2b immunoglobulins from mouse serum using Protein A-Sepharose. Immunochemistry 15: 429-435.

13. Schrader WP, West CA, Strominger NL (1987) Localization of adenosine deaminase and adenosine deaminase complexing protein in rabbit brain. J. Histochem. Cytochem. 35: 443-45I.

14. Andy RJ, Kornfeld R (1982) The adenosine deaminase binding protein of human skin fibroblasts is located on the cell surface. J. Biol. Chem. 257: 7922-7925.

15. Sehrader WP, West CA (1985) Adenosine deaminase complexing proteins are localized in exocrine glands of the rabbit. J. Histochem. Cytochem. 33:508-51.4.

16. Thompson RE, Hewitt CR, Piper DJ, Hansen WP, Rubin RH, Tolkoff-Rubin NE, Barrett MC, Nelles MJ (1985) Competitive idiotype-anti-idiotype immunoassay for adenosine deaminase binding protein in urine. Clin. Chem. 31: 1833-1837.

17. Herbschleb-Voogt E, ten Kate J, Meerat Khan P (1983) Adenosine deaminase complexing protein (ADCP): A transformation sensitive protein with potentials of a cancer marker. Anticancer Res. 3: 95.100 .

18. Dinjens WNM, ten Kate J, van der Linden EPM, Wijnen JT, Meera Khan P, Bosman FT. Distribution of adenosine deaminase complexing protein (ADCP) in human tissues. Submitted for publication (This thesis Chapter 4).

19. Inwood M, Povey S, Deltanty JDA (1980) Comparison of isozymes in fetal, adult and transformed fibroblasts. Cell Biol. Int. Rep. 4: 327-335.

20. Rutzky LP, Siciliano MJ (1982) Various isozyme gene expression patterns anong human coloredal carcinoma cell lines and tissues. J. Natl. Cancer Inst. 68: 81-90.

21. Wright WC, Daniels WP, Fogh J (1981) Distinction of seventy-one cultured human tumor cell tines by polymorphic enzyme analysis. J. Natl. Cancer Inst. 66: 239-247.

22. Ten Kate 1. Adenosine deaminase complexing protein as a marker in cancer studies. Academic thesis, University of Leiden, 1985.

23. Köhler $\mathrm{G}$, Milstein $\mathrm{C}$ (1975) Continuous culture of fused cells secreting antibodies of predefined specificity. Nature 256: $495-497$. 
24. Ehrlich $P$ (906) Collected studies in immunity. John Wiley and Sons, New York, 441-442.

25. Duesberg PH (1985) Acrivaled pro-onc genes: sufficient or necessary for cancer? Science 228: 669.677.

26. Weiss R, Teich N, Varmus H, Collin J. Tumor wiruses. Cold Spring Harbor Press, Cold Spring Harbor, New York, 1985.

27. Duesberg PH (1983) Retrovial transformation genes in normal cells? Nature 304: 219-225.

28. Duesberg PH (1987) Retroviruses as carcinogens and pathogens: expectations and reality. Cancer Res. 47:1199-1220.

29. Cleary ML, Smith SD, Sklar 1 (1986) Cloning and structural analysis of cDNA"s for bcl-2 and a hybrid bel-2/immenoglobulin transeript resulting from the $1(14 ; 18)$ translocation. Cell 47 : 19.28.

30. Osborn M, Weber K (1986) Intermediate fiament proteins: a multigene family distingushing major cell lineages. Trends Biochem. Sci. 11: 469-472.

31. Steinert PM, Steven AC, Roop DR (1985) The molecular biollogy of intermediate filaments. Cell 42: 411419 .

32. Gould VE (1985) The coexpression of distinct classes of intermediate filaments in human neoplasns. Arch. Pathol. Lab. Med. 109: 984-985.

33. Trotta PP, Balis ME (1978) Characterization of adenosine deaminase from normal colon and colon tumors. Evidence for tumor specific wariants. Biochemistry 17: 270-278.

34. Ten Kate J, Wijnen JT, Boldewijn J, Meera Khan P, Bosman FT (1985) Immunohistochemical localization of adenosine deaminase complexing protein (ADCP) in intestinal mucosa and in colorectal adenocarcinoma as a marker for tumour cell heterogeneity. Histochem. J. 17: 23-31.

35. Ten Kate J, Wijnen JT, Herbschleb-Voogt E, Girffioen G, Bosman F T, Meera Khan P. Specific isozyme profiles of adenosine deamirase in colorectal adenocarcinoma. In: Selected topics in clinical enzynology (Goldberg D and Werner M, Eds.), Walter de Gruyter, New York, 1983, pp. 11-27.

36. Ten Kate J, Wijnen JT, van der Goes RGM, Quadt R, Griffioen G, Bosman FT, Meera Khan P (1984) Quantitative changes in adenosine deaminase isozymes in human colorectal adenocarcinomas. Cancer Res. 44: 4688 4692.

37. Ten Kate J, Beukers J, van der Goes RGM, Winnen JT, Romijn J, Griffioen G, Bosman FT, Meera Khan P. Adenosine deaminase complexing protein $(\mathrm{ADCP})$ : a transformation sensitiwe marker and a possible tool in immunodiagnostics of solid tumors. In: Proc. I colloquium Protides Biol. Fluids (Peeters H, Ed.), Pergamon Press, Oxford, 1984, pp. 355-358.

38. Ten Kate J, van den Ingh HFGM, Meera Khan P, Bosman FT (1986) Adenosine deaminase complexing protein (ADCP) immunoreactivity in colorectal carcinoma. Int. J. Cancer 37:479-485.

39. Dinjens WNM, wan der Linden EPM, Lenders MHJH, ten Kate J Meera Khan P, Bosman FT. Adenosine deaminase complexing protein (ADCP) immunoreactivity in adenocarcinomas. Submitted for publication (This thesis Chapter 6).

40. Schrader WP, Woodward FJ "Pollara B (1979) Purification of an adenosine deaminase complexing protein from human plasma. I. Biol. Chem. 254: 11964-11968.

41. Thompson RE, Piper DJ, Galberg C, Chan TH, Tolkoff-Rubin NF, Rubin RH (1985) Adenosine reaminatse binding protein, a new diagnostic marker for kidney disease. Clin. Chem. 31: 679-683.

42. Dinjens WNM, ven Kate J, Kirch JAJM, van der Linden EPM, Tanke H, Jonas $U$, van den Ingh HFOM. Meera Khan P, Bosman FT. ADCP expression in prostatic adenocarcinomas. Submitted for publication (This thesis Chapter 7). 


\section{Summary}

This thesis focusses on the distribution of the adenosine deaminase complexing protein (ADCP) in normal and neoplastic cells. In CHAPTER $\mathbb{t}$ the properties of the protein and its possible behavior during malignant transformation are discussed. Some of the reviewed data indicate that the expression of ADCP might be specifically altered during malignant transformation. It has been suggested that ADCP can be used as a marker in studies on cellular differentiation and tumor classification. Studies to this end require the availability of specific antibodies which would allow the qualitative determination of ADCP in tissue sections by immunohistochemistry and the quantitative determination of $A D C P$ in tissue homogenates by radioimmunoassay (RIA). These methods require the availability of highly specific antiADCP antibodies.

In CHAPTER 2 a method is described for the generation of antibodies against minute amounts of ADCP. The method is based on the adsorption of ADCP to a solid phase (nitrocellulose membrane) and the subsequent implantation of this protein-coated membrane in a mouse. This procedure resulted in high serum antibody titers against native ADCP. In some experiments we used a polyvinylidene difluoride (PVDF) membrane. In order to generate antibodies which would allow the detection of ADCP in routinely fixed and processed tissues, PVDF membranes carrying ADCP were fixed and processed according to routine tissue processing protocols before implantation. This procedure resulted in the generation of antisera which allowed the detection of ADCP in routinely processed tissues. For the generation of monoclonal antibodies the immunized mice received booster injections with higher quantities of impure ADCP preparations, unfixed or after fixation and processing. With this procedure a panel of ADCP reactive monoclonal antibodies was obtained.

It has been suggested that mouse and rat lack ADCP because in these species exclusively the small molecular weight form of adenosine deaminase (ADA-S) is found. This suggestion is based on the assumption that the ADA binding capacity is an inherent functional characteristic of ADCP. CHAPTER 3 reports on the presence of $A D C P$ immunoreactivity in mouse and rat determined with a species cross-reactive polyclonal anti-ADCP serum. In the mouse the tissue and subcellular distribution and the electrophoretic mobility in starch and polyacrylamide gels of the protein correspond with those of ADCP but it does not bind ADA-S. It is suggested that the function of ADCP is not ADA-related.

In CHAPTER 4 studies concerning the distribution of ADCP in the human body are described. This was investigated quantitatively by ADCP specific RIA of soluble and plasma membrane fractions and qualitatively by immunohistochemistry. In these studies a specific rabbit anti-human ADCP antiserum was used. In 18 investigated tissues ADCP was found in the soluble as well as in the membrane fractions. In all tissues the membrane fractions contained more ADCP than the soluble frac- 
tions. ADCP immunoreactivity was found predominantly in exocrine glands and absorptive epithelia especially at the secretory or absorptive apex of the cell. This led to the suggestion that the function of $A D C P$ is related to the secretory and absorptive processes.

Because of the important role of ADA in human T-lymphoid differentiation the presence of ADA and ADCP on human T-lymphoid cells was studied, as described in CHAPTER 5 . Of all investigated T-lymphoid cells about $18 \%$ expressed membrane ADA. Membrane ADCP expression was demonstrated on 47\% and 14\% of the peripheral blood T-lymphocytes (PBL-T) and thymocytes (anti-CD5 positive) respectively. The $T$-helper/inducer (anti-CD4 positive) and T-cytotoxic/suppressor (anti-CD 8 positive) subpopulations contained $55 \%$ and $28 \%$ membrane ADCP positive cells respectively. When the PBL-T were incubated with a lysate of human erythrocytes (as source of ADA-S) about $50 \%$ of the cells was found to display ADA at the membrane. It is likely, that ADA-S binds to membrane associated ADCP.

In CHAPTER 6 the ADCP expression in various normal and neoplastic human tissues is described. In these studies a polyclonal anti-ADCP antiserum and 2 ADCP reactive monoclonal antibodies (1071 and 1072) were used. The reactivity patterns of the 2 monoclonal antibodies did not completely match the patterns observed with the polyclonal antiserum. This finding might imply more molecular heterogeneity of ADCP than hitherto known. The patterns of expression of ADCP in renal cell carcinomas were found to correlate with the stage of the tumor. The patterns of staining in various other carcinomas suggested that ADCP might be an additional parameter in the assessment of the histogenesis and degree of differentiation of neoplastic cells but with limited significance.

A more detailed study of ADCP expression in human prostatic adenocarcinomas is described in CHAPTER 7. The anti-ADCP antiserum showed 4 distinct staining patterns: diffuse cytoplasmic, membranous, both cytoplasmic and membranous and no ADCP expression. When a membranous staining pattern was observed no metastases were found, whereas metastases occurred only in cases with no or only cytoplasmic ADCP staining. This suggests that immunohistochemical detection of ADCP might predict the biological behavior of prostatic cancer. However, the occurrence of membrane ADCP staining in the xenograft of a cell line derived from a prostatic carcinoma metastasis indicates that this is not an absolute fact.

The results of studies concerning the relationship between ADCP expression and intestinal epithelial cell differentiation are reported in CHAPTER 8. Because in the digestive tract ADCP expression occurs only in absorptive enterocytes its pattern of expression was compared with those of villin and sucrase-isomaltase, two highly specific markers for enterocytic differentiation. As model system 4 human colorectal carcinoma derived cell lines were used, grown in vivo and in witro under differentiation modulating conditions. Villin expression was almost always found in combination with membranous ADCP expression whereas ADCP expression also occurred without villin expression. Sucrase-isomaltase expression was also found in 
combination with villin. The strongest membrane ADCP reactivity was observed in well differentiated cells, but usually in combination with cytoplasmic reactivity. Because cytoplasmic $A D C P$ reactivity was not observed in normal enterocytes this cytoplasmic ADCP reactivity is probably a hallmark of incomplete enterocytic differentiation. It is suggested that expression patterns of villin, sucrase-isomaltase and ADCP might represent different levels of enterocytic differentiation.

Finally, in CHAPTER 9 the possible physiological function of ADCP and its role in understanding the process of neoplastic transformation are discussed. Considerations on future perspectives for $\mathrm{ADCP}$ research conclude this chapter. 


\section{Samenvatting}

In dit proefschrift zijn de resultaten van onderzoek naar het vóorkomen van het adenosine deaminase complexerend proteine (ADCP) in normale en neoplastische cellen beschreven.

In HOOFDSTUK 1 wordt een overzicht gegeven van de relevante literatuur betreffende ADCP. Uit dit overzicht blijkt dat het expressie patroon van ADCP in cellen mogelijk verandert tijdens maligne ontaarding. In de literatuur wordt tevens gesuggereerd dat de expressie van ADCP gebruikt kan worden als een merker voor cellulaire differentiatie en tumor classificatie. Dit zou onderzocht kunnen worden met behulp van antilichamen die ADCP specifiek kunnen aantonen. Met deze antilichamen kan ADCP zichtbaar worden gemaakt in weefselcoupes met behulp van immunohistochemische technieken. Tevens kan ADCP kwantitatief worden bepaald in weefsel homogenaten door middel van radioimmunoassay (RIA).

In HOOFDSTUK 2 wordt een procedure beschreven waarmee polyclonale en monoclonale antilichamen kunnen worden verkregen wanneer slechts zeer kleine (nanogram) hoeveelheden ADCP beschikbaar zijn. Deze methode is gebaseerd op de binding van $A D C P$ aan een vaste drager (nitrocellullose membraan) waarna deze drager wordt geimplanteerd in een muis. $\mathrm{Na}$ immunisatie van muizen met nanogram hoeveelheden (natief) ADCP gebonden aan een nitrocellulose membraan werden antisera verkregen die reageren met natief $A D C P$. In een aantal experimenten werd als vaste drager een polyvinylideen difluoride (PVDF) membraan gebruikt. Na binding van $\mathrm{ADCP}$ en vóór implantatie werd het PVDF membraan behandeld overeenkomstig de procedure die weefsel routinematig ondergaat vóór toepassing van de immunohistochemische techniek (dat wil zeggen fixatie met formaline, insluiten in paraffine, ontparaffineren en remmen van de endogene peroxidase activiteit). $\mathrm{Na}$ toepassing van deze procedure werden antisera verkregen waarmee ADCP aangetoond kan worden in routinematig behandelde weefselstukjes afkomstig van nier, prostaat en dunne darm. Ter verkrijging van monoclonale antilichamen kregen de geimmuniseerde muizen extra injecties met homogenaten van weefsel dat ADCP bevat. Deze procedure leverde een aantal monoclonale antilichamen op die met ADCP reageren.

In de literatuur is gesuggereerd dat muizen en ratten geen ADCP bezitten omdat uit biochemische experimenten bleek, dat in deze diersoorten geen vorm met een hoog molecuulgewicht van het enzym adenosine deaminase (ADA-L) aanwezig is. Deze suggestie is gebaseerd op de veronderstelling dat binding van de vorm met een laag molecuulgewicht van adenosine deaminase (ADA-S) door ADCP een functionele en inherente eigenschap van $A D C P$ is. In HOOFDSTUK 3 worden experimentele resultaten beschreven die aantonen dat in muizen en ratten een $A D C P$ immunoreactief eiwit vóórkomt. Zowel de weefsel- en subcellulaire distributie als de electroforetische mobiliteit in zetmeel en polyacrylamide gels van dit eiwit komen nauw overeen met die van $A D C P$. Echter, dit ADCP immunoreactief eiwit vertoont geen affiniteit 
voor ADA. Geponeerd wordt dat deze bevinding een aanwijzing is voor een fysiologische functie van ADCP die niet gerelateerd is aan $A D A$.

De resultaten van experimenten naar de expressie van $\mathrm{ADCP}$ in normale humane weefsels zijn beschreven in HOOFDSTUK 4. Met behulp van een specifiek konijne anti-humaan ADCP antiserum is ADCP kwantitatief aangetoond met een RIA en kwalitatief met de immunoperoxidase techniek. Met de RIA werd ADCP gevonden zowel in de cytosol- als de membraanfracties van de onderzochte weefsels. In elk weefsel werd meer ADCP (per milligram eiwit) gevonden in de membraanfractie dan in de corresponderende cytosolfractie. Dat ADCP voornamelijk membraan geassocieerd vóórkomt werd bevestigd door de resultaten van de immunohistochemische studies. De bevinding dat ADCP met name werd gevonden in het secretoir of resorptief gedeelte van de cellen van exocriene klieren en resorptieve epithelen leidde tot de suggestie dat ADCP een secretie of resorptie geassocieerd eiwit is.

Het enzym ADA speelt een belangrijke rol bij de differentiatie van $T$ lymfocyten. Daarom werd het vóórkomen van ADA en ADCP op intakte humane T-lymfoïde cellen bestudeerd. De resultaten van deze flowcytometrische studie zijn beschreven in HOOFDSTUK 5. Uit perifeer bloed werden de totale T-lymfocyten populatie (anti-CD5 positief) en de T-helper/inducer (anti-CD4 positief) en T-cytotoxic/suppressor (anti-CD8 positief) subpopulaties onderzocht. Tevens werden thymocyten onderzocht. In elke onderzochte subpopulatie bleek ongeveer $18 \%$ van de cellen membraan geassocieerd ADA te bezitten. Membraan geassocieerd ADCP werd gevonden in $55 \%$ van de $\mathrm{T}$-helper/inducer cellen, in $28 \%$ van de $\mathrm{T}$-cytotoxic/suppressor cellen en in $14 \%$ van de thymocyten (anti-CD5 positief). In de totale T-lymfocyten populatie van het perifere bloed bleek $47 \%$ van de cellen membraan geassocieerd ADCP te bezitten. Na incubatie van deze populatie met een lysaat van humane erythrocyten (als bron van humaan ADA-S) werd op ongeveer $50 \%$ van de cellen ADA aangetoond. Deze bevinding leidde tot de veronderstelling dat dit ADA-S gebonden is aan membraan geassocieerd ADCP.

In HOOFDSTUK 6 worden de resultaten beschreven van immunohistochemische ADCP bepalingen in een aantal normale en neoplastische humane weefsels. In deze studies werd gebruik gemaakt van een konijne polyclonaal anti-ADCP antiserum en twee met $\mathrm{ADCP}$ reagerende muize monoclonale antilichamen. De reactiviteitspatronen van de twee monoclonale antilichamen komen niet volledig overeen met het reactiviteitspatroon van het polyclonale antiserum. Deze bevinding duidt wellicht op, tot nu toe onbekende, moleculaire heterogeniteit van ADCP. In een kleine serie niertumoren werd gevonden dat de ADCP expressiepatronen correleren met de stagering van de tumoren. Gesuggereerd wordt dat dit mogelijk wijst op een relatie tussen de ADCP expressiepatronen en het biologisch gedrag van de niertumoren. Bepaling van de ADCP expressiepatronen in andere tumoren leidde tot de veronderstelling dat deze patronen parameters kunnen zijn voor bepaling van de histogenese en mate van differentiatie van epitheliale tumoren.

In HOOFDSTUK 7 wordt beschreven dat in prostaattumoren een relatie werd gevonden tussen de ADCP expressiepatronen en de aanwezigheid van metastasen. 
Geen metastasen werden gevonden wanneer de primaire tumor, zoals normaal prostaatweefsel, membraan geassocieerde ADCP immunoreactiviteit vertoonde. Metastasen werden uitsluitend gevonden in patiënten waarbij in de primaire prostaattumor ADCP diffuus in het cytoplasma of niet werd aangetoond. Uit deze resultaten werd geconcludeerd dat de immunohistochemische $\mathrm{ADCP}$ bepaling in prostaattumoren van belang kan zijn voor de voorspelling van het biologisch gedrag van de tumor.

HOOFDSTUK 8 behandelt een onderzoek naar de relatie tussen ADCP expressie en de differentiatie van enterocyten. De expressiepatronen van ADCP werden vergeleken met de expressiepatronen van de eiwitten villine en sucrase-isomaltase, twee merkers voor enterocytaire differentiatie. Omdat een aantal colorectale tumorcellijnen geïnduceerd kan worden tot enterocytaire differentiatie zijn vier humane colorectale tumorcellijnen (HT-29, Caco-2, 5583-E, 5583-S) als model gebruikt. Deze werden gekweekt in vivo als xenotransplantaat en in vitro onder een aantal differentiatie modulerende omstandigheden. Op één uitzondering na werd villine steeds in combinatie met membraan gebonden ADCP expressie gevonden, doch ADCP kon tevens worden aangetoond in afwezigheid van villine expressie. Sucrase-isomaltase werd uitsluitend aangetoond in combinatie met villine. De sterkste membraangebonden ADCP immunoreactiviteit werd gevonden in goed gedifferentieerde cellen, echter meestal in combinatie met cytoplasmatische reactiviteit. In normale darmepitheelcellen werd nooit ADCP in het cytoplasma aangetoond. Wellicht wijst deze cytoplasmatische ADCP expressie op niet volledig voltooide enterocytaire differentiatie. Gesuggereerd wordt dat expressie patronen van villine, sucrase-isomaltase en ADCP verschillende differentiatie niveau's in de enterocytaire differentiatie vertegenwoordigen.

In HOOFDSTUK 9 wordt gespeculeerd over de fysiologische functie van ADCP en over de waarde van de bepaling van $\mathrm{ADCP}$ en andere antigenen in het algemeen voor het vergroten van het inzicht in het proces van neoplastische transformatie. Het proefschrift eindigt met een aantal overwegingen voor verder onderzoek aan het eiwit ADCP. 


\section{Dankwoord}

Bij de totstandkoming van dit proefschrift ben ik dank verschuldigd aan velen. In de eerste plaats dank ik mijn ouders, dat ze mij de gelegenheid hebben geboden om te studeren. Zij en mijn oma hebben mij gestimuleerd en mijn studie met belangstelling gevolgd. Ik betreur het zeer dat mijn vader en mijn oma het verschijnen van dit proefschrift niet meer meemaken.

De bijdragen van Prof.dr. F.T. Bosman aan dit proefschrift zijn onontbeerlijk geweest. Beste Fré, jouw kennis van zaken, enthousiasme en optimisme waren voor mij uitermate inspirerend. De wijze waarop en de snelheid wararmee jij de manuscripten corrigeerde hebben mij gestimuleerd. Jouw adagium "Het komt wel goed" heeft zelfs op een Maastrichtenaar indruk gemaakt.

Dr. J. ten Kate, beste Joop. Jij hebt niet alleen de basis gelegd voor het onderzoek, beschreven in dit proefschrift, maar je bent ook nauw bij de uitvoering betrokken geweest. Jouw ideeën, adviezen en suggesties met betrekking tot zowel het experimentele werk als de manuscripten hebben een essentiële bijdrage geleverd.

Het onderzoek, beschreven in dit proefschrift, is uitgevoerd in samenwerking met Prof.dr. P. Meera Khan, afdeling Anthropogenetica, Rijksuniversiteit Leiden. Beste Meera, jou dank ik voor de vrijheid die ik kreeg bij de uitvoering van het onderzoek en voor de stimulerende gesprekken die wij voerden.

Dr. Wim Zeijlemaker (afdeling Klinische Immunobiologie) en Dr. Dirk Roos (afdeling Bloedcelchemie), Centraal Laboratorium van de Bloedtransfusiedienst (CLB) van het Nederlandse Rode Kruis te Amsterdam, en Prof. dr. Chris De Bruijn, Technische Universiteit Eindhoven, dank ik voor de begeleiding van mijn voormalig onderzoek op het CLB, waar de basis is gelegd voor het in hoofdstuk 5 beschreven onderzoek.

Een groot deel van de immunohistochemische experimenten is uitgevoerd door Edith van der Linden. Beste Edith, jouw inzet en nauwgezette manier van werken hebben mij herhaaldelijk uit de onderzoeksdalen gehaald waarin ik was terecht gekomen.

De inzet van Marie-Hélène Lenders is met name in de eindfase wan het onderzoek van cruciale betekenis geweest.

Aan Juul Wijnen, afdeling Anthropogenetica, Rijksuniversiteit Leiden, ben ik dank verschuldigd voor het zuiveren van ADCP en het uitvoeren van de RIA's en de electroforetische eiwitscheidingen in zetmeel gels.

Claire Bollen en Marianne Rikers dank ik voor het snel invoeren van de manuscripten in de computer. Beste Claire en Marianne, jullie bleven onder hectische omstandigheden toch steeds perfect werk afleveren.

Caspar Signet is betrokken geweest bij de productie van de monoclonale antilichatmen. Hij en Cor Beek hebben een aantal electroforetische eiwitscheidingen nauwkeurig uitgevoerd.

Bij de fotografie en electronenmicroscopie heb ik veel hulp gehad van Paul Bomans en Marc Stuart. 
Op Birgit Engelen en Margriet Pijls heb ik nooit tevergeefs een beroep gedaan voor het snijden van weefselcoupes.

Dank ben ik verschuldigd aan de velen die weefsel voor mij hebben verzameld en ter beschikking gesteld: Sjaak Joosten, Plet op de Beek en Jacques Baltis; Drs. Jan Kirch, afdeling Urologie en Prof.dr. G.J. Fleuren, afdeling Pathologie, Rijksuniversiteit Leiden; Dr. J. Koudstaal, afdeling Pathologie en Drs. Marc Snijders, afdeling Gynaecologie, De Wever ziekenhuis, Heerlen; Dr. Harry van den Ingh, afdeling Pathologie, St. Clara ziekenhuis, Rotterdam en Dr. Gert Jan van Steenbrugge, afdeling Urologie, Erasmus Universiteit Rotterdam en Drs. Willem Rinsema, afdeling Algemene Heelkunde, Academisch Ziekenhuis, Maastricht.

Dr. Hans Tanke en Drs. Paul Oljans, afdeling Histochemie en Cytochemie, Rijksuniversiteit Leiden, zijn behulpzaam geweest bij de uitvoering van de flowcytometrische bepalingen beschreven in hoofdstuk 5 .

Dr. H.P. Hauri, Biozentrum der Universität Basel, danke ich herzlich für das zur Verfügungstellen von anti-Sucrase-Isomaltase monoklonalen Antikörpern.

Van Peter Dormans, vakgroep Medische Microbiologie, kreeg ik waardevolle adviezen voor de uitvoering van de immunoprecipitatie experimenten.

Drs. Adriaan de Bruïne dank ik voor het graderen van de prostaattumoren.

De medewerkers van de dienst Centrale Proefdier Voorziening, met name Frans Weekers, Eep van Dam en Peter Kelderman dank ik voor de assistentie bij het werk met proefdieren.

Prof.dr. G.H. Blijham, Prof.dr. J. Drukker, Prof.dr. F. ten Hoor, Prof.dr. C.H.M.M. De Bruijn (Technische Universiteit Eindhoven) en Prof.dr. D.J. Ruiter (Katholieke Universiteit Nijmegen) ben ik erkentelijk voor de beoordeling van dit proefschrift.

Lucia Geurts en Dr. Ton de Goeij dank ik voor de correctie van de Nederlandse teksten.

Alle medewerk(st)ers van de vakgroep Pathologie en de in het Biomedisch Centrum werkzaam zijnde leden van de vakgroep Interne Geneeskunde dank ik voor de fijne en collegiale sfeer waarin mijn onderzoek heeft plaatsgevonden.

Lieve Juliètte, jouw steun en geduld waren onontbeerlijk. 


\section{Curriculum vitae}

Winand Dinjens werd op 13 januari 1956 geboren te Maastricht. Vanaf 1968 tot 1975 bezocht hij het Henric van Veldeke-College in Maastricht. Hier behaalde hij in 1973 het diploma HAVO en in 1975 het diploma Atheneum B. In 1975 begon hij met de studie Biologie aan de Katholieke Universiteit Nijmegen en behaalde in december 1978 het kandidaatsexamen B1g. In april 1982 legde hij het doctoraalexamen af met als hoofdvak Zoölogie II (Dierfysiologie, onder leiding van Prof.dr. S.E. Wendelaar Bonga) en als bijvakken Anthropogenetica (onder leiding van Prof.dr. C.H.M.M. De Bruijn) en Zoölogie I (Ontwikkelingsbiologie der dieren, onder leiding van Prof.dr. J.M. Denucé en Prof. dr. C.H.M.M. De Bruijn). Tevens behaalde hij onderwijsbevoegdheid in Biologie. Vanaf mei 1982 tot juni 1985 was hij werkzaam binnen een FUNGO project dat werd uitgevoerd op de afdeling Klinische Immunobiologie van het Centraal Laboratorium van de Bloedtransfusiedienst van het Nederlandse Rode Kruis te Amsterdam (onder leiding van Dr. W.P. Zeijlemaker) en op het Anthropogenetisch Instituut van de Katholieke Universiteit Nijmegen (onder leiding van Prof.dr. C.H.M.M. De Bruijn).

Sinds augustus 1985 verricht hij onderzoek in het kader van een KWF project bij de afdeling Pathologie van de Rijksuniversiteit Limburg te Maastricht (onder leiding van Prof.dr. F.T. Bosman). 